的絶び氐昏服宪 界對近人到必段 । 體表年ギ會要階口 制義の、川性賛 の 觀論村絕濟說 絕 點占對過妿初對

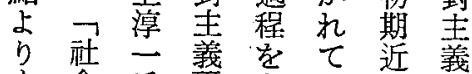
す會氏研过代の 总的の究預 吕國矢 柴結意野示家質

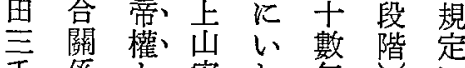
平係亡安次等监 雄 ᄂ 領敏てがと關 氏の 敖氏 $の$ た し

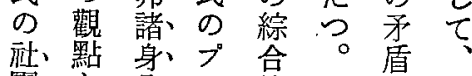

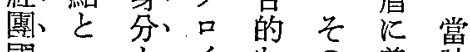
國次とイなの着該 家、社 の、七 後目時 論、團 構、ソラ及代 等合浩、官 ン び れ のの的僚スそた部 重歷連制絕れ成曾 要 象關、1 對 な的を軍主相治經 䃟意中制制前民沿 究義核研論後に史 議評据究我占的 䜟價据石染 加と部治同身規

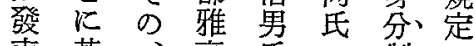
表基、亮氐 の 制 さづあ氏 の-\|封 柆 たのフ連 等 建 三 概 プラの 族制 絕 宮念口ン包制の 對宏象 1 括の最 圭芝的七官的觀終 義 氏考ン瘖な點 段 認察般研諸古階

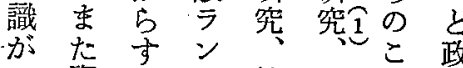
二資る篠中心治 屡本 ド法塚木矛" 深圭

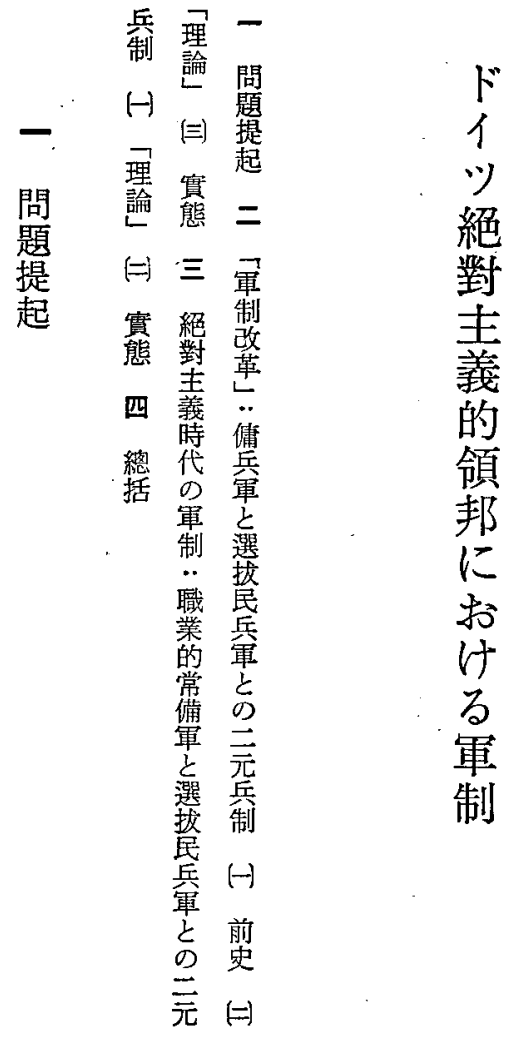




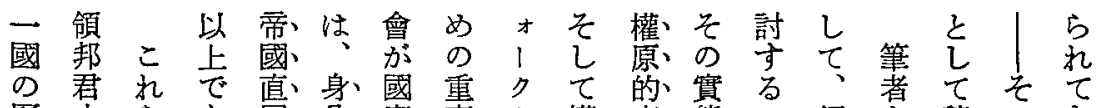

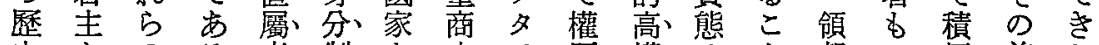

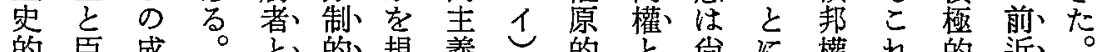
的臣成。之的規 義 發民果 穴抵定的こ高公的よ迄に代々

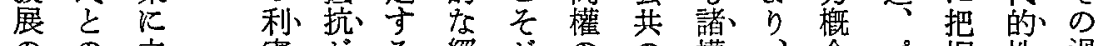
のの 立害方る 經肪の の 權、念 $フ$ 握性過 基支っ 調よ 近濟、、中酔原以以念口势 格、程

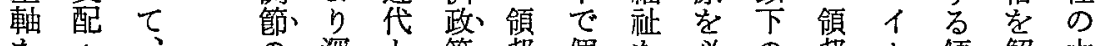

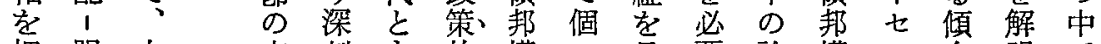

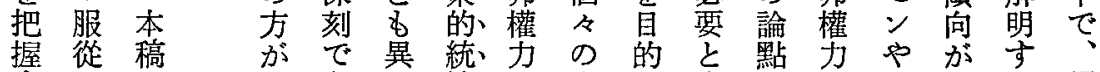
握行模

万 基 は

に本、

際 的

乙 構 リ

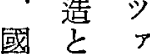

內

的關亡

契 連 並

穖でん

壳皆

重考

寸 察 高

当祭權

余るを

りこ構

之成

本江 $L$

來 した

對た軍、

外以事

的 ○權、

契 戰 办

機 後妾

に 我

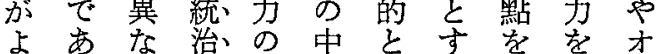

りつる 權一間する 明正

深た恒を 基、權る個ら䈏 ス

强 る 絕

刻閉常核礎力排別少化卜て亦義

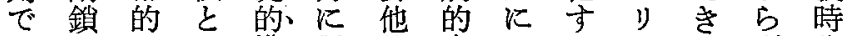

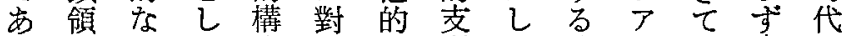

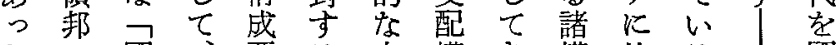

たっ國っ要る中、權き權比る 國

非 节家 司素 特核の た原

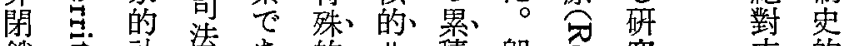

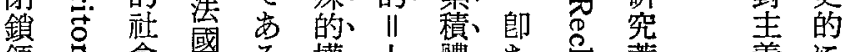

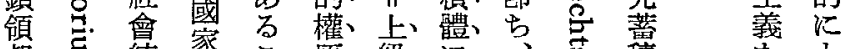

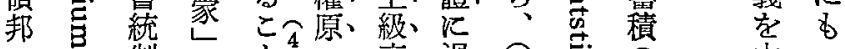

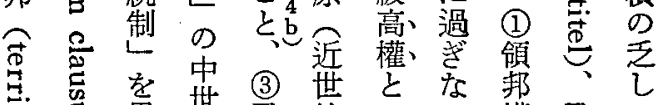

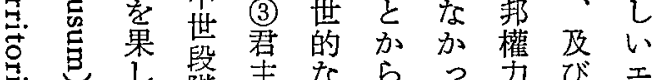

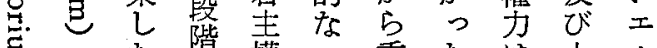

当とた嚾 一重たは上ル

马當、と

止 加 領

ま國 邦、

りの 國

得西制

な洋と

小史

軍學 關

制界 連

迄でで

方注

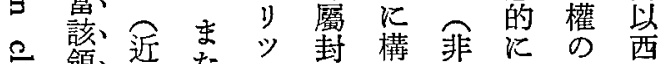

辛領世近 た

中

品、的或 1 權さ近括 $の$ 絕

志队、家に㫗れ代的內 對

世近

近

代で

とは

のな

間

江 沂

置 近

道

特、と

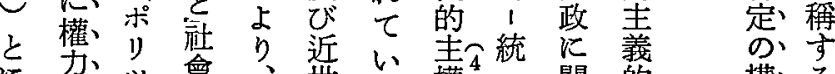

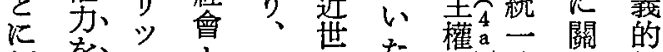

等、る

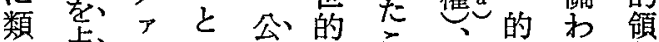

造、傾

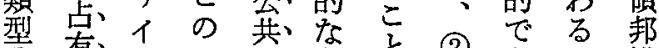

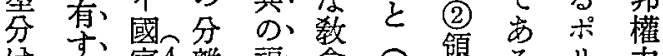

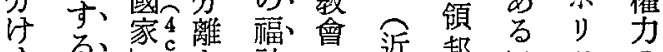

を向

有、之

寸、軌

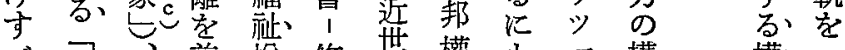

き 外、 (4) 提 進、道的權名

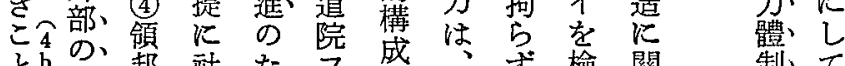

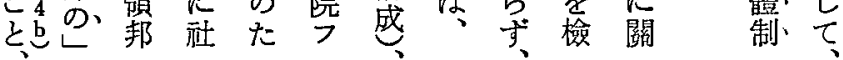


統 $\%$ 想圭族治置分的核に年初段る義輕

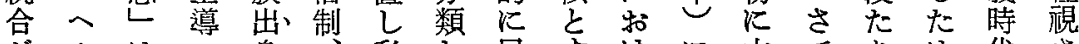
がルは、身、私し民卞けに本てりめ代さ 果 1 消監の墥企た兵るる挌、得ののれ さ農 隇督將、會業。的レ部い的軍る物大過

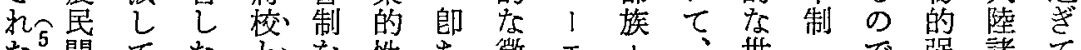
た点間てたとを性ち徵エ1、世强諸て

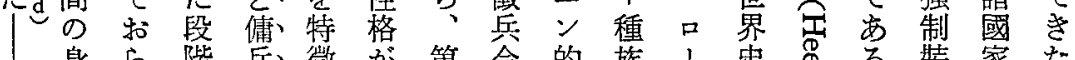

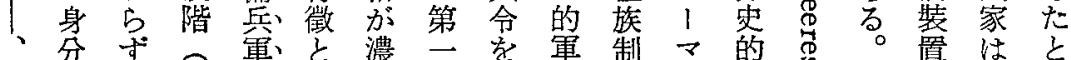

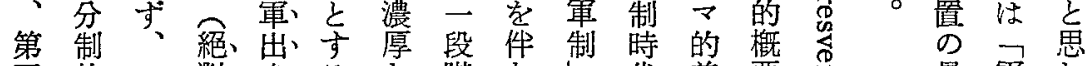
至的フ對身るな階な代普要恋最軍わ

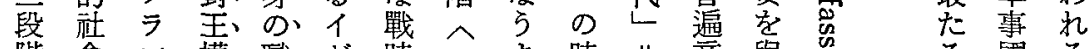
階會 ン 權、職 ギ時

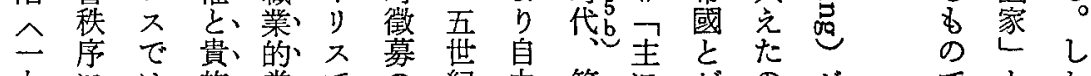

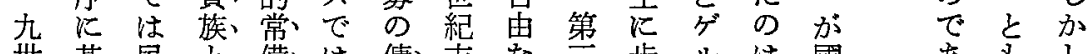

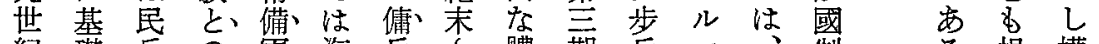

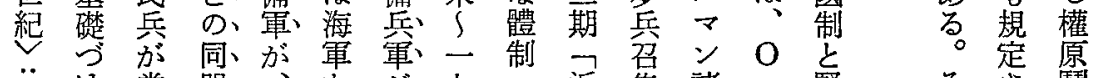

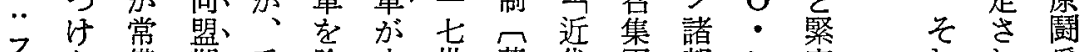

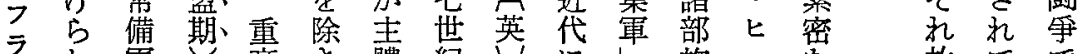

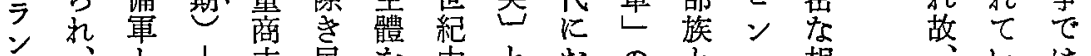

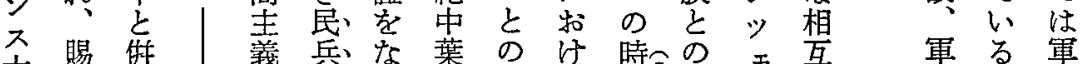

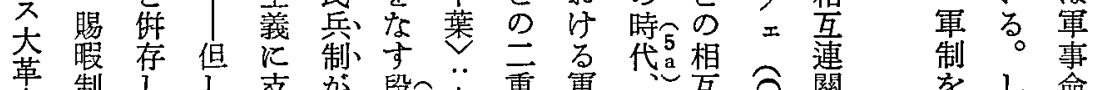

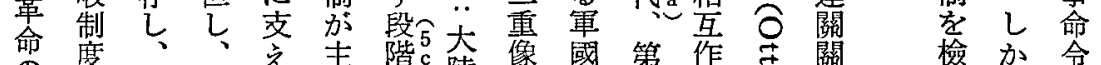

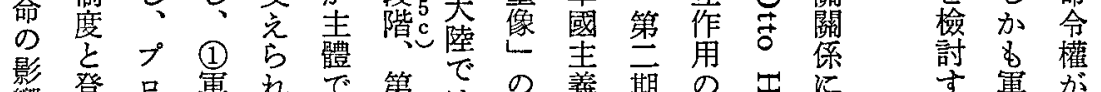

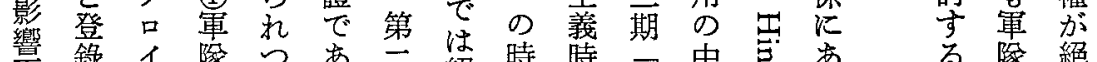

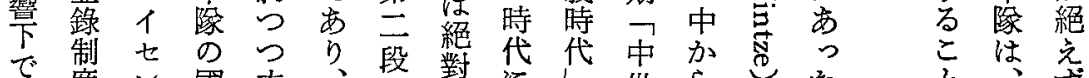

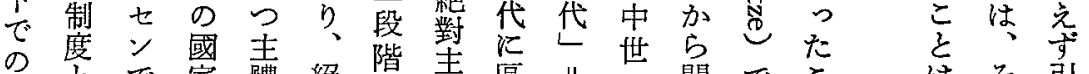
、とで家體絕陌義區川に開でこ汇て引

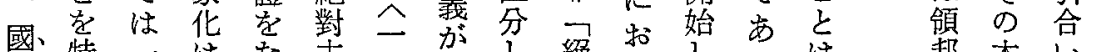
民、特二卧圭七確し絕けしっは邦本い

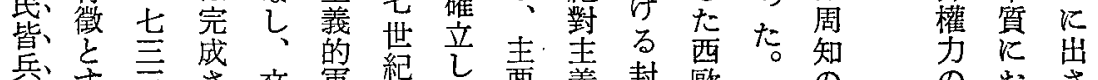
原吉至さ文軍紀て要義封歐彼の括さ

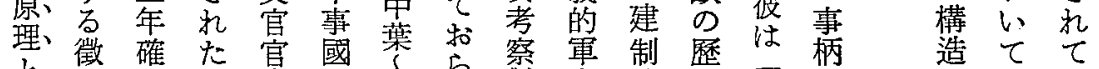

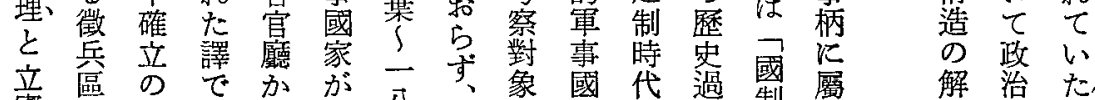

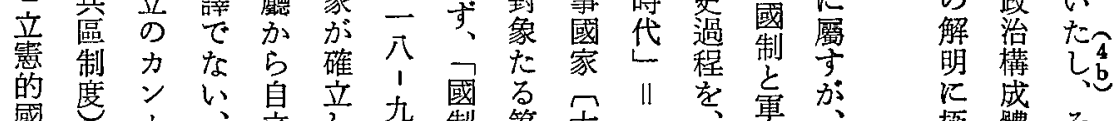

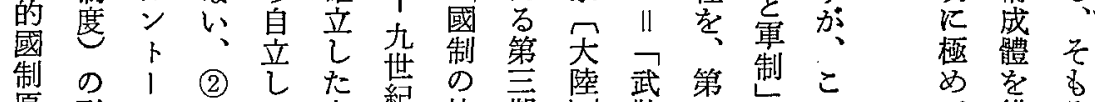
原形 理で制舊つ陸交外等々騎期二問有持字

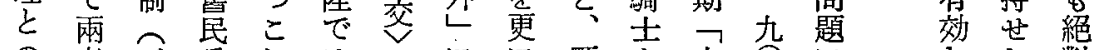

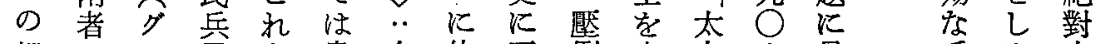
相のl惫を貴自位晋倒中古六最手め琹 


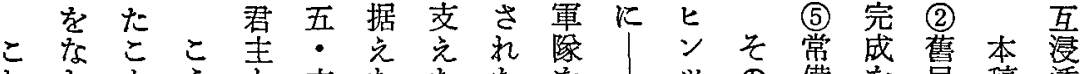

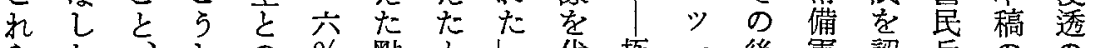
$ら た し の \%$ 點と代極後軍認兵の の

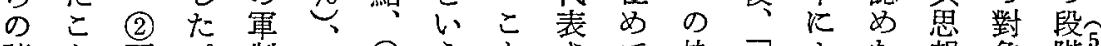

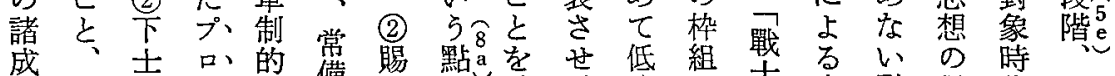

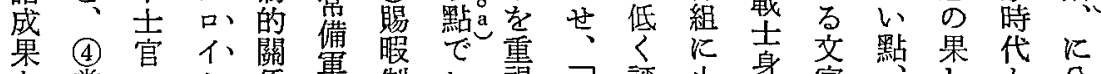

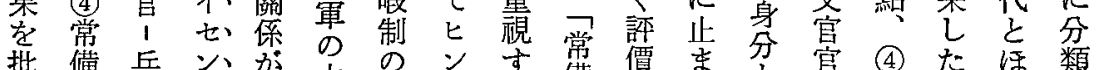

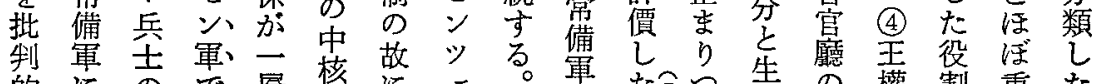
的にので層核にェ。莗だつ生の權割重た

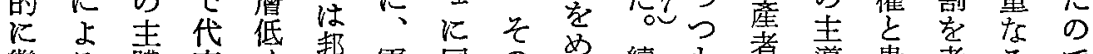
繼る 體 表く邦軍同の文續方者導貴考る で

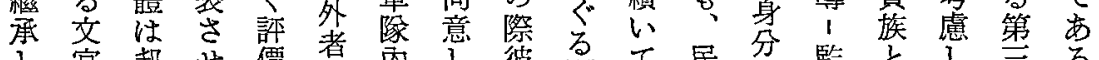
な 官 邦 せ 價 者 常、さ が䲣 者 備水業內 つ

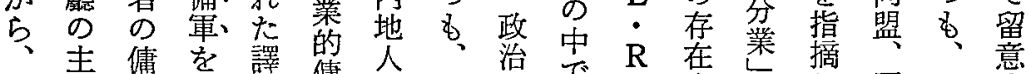

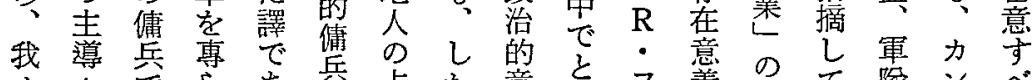

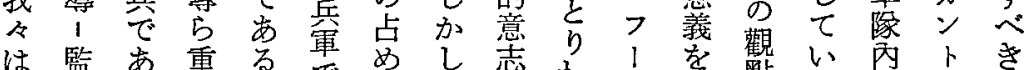

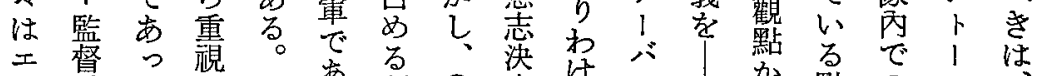

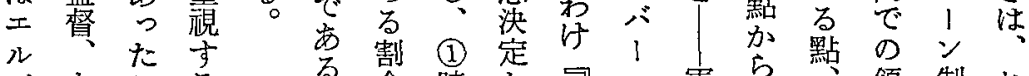

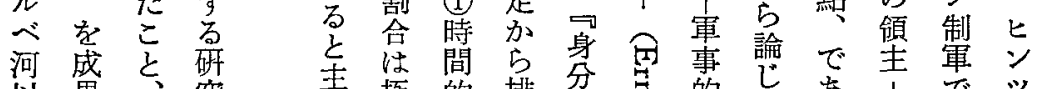

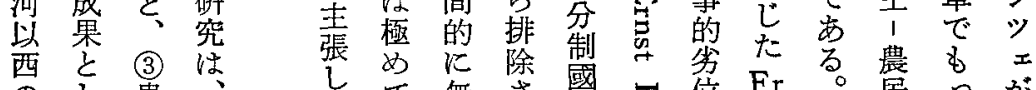

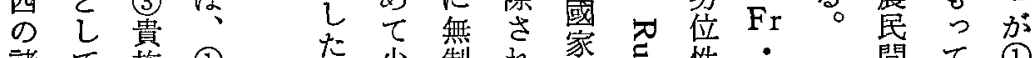

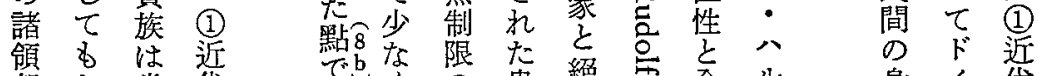

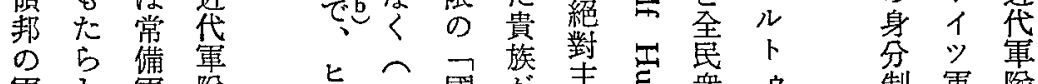

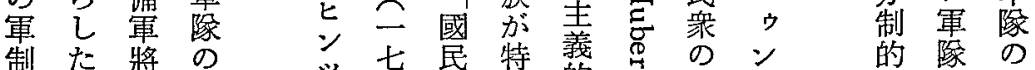

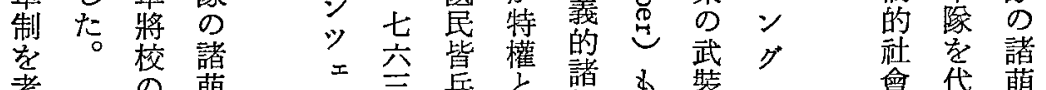

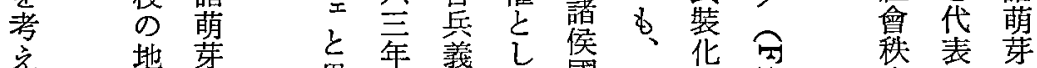

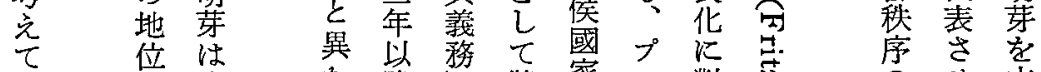

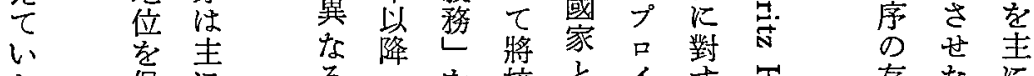

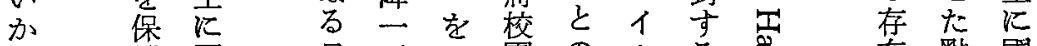

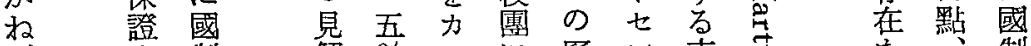
ばさ制 解 \% ソ歷ン支志字、制

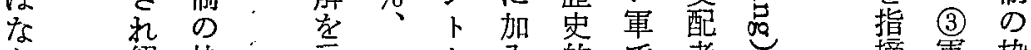

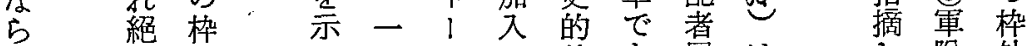

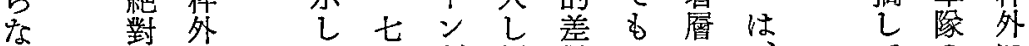

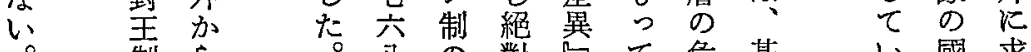

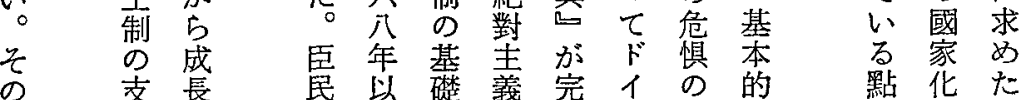

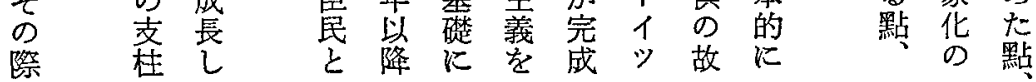




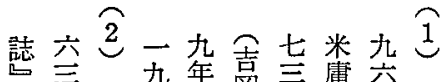
七年中公掆年章合盛

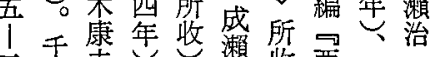

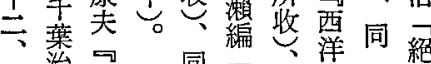

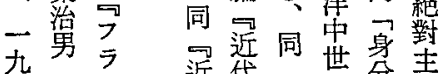

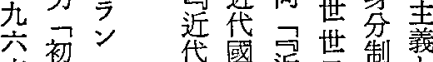
六衫代國近界制焉

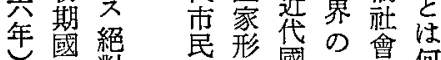
。國對祀成或展會何

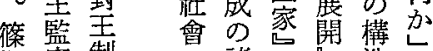

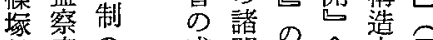
信官の成問形東旁糜

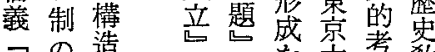

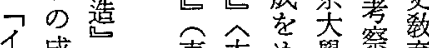
成東菒學祭育 キ立末京鐸ぐ出织

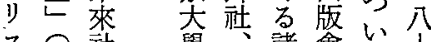

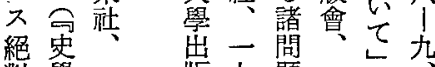
称學一㭊九題一七 琵九會七尤墔一

店問亏同協 3 九四所義 一題亏司會椎究年。㛜。 九所不帒誌点年石上骦 公桨絕法宽淳。部出構 年柴堊形门口雅安造

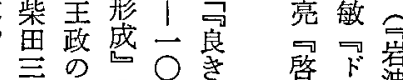
至統出 $\mathrm{O}$ 意啓 雄治泿一堂的兴講

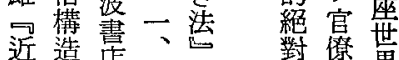
䒫造店九と塑界界 世俞一元帝 義成歔 界揭九上國立定 民目七罭法諭二

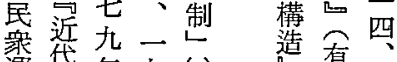
運國年九到罣一

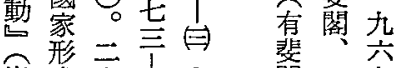

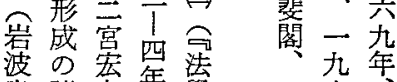

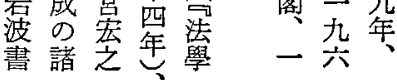

以逆現とブたラとッ導

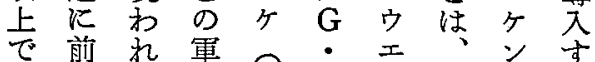

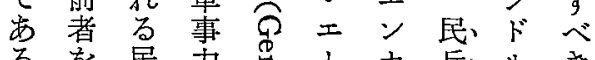

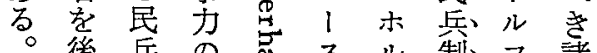
後兵の吕スル制フ諸 者 制 量䓃卜 の度的。方

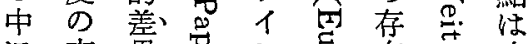

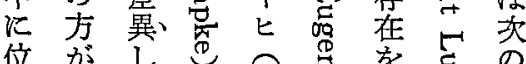
位置方允

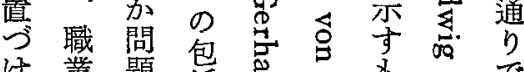

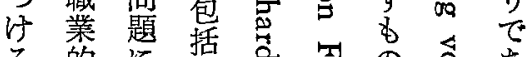

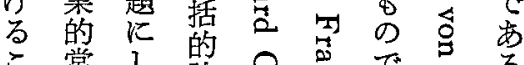

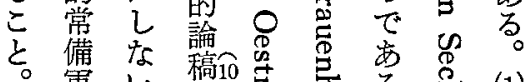

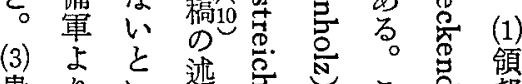

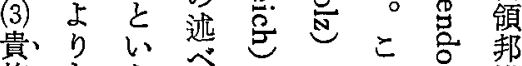

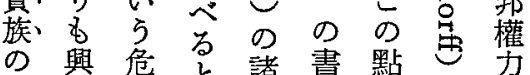

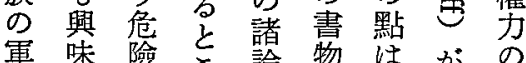
軍味險气論物注がの 隊深性々稿、第軍權

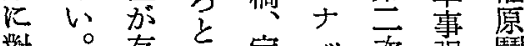

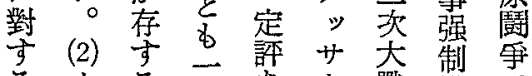

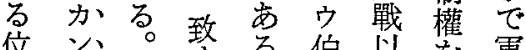

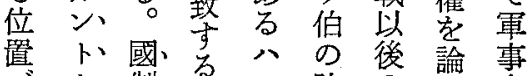

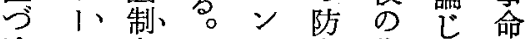

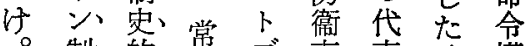

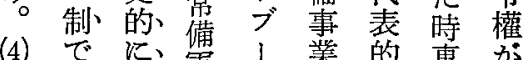

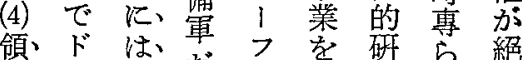

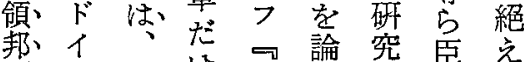

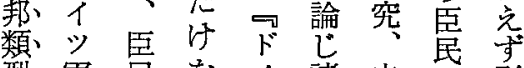
型、軍艮を㦈実合引

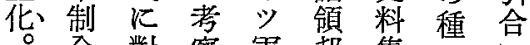

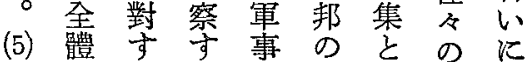
一を去患軍軍出

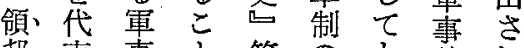

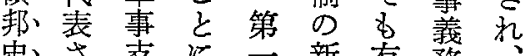

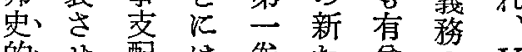

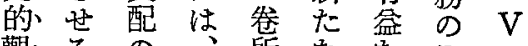

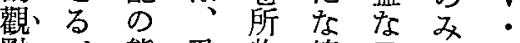
點 “熊 君收螕 E

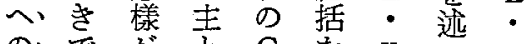

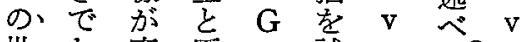
批乱直臣: 陚

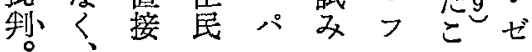


期

江

分 代

加的

就軍

る 制

第 第

期霹霹

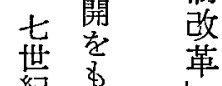

赀

葉虑

皆傅

ポ 葷

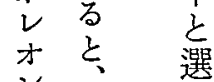

時第 热

贷期 异

第人 葷

期 公

金縟 完

杂志制

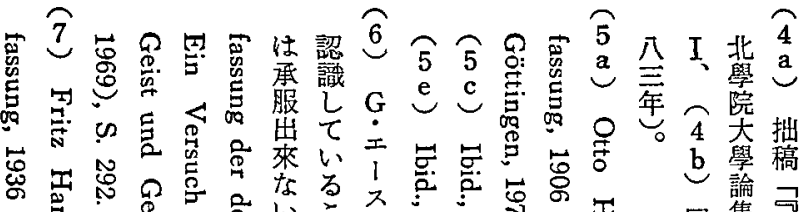
等

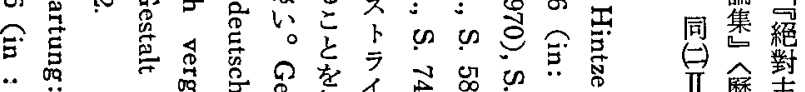

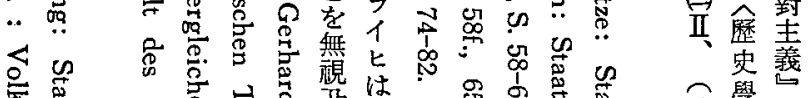

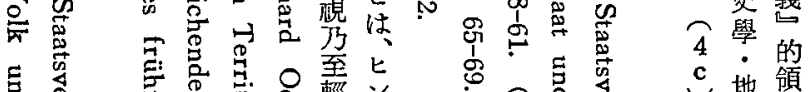

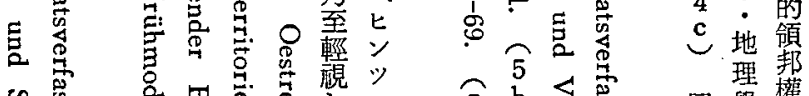

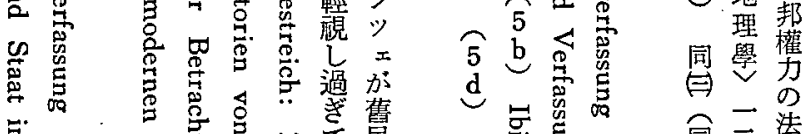

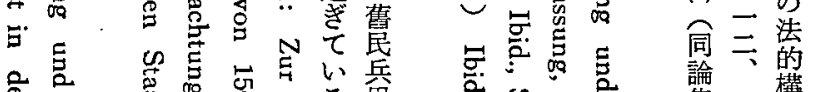

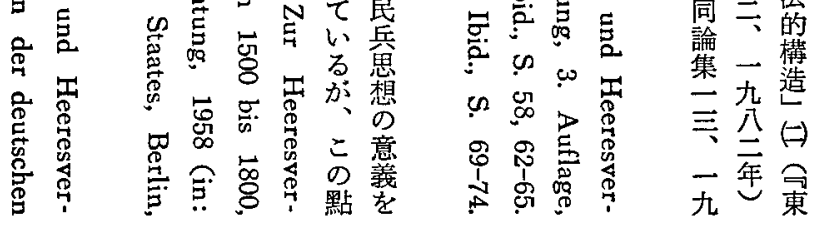

昸

飞莱

䓪軍

さ 制

况

得

उ.?

第 上

期 前

後 期

期

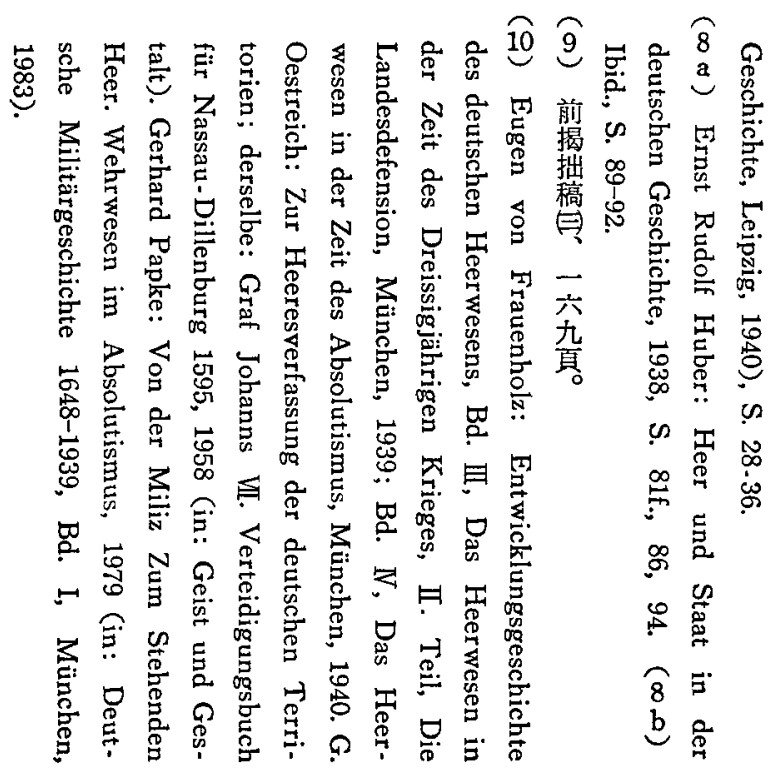




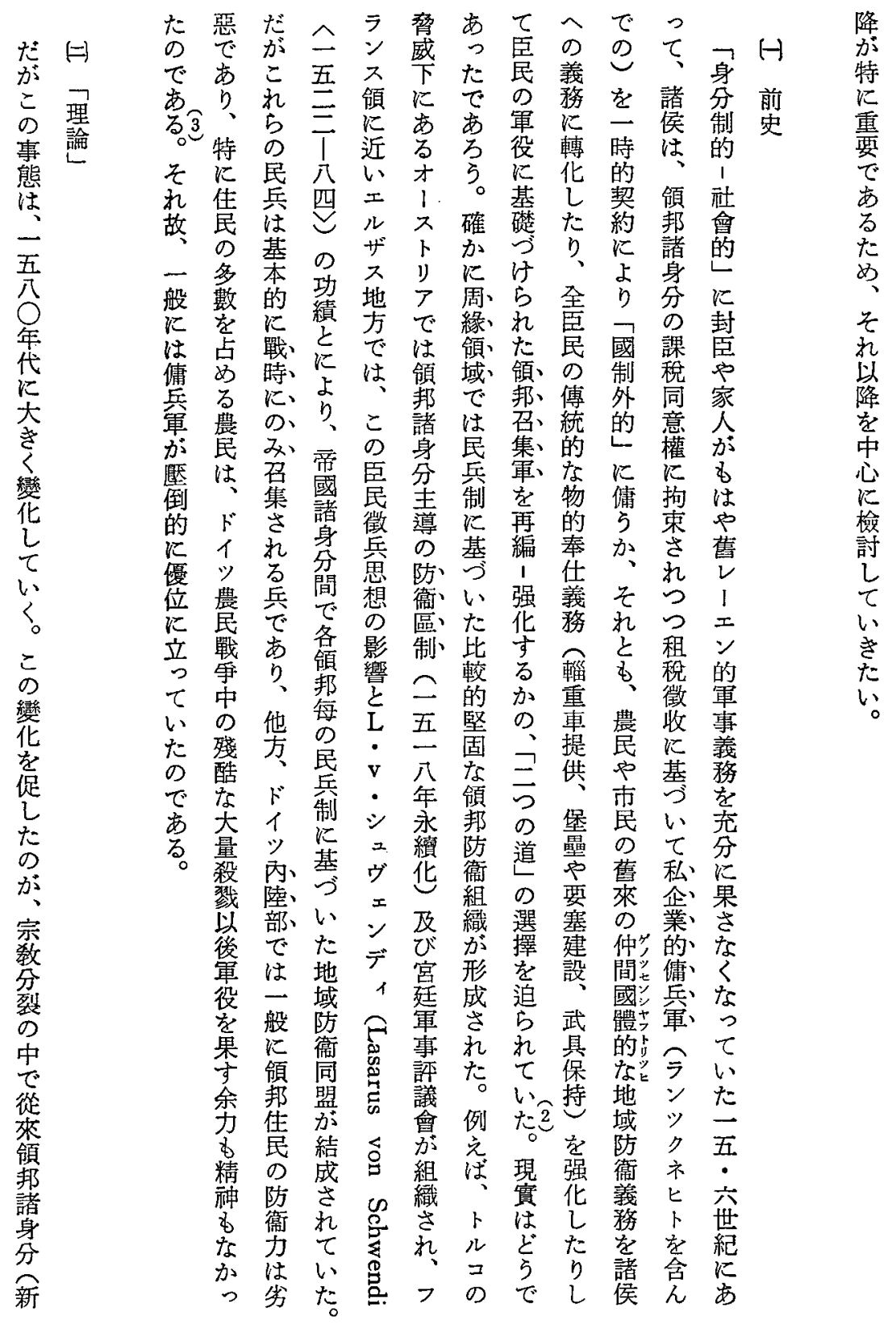




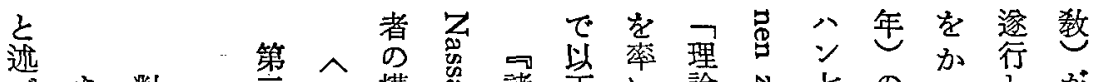
ベあ對 節

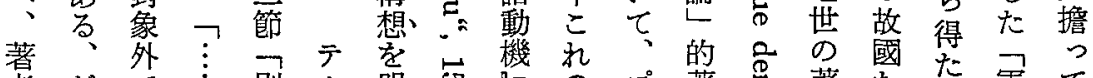

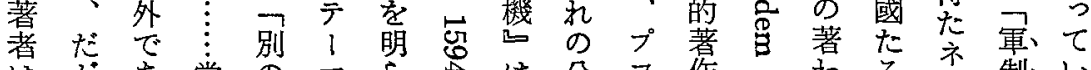

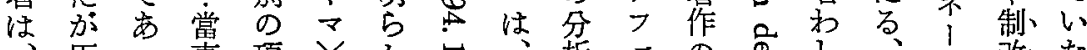

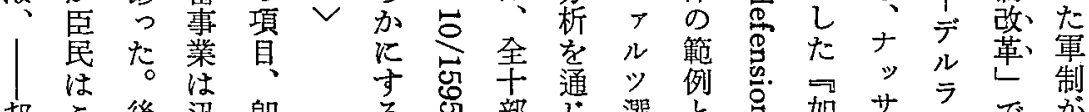

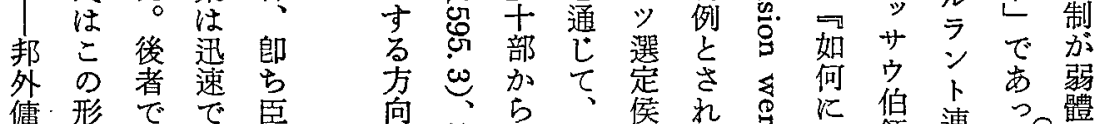

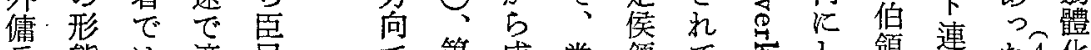

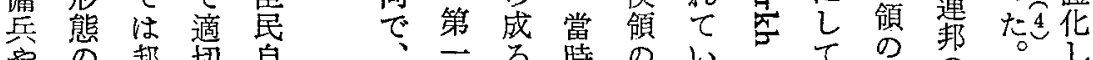

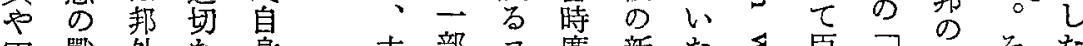

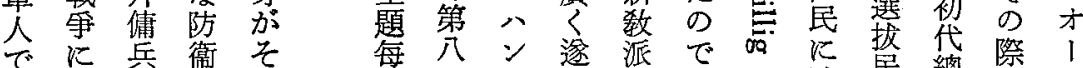

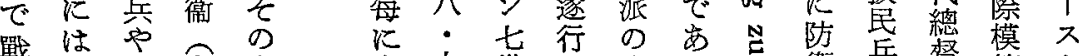

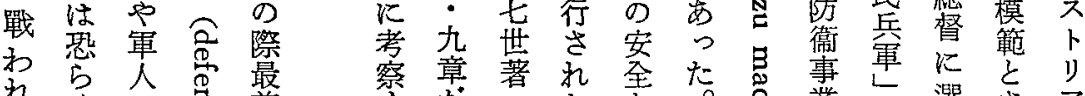

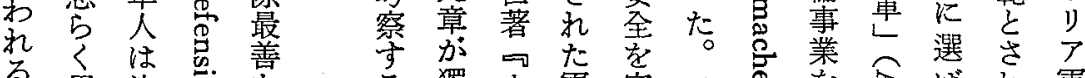

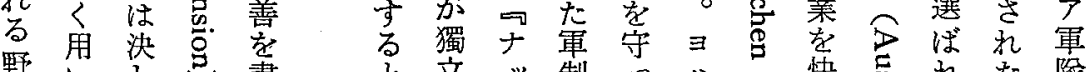

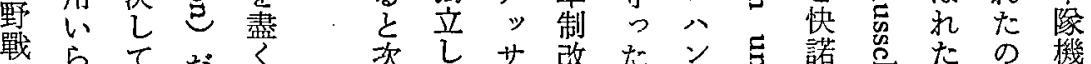

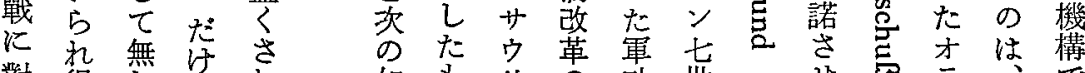

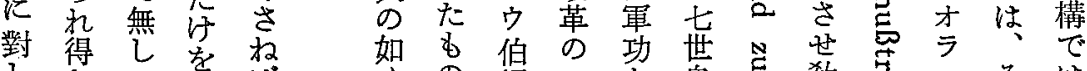
防恋劣学な 㦣方こたか 戰 $5 \hat{7} \zeta$ 学? でじはでた は出采こ 帮、來萊 方, 傭唇野關

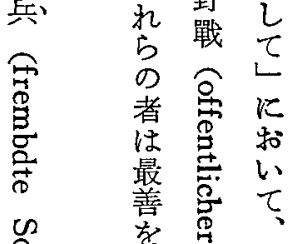

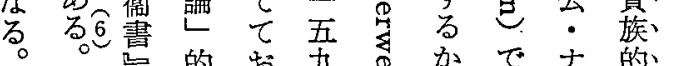

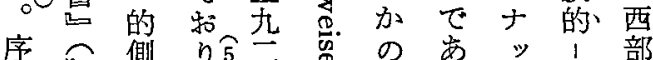

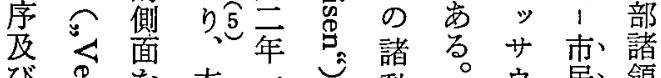
び』を本二動をウ民領 八豆. 解著一《機々伯的邦

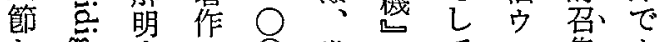

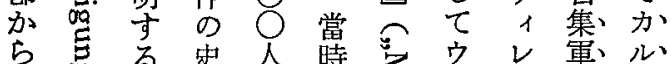
ら吉る串人時芯ウレ曘心

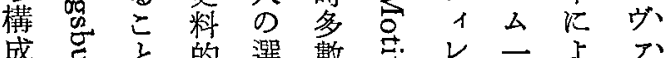

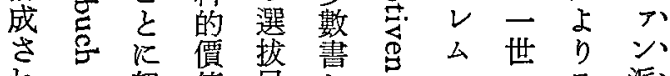
机努值民䂟一派

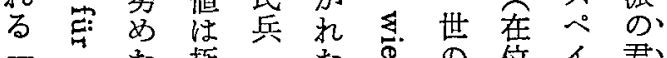
叶た極へたのの位イ君

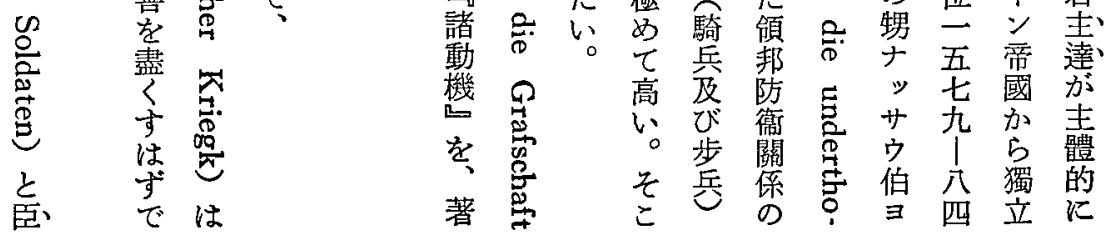


にさ最せ來と化彼忘

最せ有こ学劣点迅

適か る る

た 存統、徵抗 导 他る リ同法

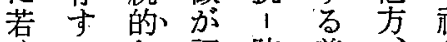

くる認防義

勇 $\mid$ 抵、

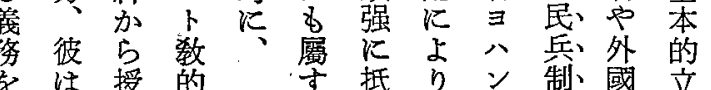

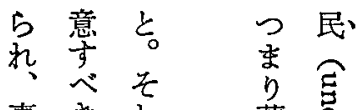

敢 ᄀ 1 丸 . II

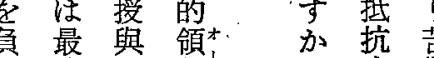

な臣防る 義

者民衞の務之節顺優”

をの 權、で充第て 位

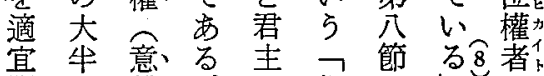

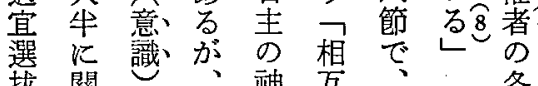

拔關神互、: 各

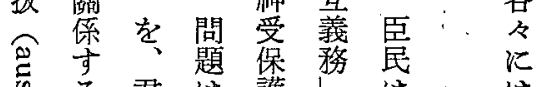

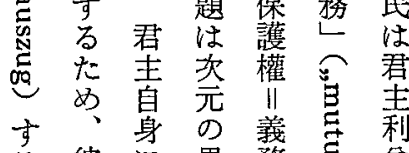

す彼河異務䓌益

占向な之。丶

相自けるすの豆た

違 身さ雨 兩嵒め

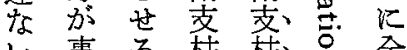

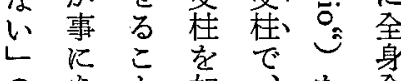

序市京如民省余

$こ 2<k$ 兵張先

う最如合に結ててな

利善 何 基

利竟他せ基码き

用盡君るく吃

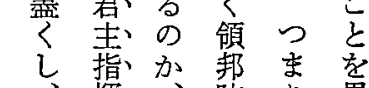

以自權、換衞 、果

午 5 自言 制臣、

は

のの の守度民君

本中防れのの主

惡

論か 衞ば樹 自は

は 5 義、立然こ

、こ務臣に法れ

著のに民努でに

者行轉のめ正對

自㥯化本る當し

5 于吉七 組人场

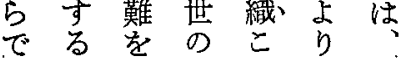

あこ負論糸方既ず

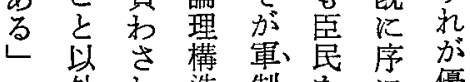

外れ造制をを優

に殺で改防括れ

神害あ革、衞いて

にさるの、のて お

次机核た明り

ぐる 彼心め瞭

手場はでに尔軍

段合市使市事

た、序つ用る訓

学

る

$\frac{\text { 刑 }}{\frac{8}{9}}$

๖

にたす

おのる

いでこ

は

证

it.

5

占

豆

民

不

正

權

椎

क

守

守

己

保

于

る

て

そ臣方酒

の 民組 肪 す

者架織、べ

に强化まま

は奪のささ な

生や理? の

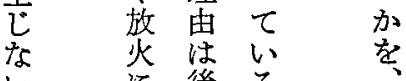

い會艺を後を

何故述 采

故

5

ば

妻る こ。 先 


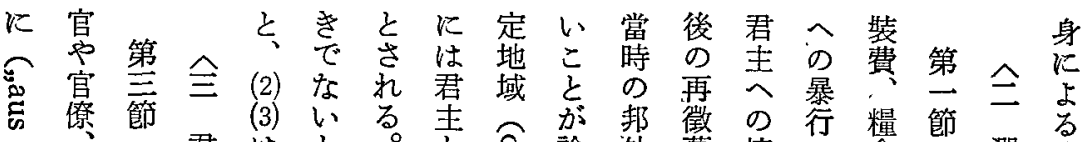

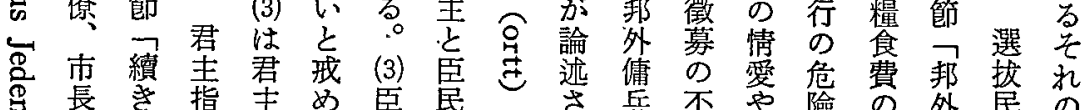

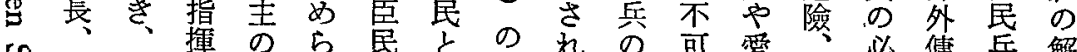
心村 如權 强れ を氐

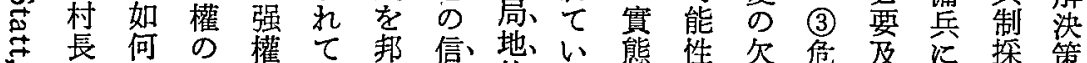
○確的

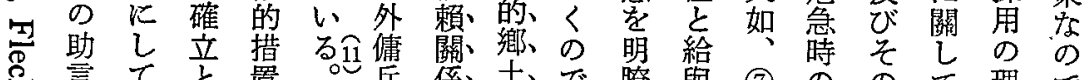

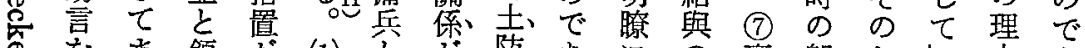

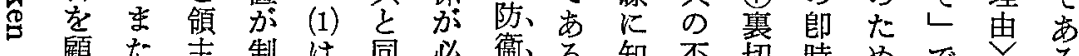

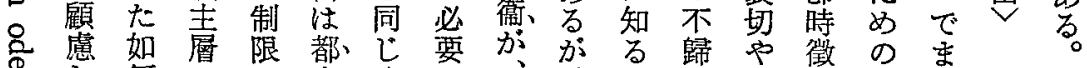

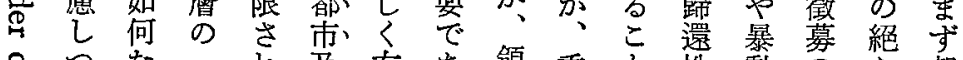

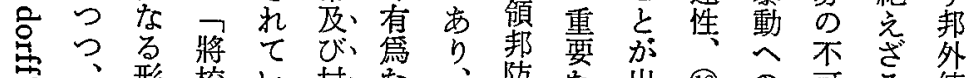

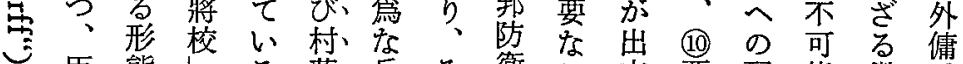

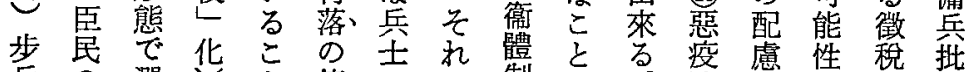

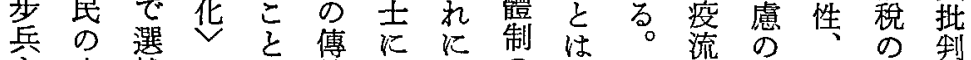

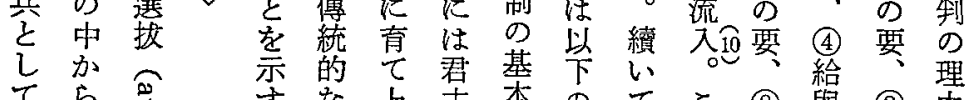

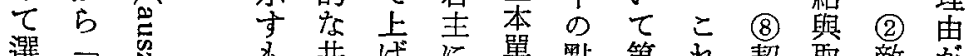

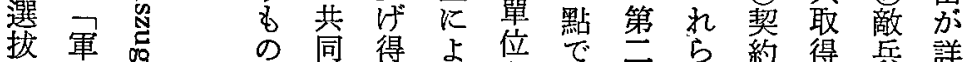
乙 事 包 彼術な が 事 ら で卓れ も越る $\rightarrow$ L $\tau$ た 臣若の 民者 秩 軍学定 編都、に 成市、 寸度、 ^゙び、て

こ市、、

と町、主、

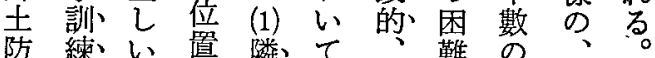

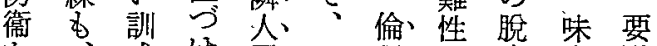
を、或惊同こ理之走方點 單彼、占れ的、臣涉

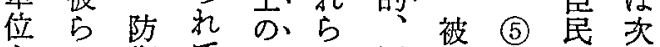
との 衛て 相、の 軍征參に元 乙家の い互、批事服戰對通

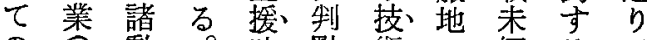
の旁動。助點思の 經るで 再、商 機 (2) 義茂 的敵 驗 盜市

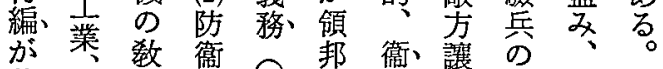
基 農 示 體 意臣 生、泽存掠 (1)

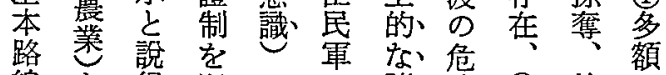
線を得堅にに諸、險 (6) 放の 並村、軍 び 落、事 に 唱、評 三位、議

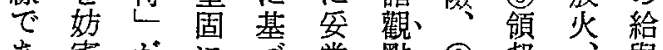

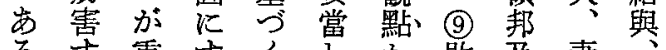
こ导重吉特な吕敗㣻妻武 
こ 閱 軍 體 万 こ 㤩 き 器 の 協

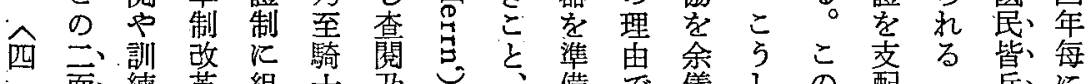

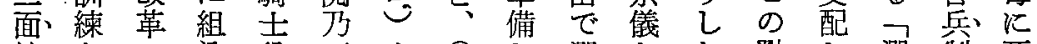
兵性と の 込役至自 (5) 乙 選な た 點し 選制死

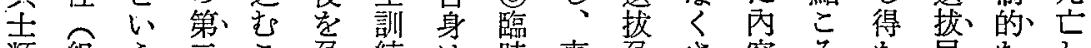

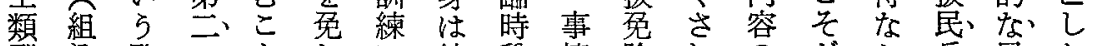

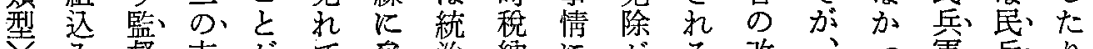

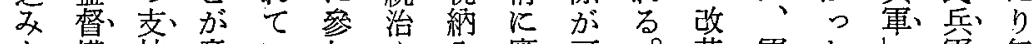
之權、柱意心加や 應可。革軍た車年

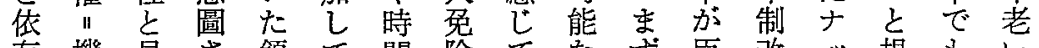

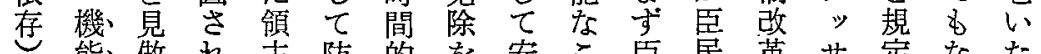
能做热声防的を安こ臣民革サ定なた

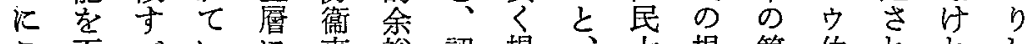
こ不べいに事裕認提、大根第伯れれし

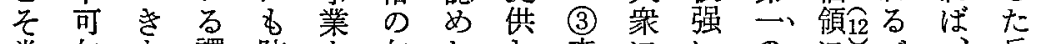

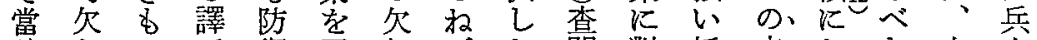

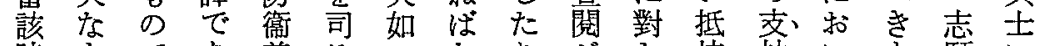

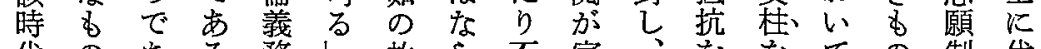

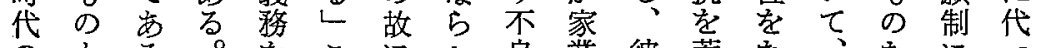

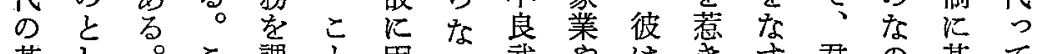
基して

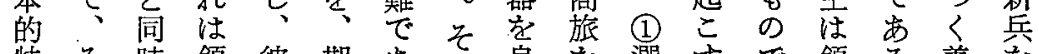
特そ時領彼期あて良を選すず領る。義要 質れ $れ$ 帮 5 待

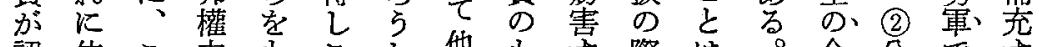

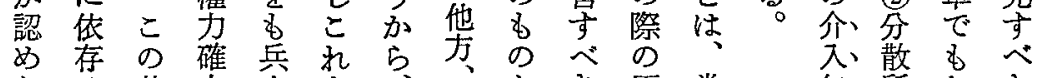

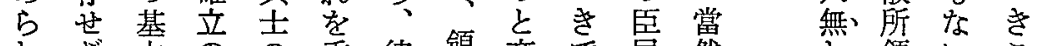
る る 的 極 查、視 5 邦 換 な で得織て 官、る 成身たこ言さ あな 化重 1 の 人分り と只れ るかの 要 訓でにに、、顧る

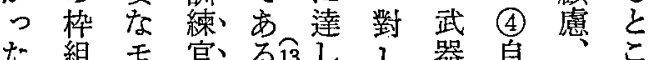

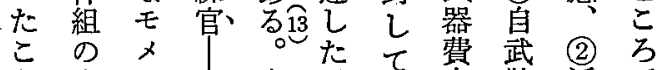
と无ン にで卜將世息は拂唯隣あ

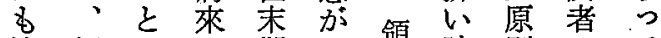
注 領 し $の$ 期 主 時 則 の

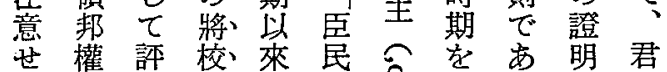

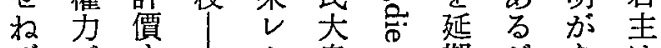

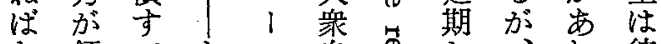

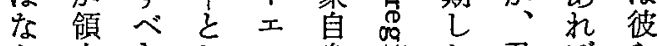
ら圭きしン身高た君ばら

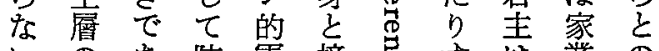

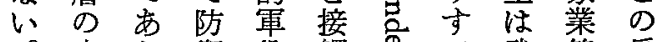
。查り、衛役觸号 ベ武等穻

共 一主々 同、般 の、說 體、的垂、か 單、で事、れ 位、個 權、る に、穴 民莊りそ を、園臣れ 直、領民故 接、素、の 握、單 部こ 寸、獨 肪の る、て 兵 臣 こ村役民 之落に莗 に共就と な同けは 
て官兵化しをの中のに兵年ば臣る後

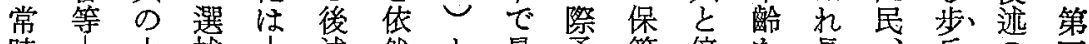
時大拔|述然之最矛管倍を長兵の五

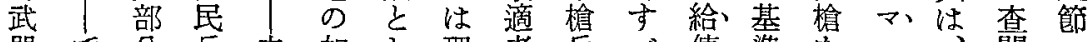
器で分兵未如し理者兵 ベ傭準をス、、閱 ᄀ を市をのだくて念方のき兵飞武ケ特及續

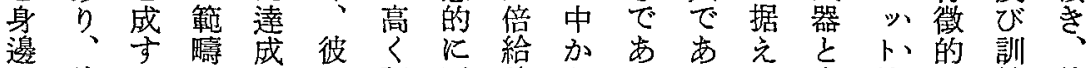

に彼のにさら評區傭らるるるるす寸銃に練彼

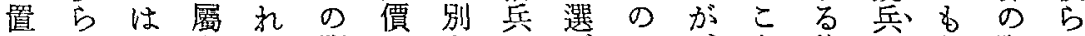
い注さ君さ訓しさにばに、を倍年際は

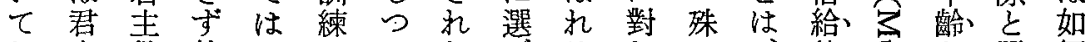

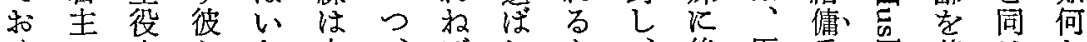

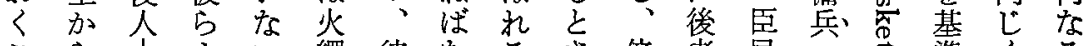

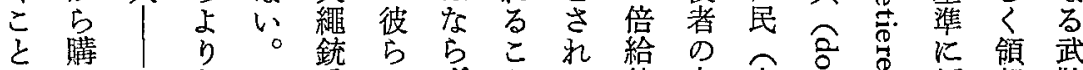

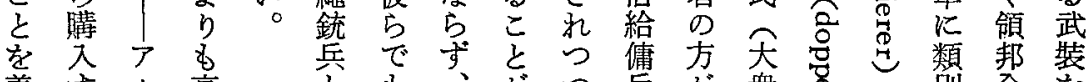

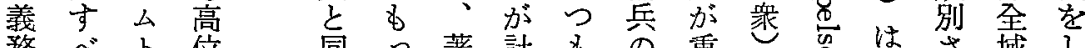

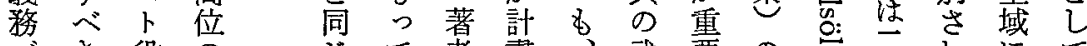

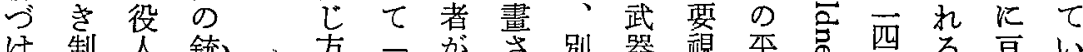

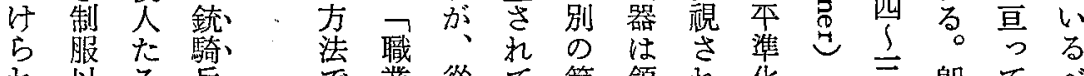

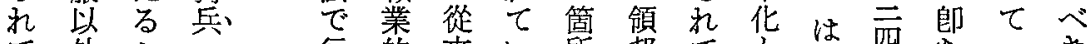

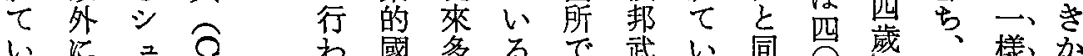

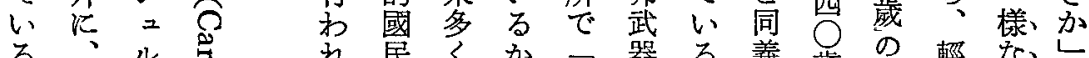

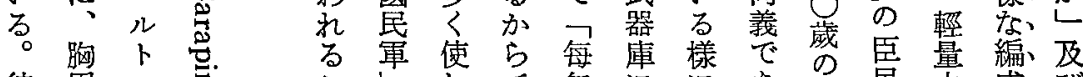

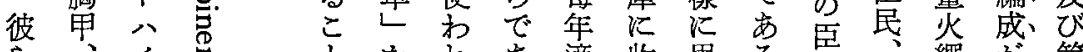

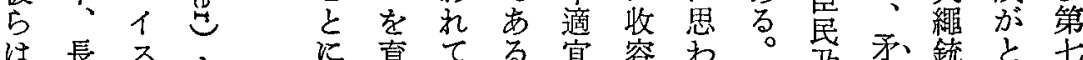

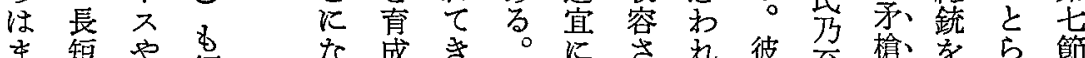
ま短や領な成き机さ彼至柃を節

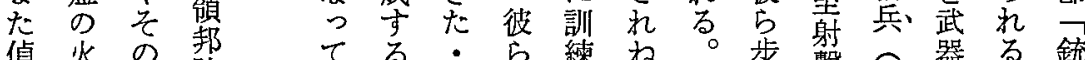

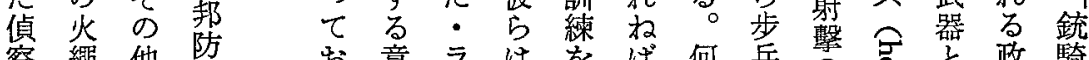

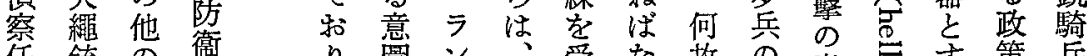

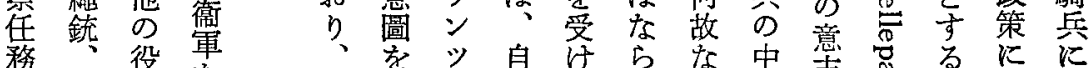

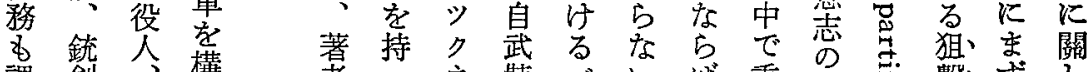

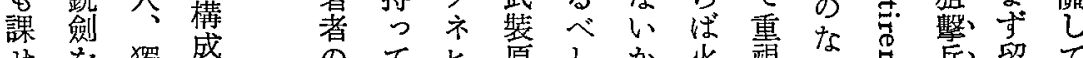

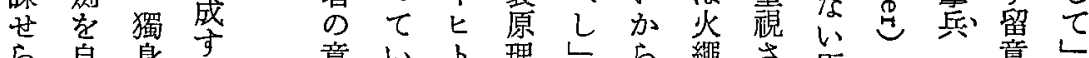
ら自身す意

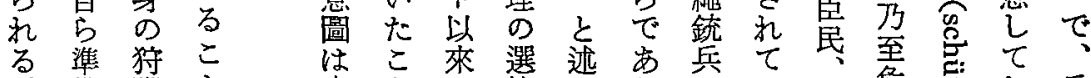

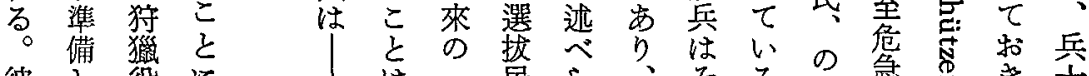

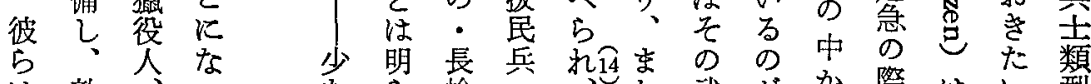

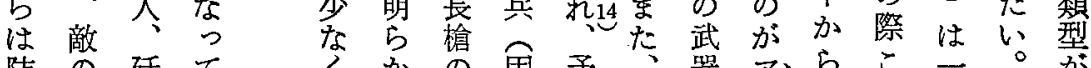

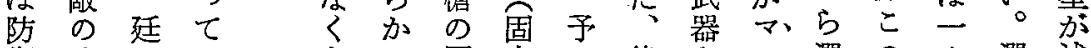
衞攻丁いで軍有め後をス選の六選遮 戰郻、る る

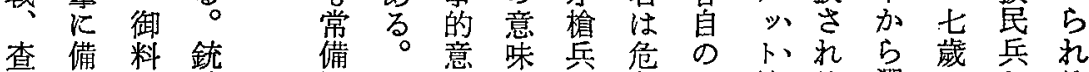
望真林騎軍但義宁急家銃る。選のたる。 
になに長が連得されたさ領の゙第へをる的指訓

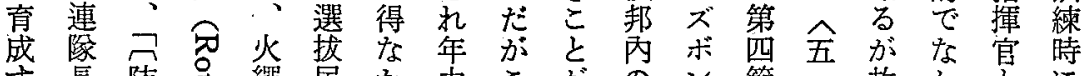

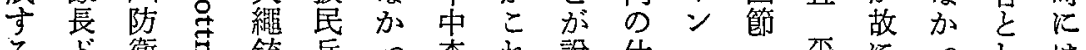

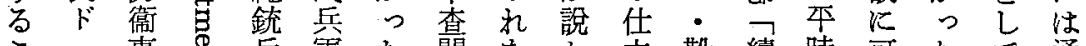
こ・事怘兵軍た閱をか立鞉續時可たて通

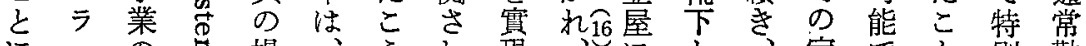

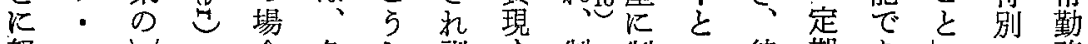
努 又 $凵$ 合各し訓卞制制 め大責は年練る服服っら的っだ騎を た17 部責分特訓を上にのたはなたが兵急

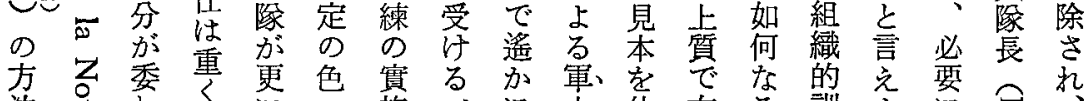

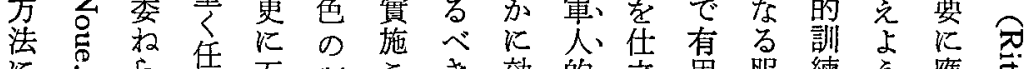

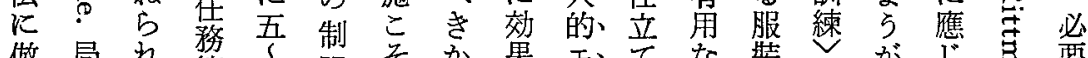

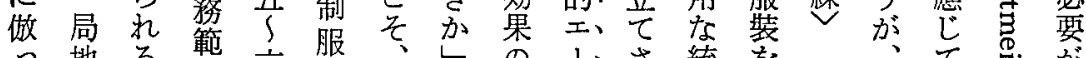

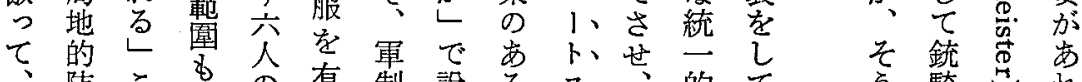

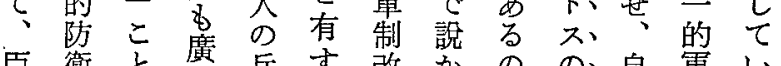
臣衞々黄兵寸改かのの、自軍い 民軍飞主る革机架涵占服る

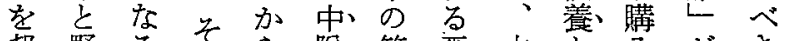
邦野る等 外戰。气゙成合時著軍、兵占

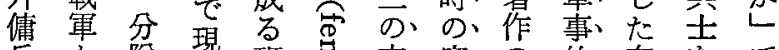
兵方萇貫班㞯索定の的布をで

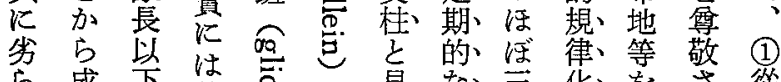
ら成市彼总子見な言花壳さ從 なる指彼主做組分の支机來 い徵揮の配に守織の重拂る。 兵集官配區のべ的一要いべ雜 葷の下分下き訓を性期き多 にを目た分部毛練、占㤎限勇な 育訓的るさ單の訪述の氣農

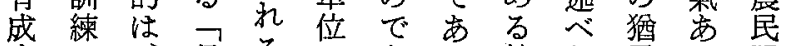

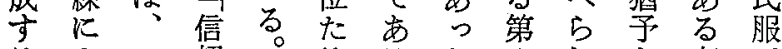
るよフ賴基るる。六势を存で こり う基分、。節る認在は

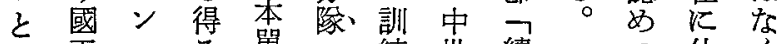
に王ス当單練世續引仕く

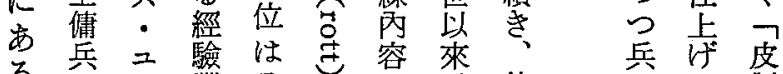

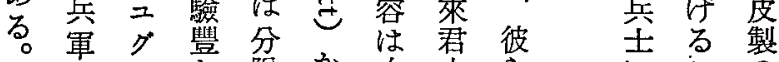

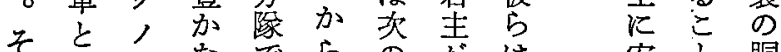

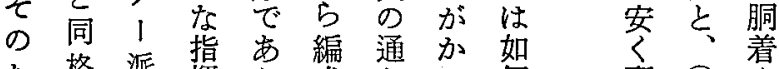
た格派揮り成り賣 (2) 着 めのの官、さでてに却君羊 軍高達分机あ實指主毛 臣降名榢る各行揮べは製

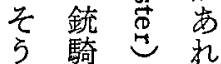
し 兵 等 た 肪唯 合頻㶵年 役拿命 人去四 達て用るな 步Wそ夕

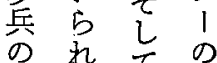
指る 興 燕 揮气味 类 官字深軍 なあこ二 るりと臺 こ得江分 子纱 はと积 充構萊支

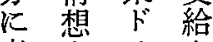
考さイさ 光れツ水 占 得方㚡兵彼 得等兵彼 う。防で自 衛慣身 
水超保いる

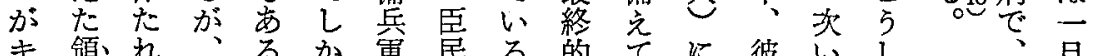
†領れ、る加軍民る的てに彼い儿旦 リ邦るそとるをののにの總らでた選 ス的しの述 ベ忠で|防射は班組拔 卜利气際べき含實あ、衞熬野每織程さ

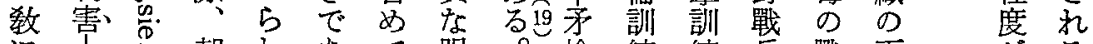

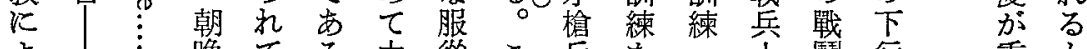
よ

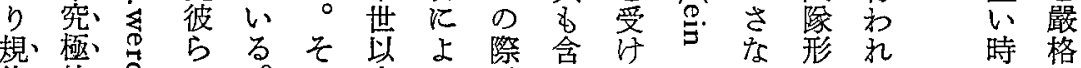

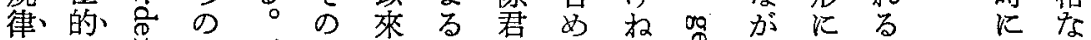
とに、た更たの伯主てば㝵らな訓は罰

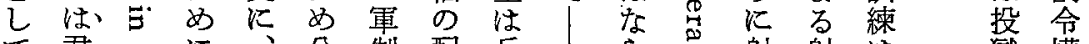

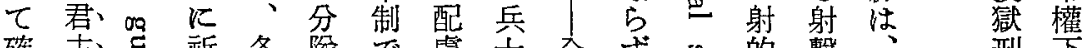

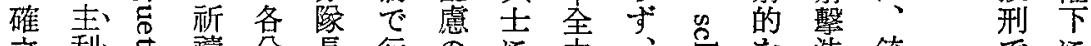

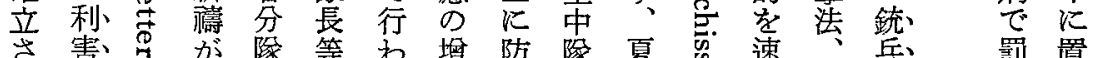

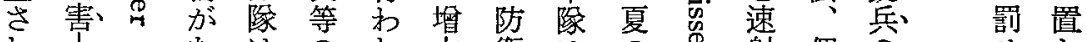

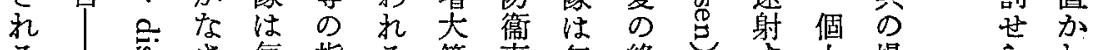

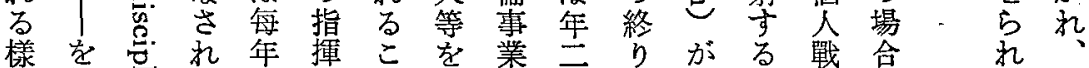

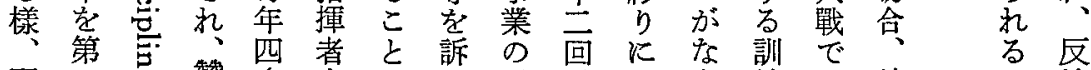
配 慮義邑美八身な西要上各れを走の でや

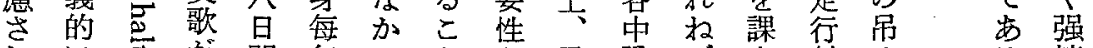

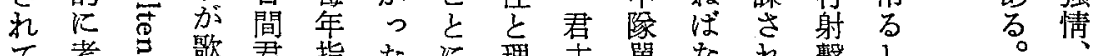
て考

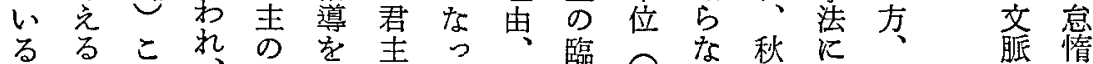

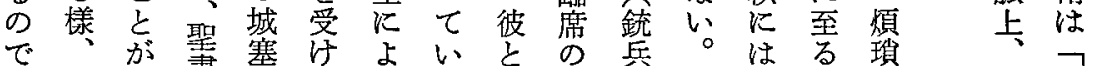

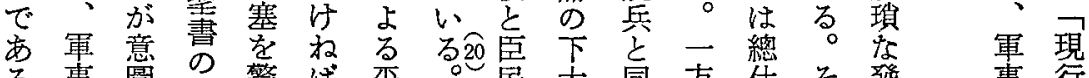

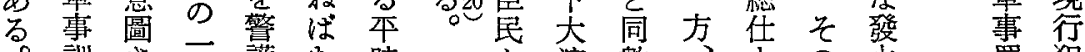

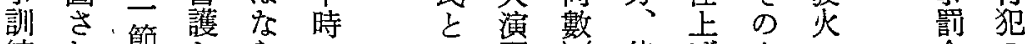

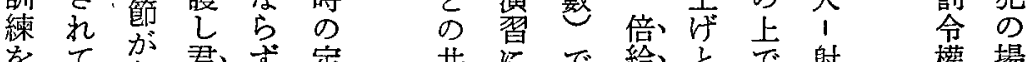

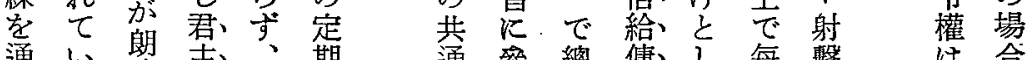

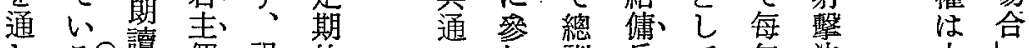

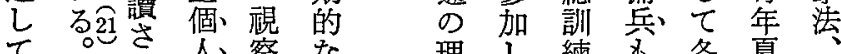

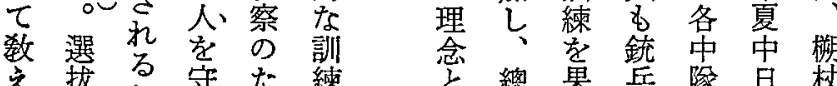
范垫こ守た練点總果兵豚日林

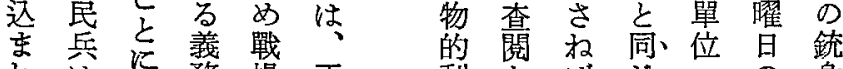
れはに務場正利をばじっの身

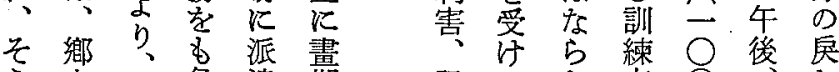

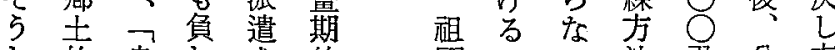

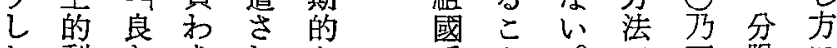
た利きさ扎愛と艺至陵に エ、害規れる評少にそ奇至長始 小を律てこ價理なし襲 


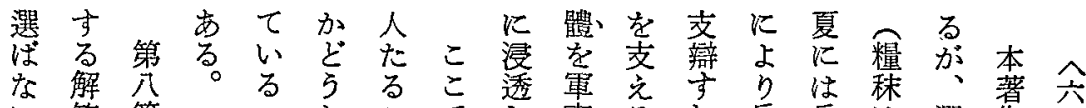

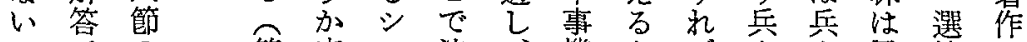

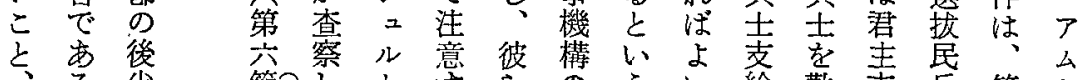
(3) 㢳著農 に唯管 罰 農 武 金民 器 や 戰 を 租 淨 與 税 勃 点

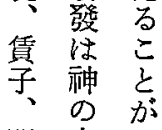

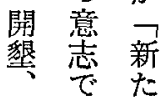

改めな

焂 、農

賦、尼

役 三戰

等 葆 争

を件して獄で單

负客

せ (1) 發

極 選さ

度拔

飞尾る

傷 兵

めので

分

け住な

る

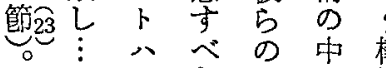

正六我想浩彼

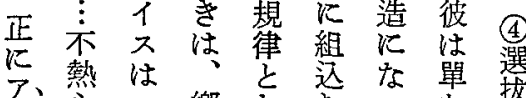

歡 支 兵第 卜

分熱

、待 給 公 公 制

制断週㤎て

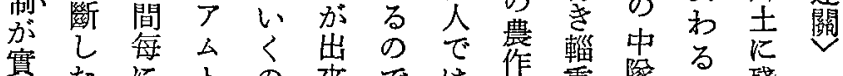

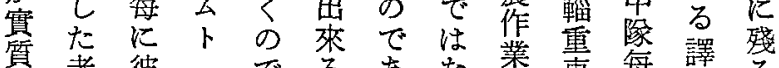

䉓者彼へでるあ代車每譯る

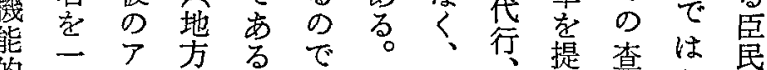

的畫么行。市君鄉の供䫝な氐

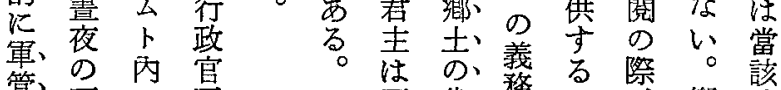

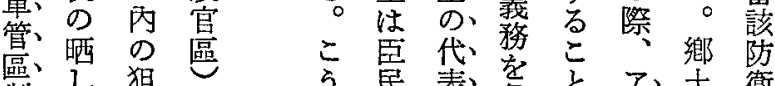

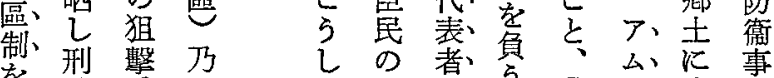

を型罊 吕

た $\div$ こ (3) 卜殘業

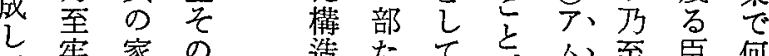

乙窂家の 造たて方山至臣何

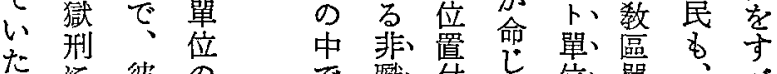

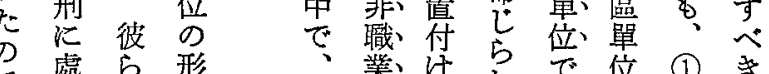

で處 5 形、業洁らで位 (1)

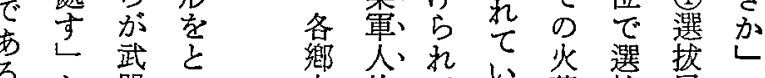

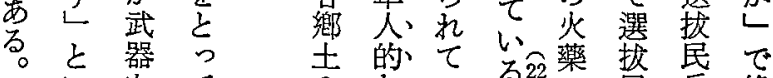

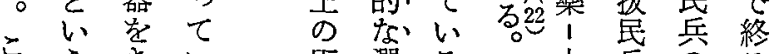

の 5 ま

こ指と制必入あ, 上通に選至軍牛

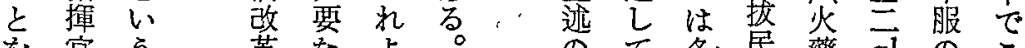

を官 5 革なよ。の て 各底藥 $\mathrm{gl} の こ$

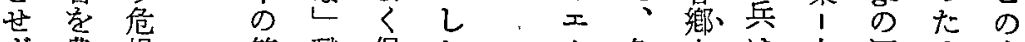

ず、農惧第、職保加...1 各土、火酒め表

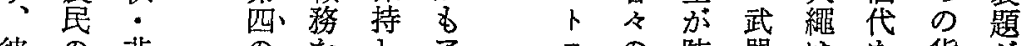

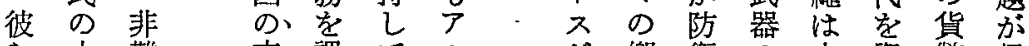

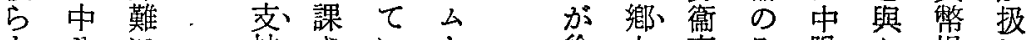

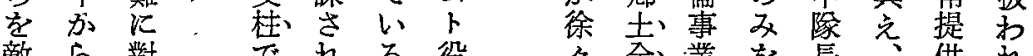

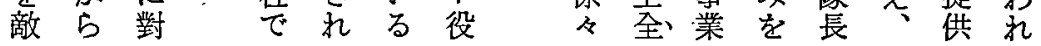


剖来六ま

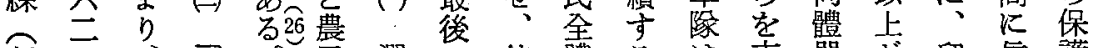

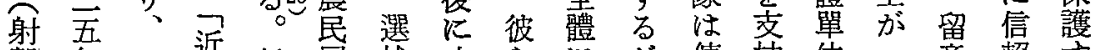

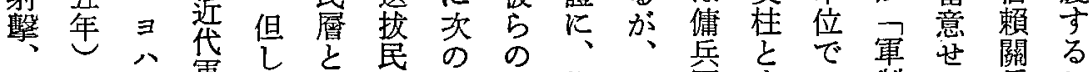

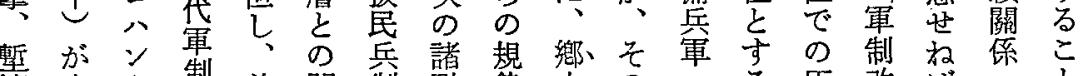
撉中制前間制點律士、のつる臣改ば

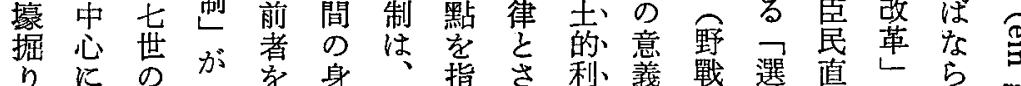

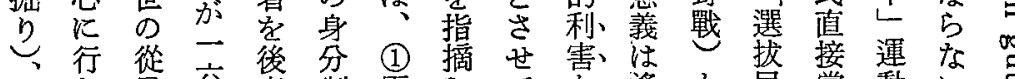

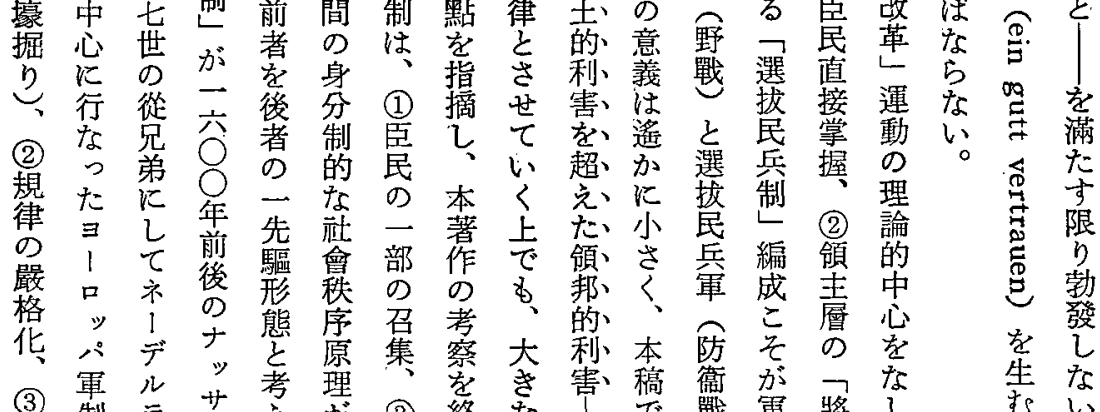

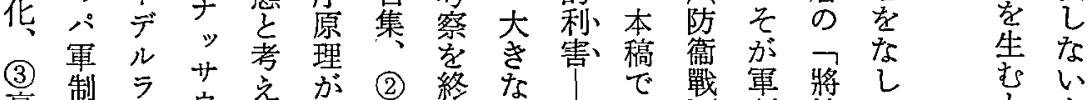

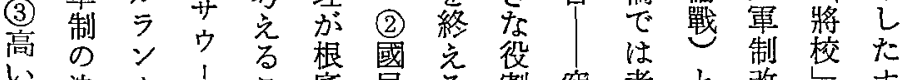

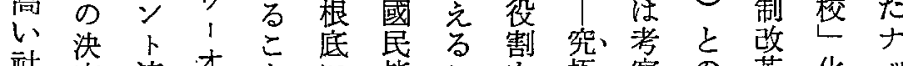

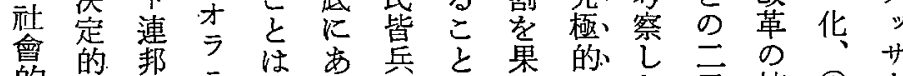

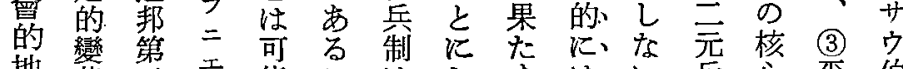

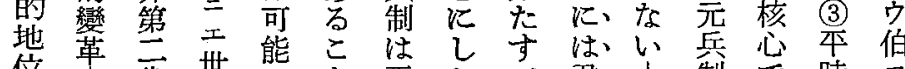

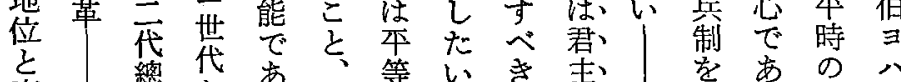

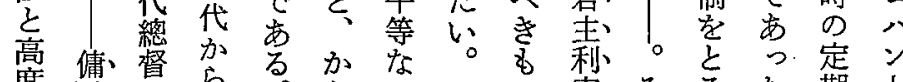
度 傭、督 5 る

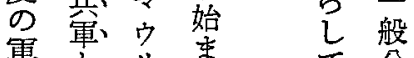

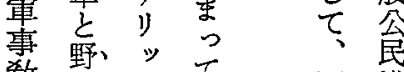

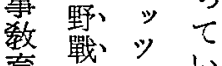

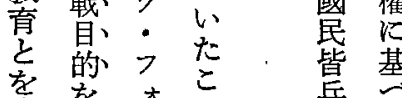

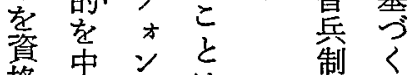

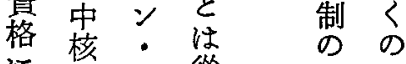
飞览才從 可据亏來種對 当管 母 $\tau$

或的認

出 (1) 在讙 身平位さ

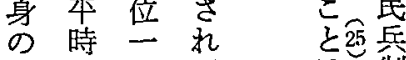
將向五在制 校恒入

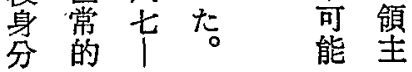

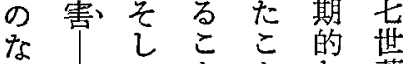

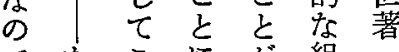

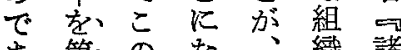

あ第のな、織諸

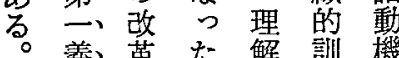

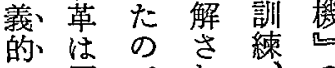

水軍でれ

考事要た (4) 青

家機多で市

方構|西公容

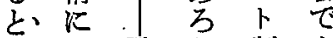

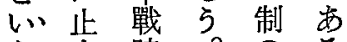

万人時。合

土占召こ軍

虽管

不各尼尘制袁

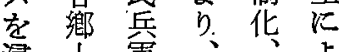

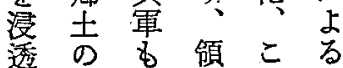

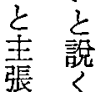

す

る先

它

要君

る24主

當 岳

該 䜿

防潏京

事

業 相

が奛

體 義

制 務

維 ᄂ

持 飞

を 基

目<

的 領

と 邦

ᄂ 防

乙 衞

いが

る 兩

こ者 


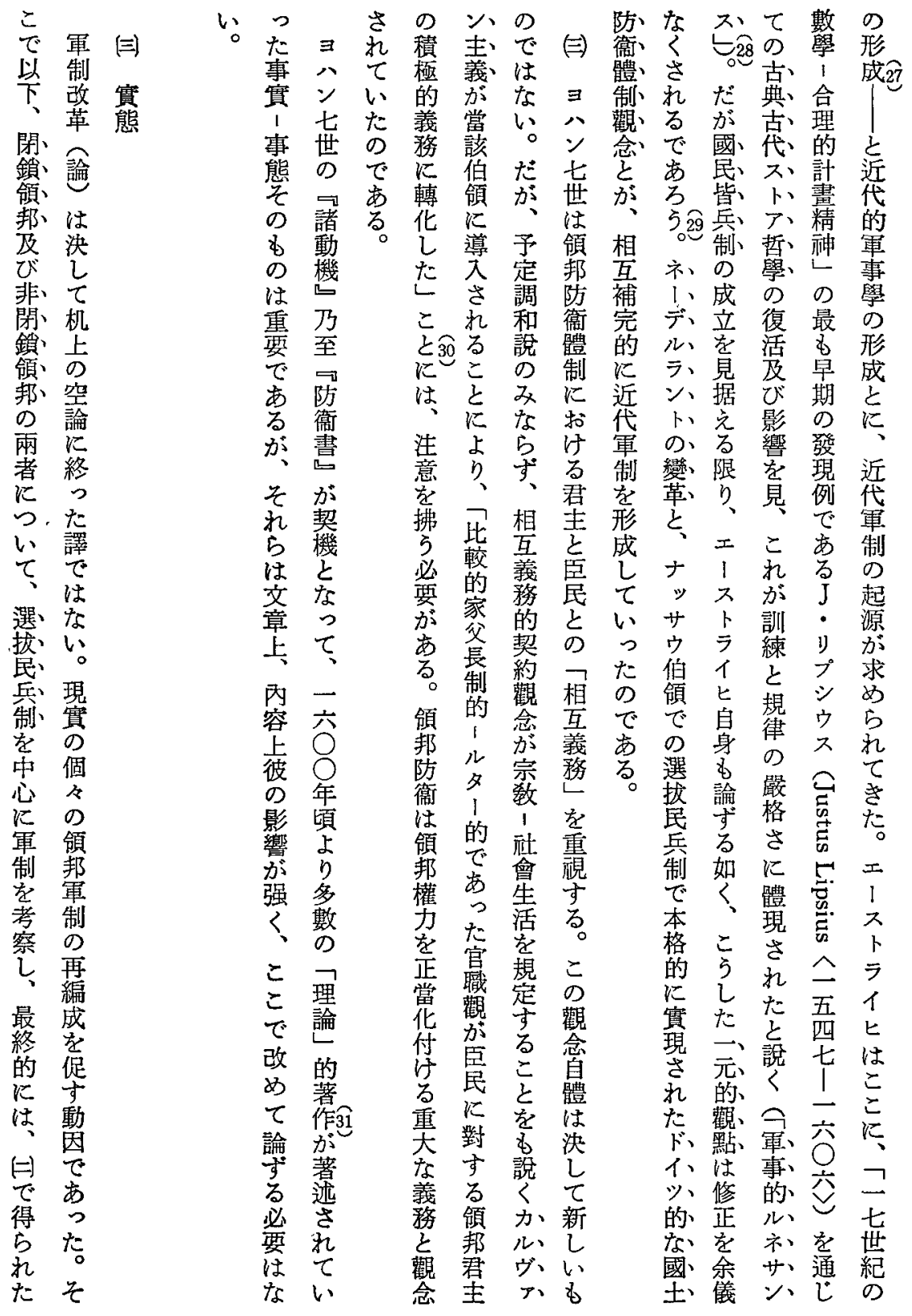




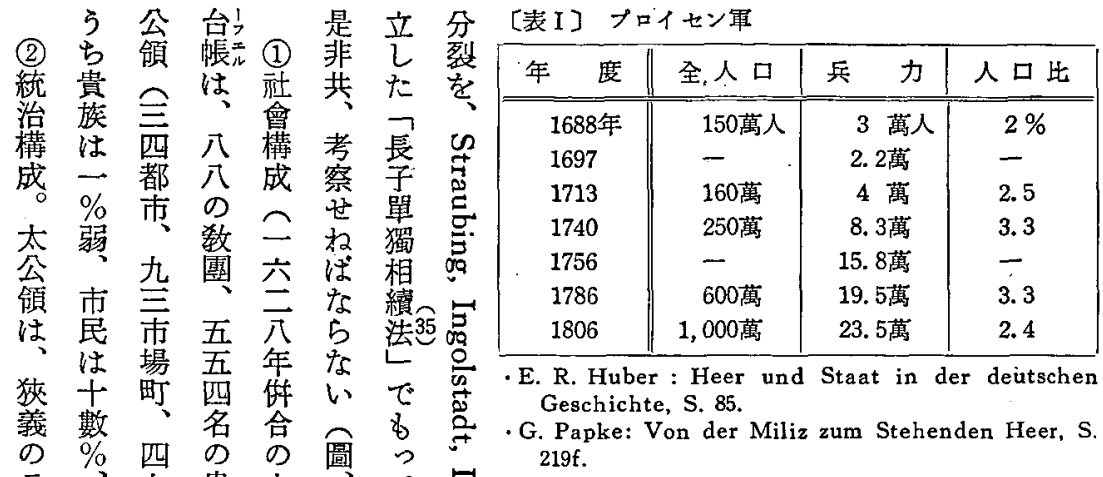

ラ、七貴上寺七

ン 農 $\bigcirc$ 族 プ 參 切怘

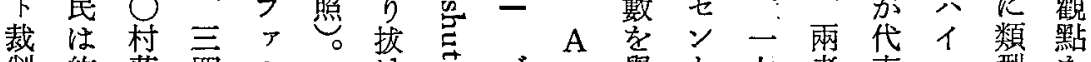

制約落四 ル け

所八笛家

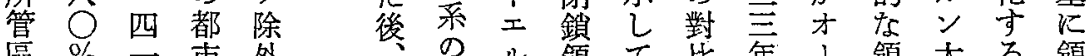

區 \% 二市然

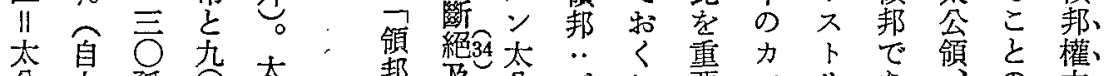

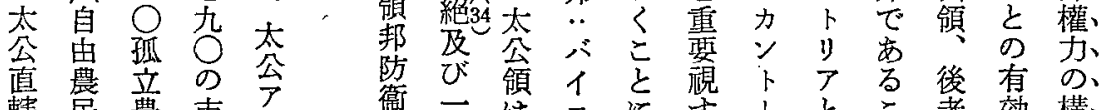

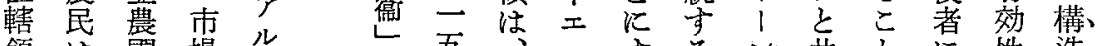

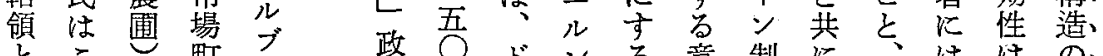

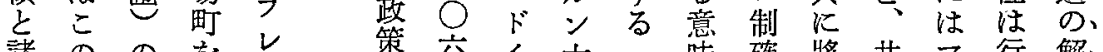

諸のの策六く

身中面領七齐 年

分の積 邦 $卜$ 最 次で領 I33 後身比ン中に

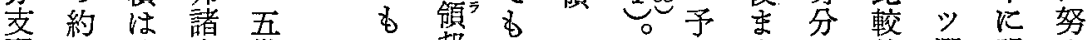

配四約身世界帮稀方に的選明め

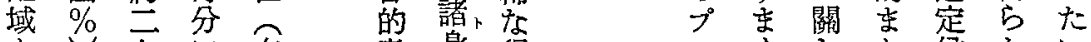

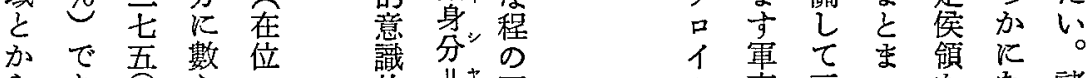

らあ

構 つ $\mathrm{km}^{2}$ 上五 議家國類た 取る 領

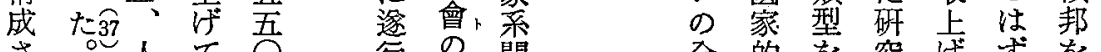

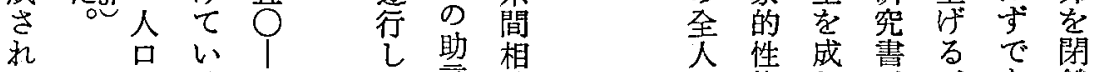

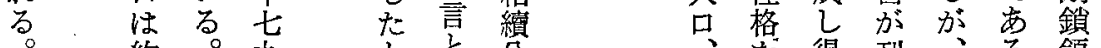

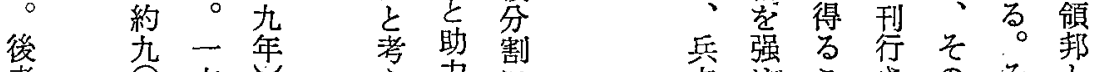

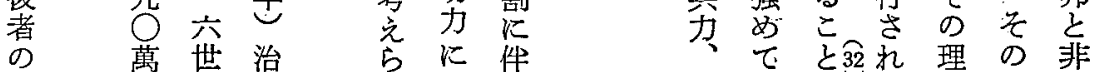

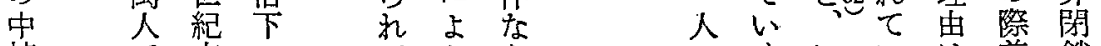

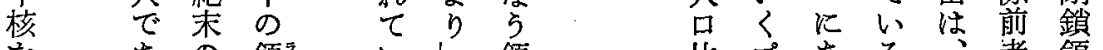

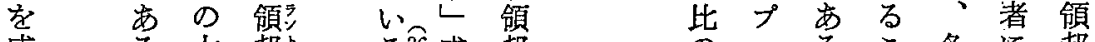

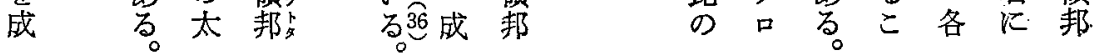


ドイツ絕對主義的領邦における軍制

[圖]18世紀末のドイッ

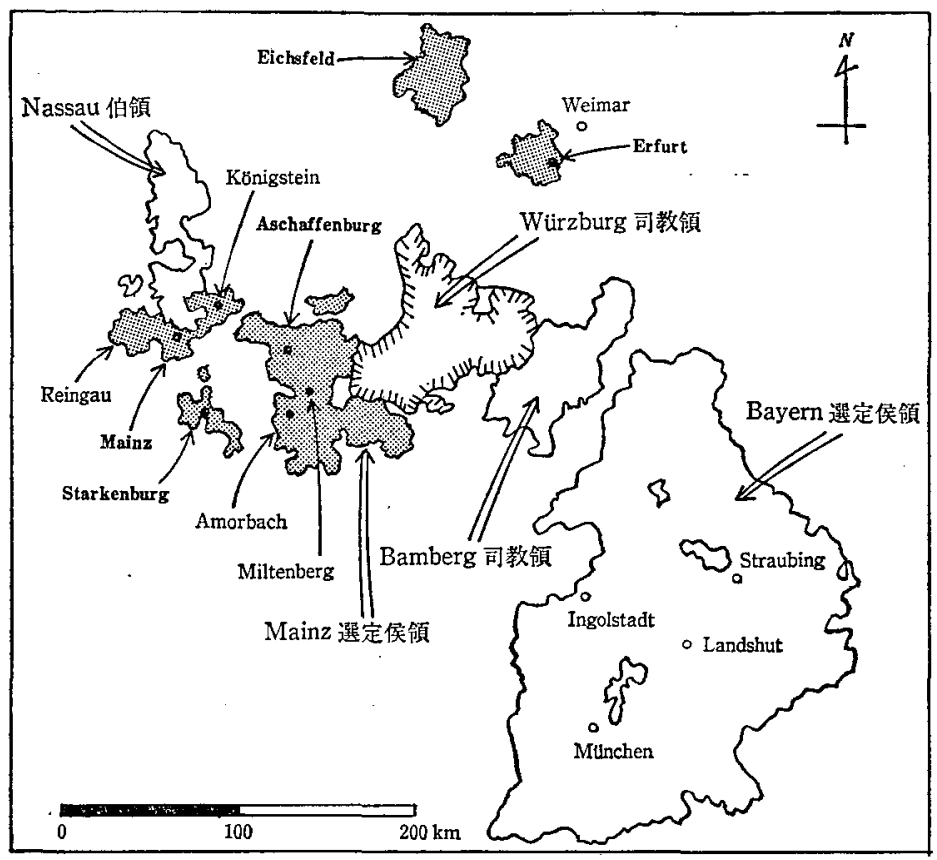

-Völker, Staaten und Kulturen, Georg Westermann, Braunschweig, 1971, S. 68, Walter Fabricius: Verfassung, Verwaltung und Gerichtsbarkeit in den Kurmainzer Ämtern an der BergstraBe bis zum 19. Jahrhundert, Wiesbaden, 1971, 付圆上り作成。

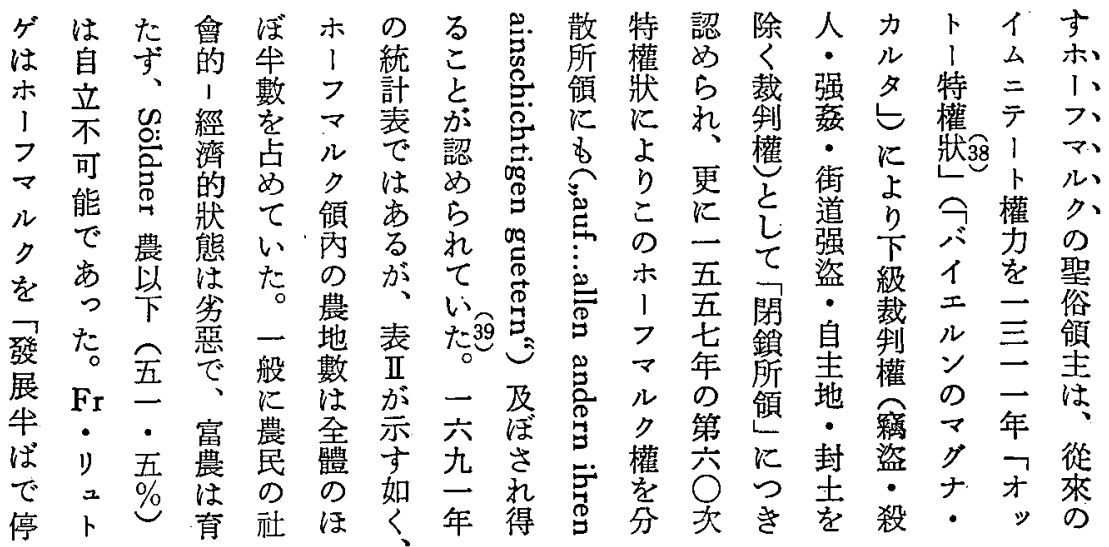




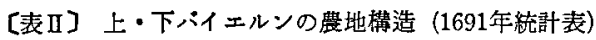

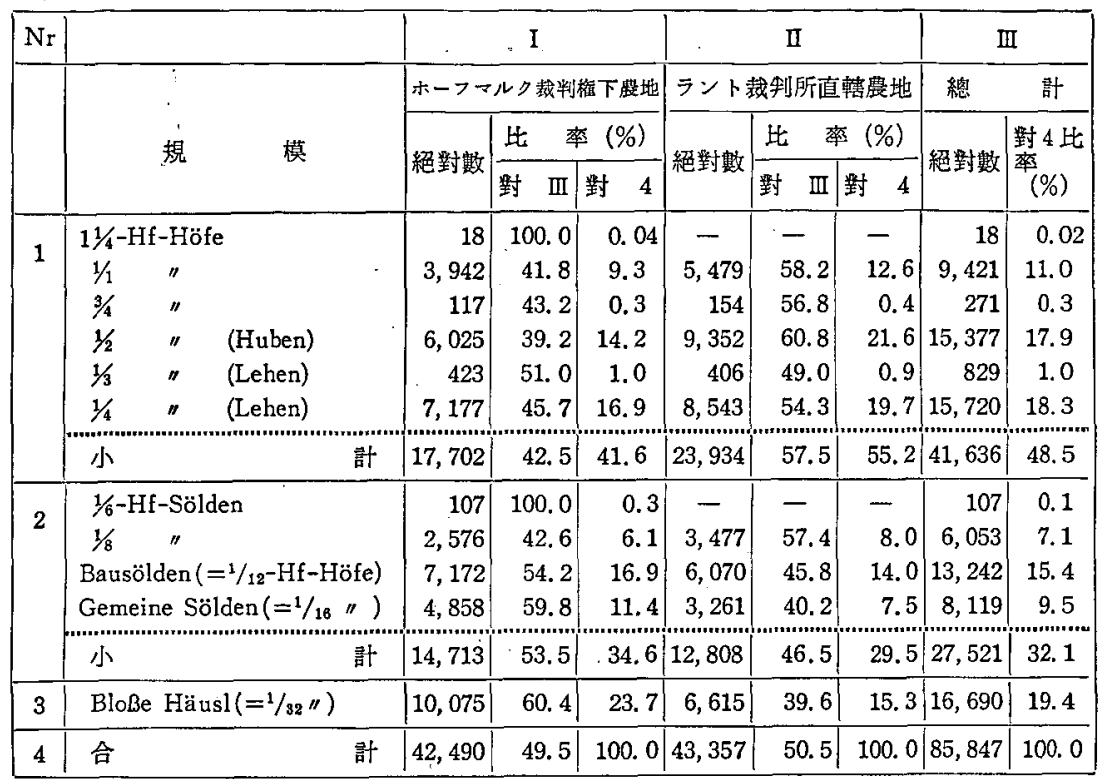

1-Hf $(=$ Hoffuß $)-$ Hof $=2$ Hufen

- Eckart Schremmer: Agrarverfassung und Wirtschaftsstruktur. Die sudostdeutsche Hofmark-eine Wirtschaftsherrschaft? (in: Zeitschrift für Agrargeschichte und Agrarsozio-

logie, Bd. 20, 1972), S. 49, Tab. 4 より作成。

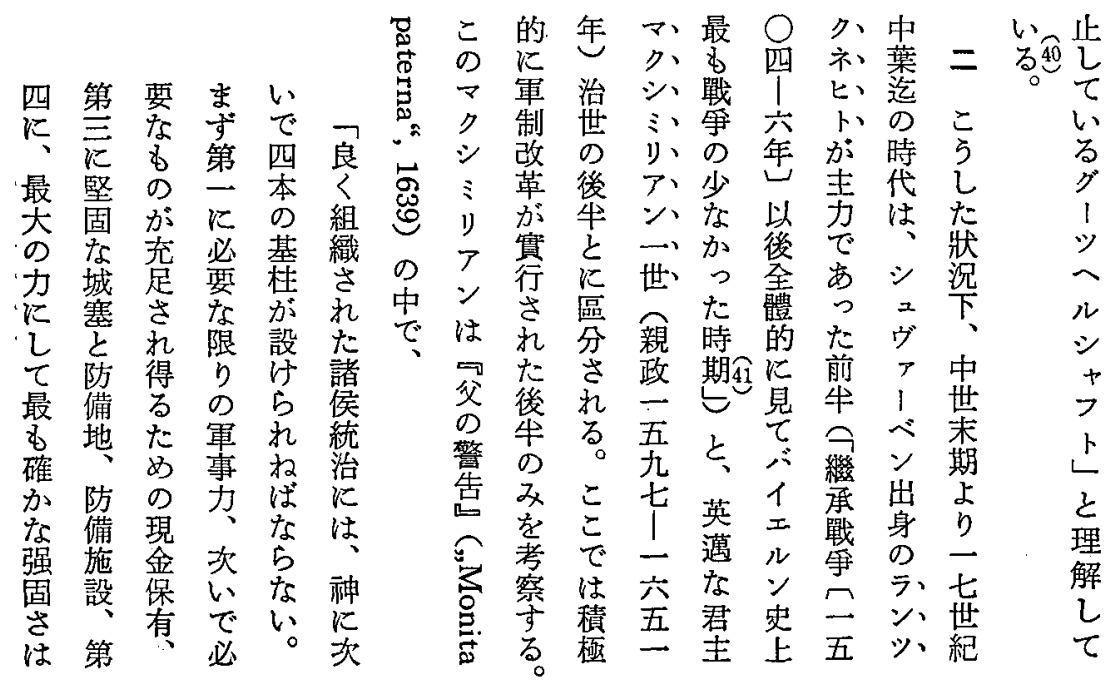




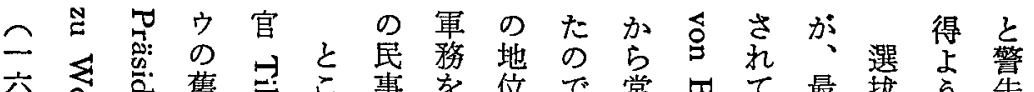

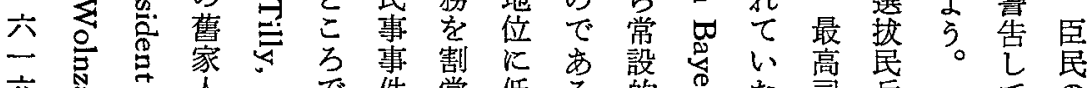

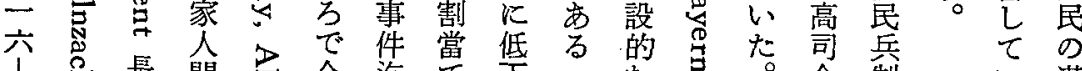

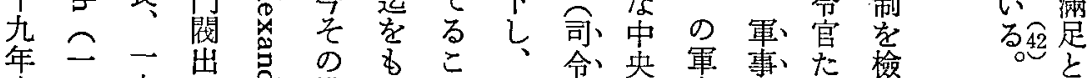

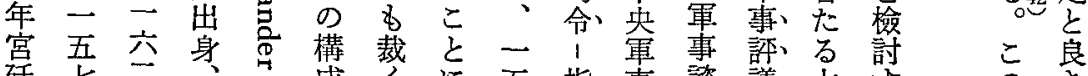

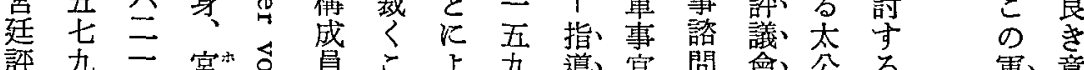

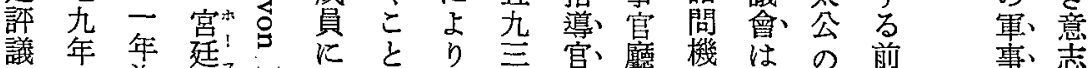

官 1 迄 財

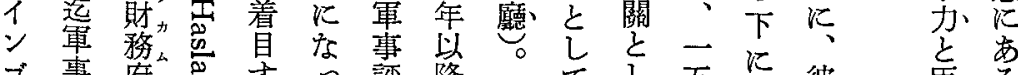

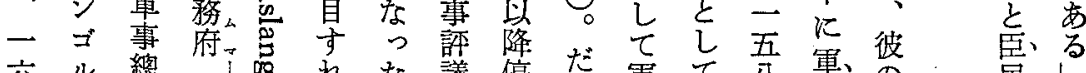

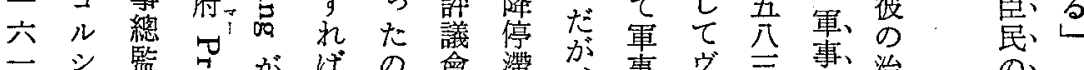

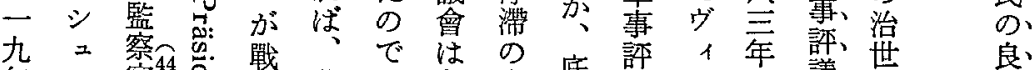

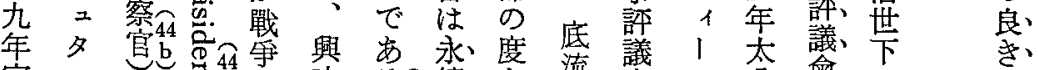

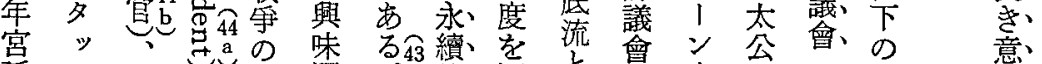

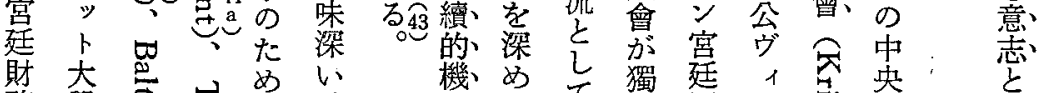

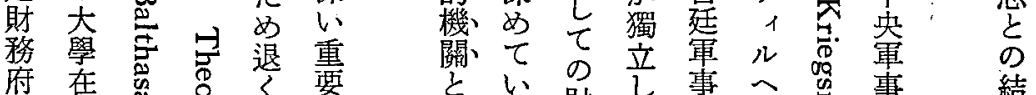

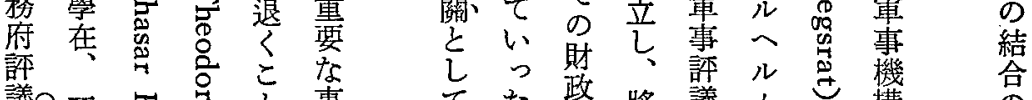

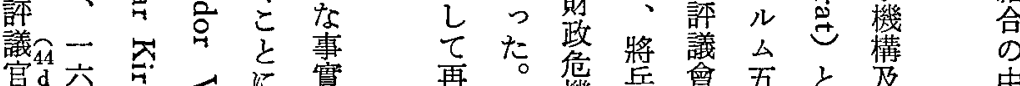

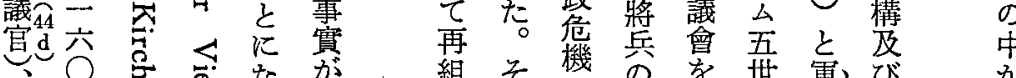

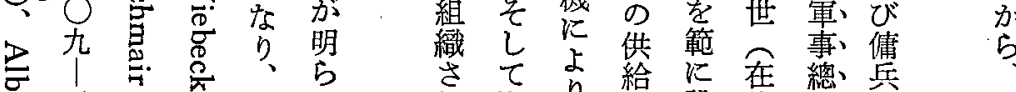

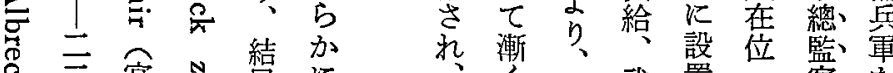

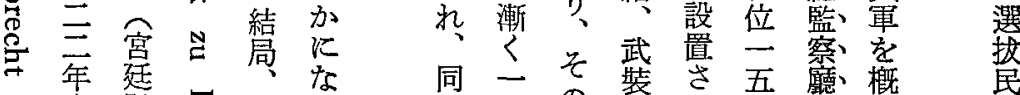

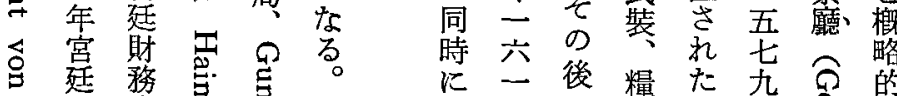

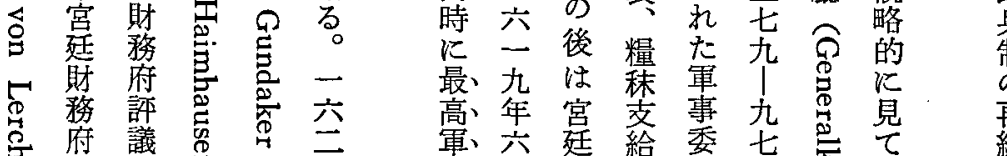

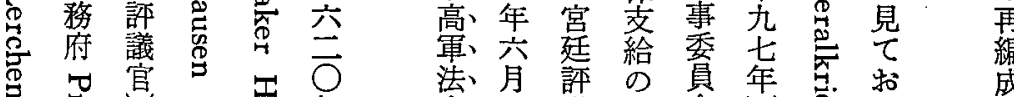

亮苛宦

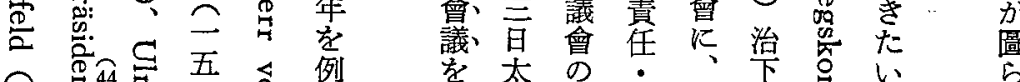

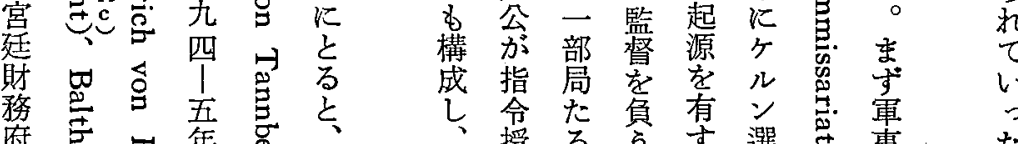

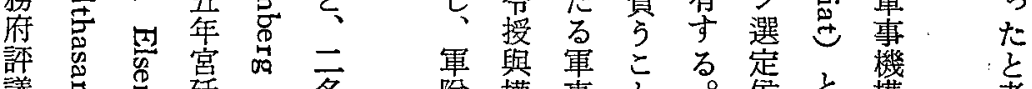

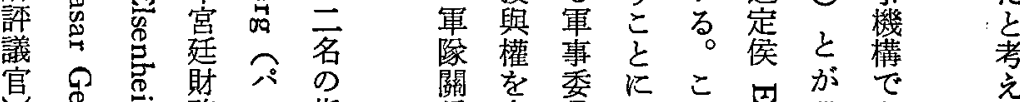

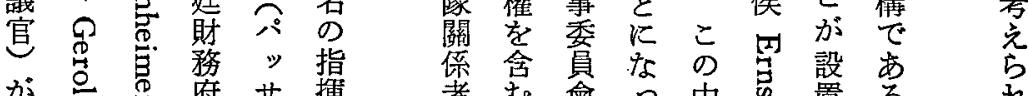

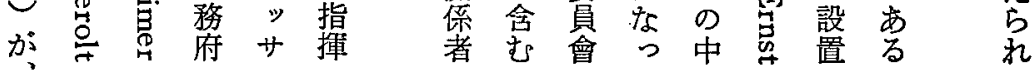


務

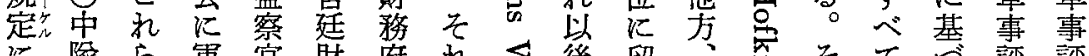

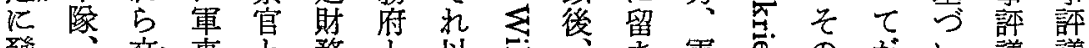

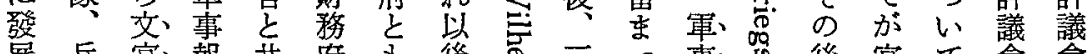

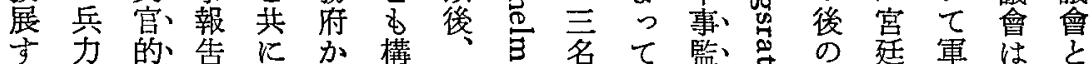

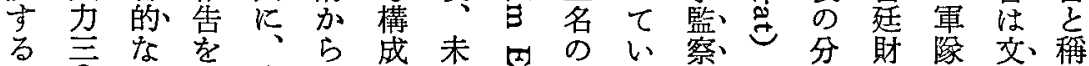
勒 中 な惯引貝た带軍た官と離務に官せ 勤 $\bigcirc$ 央し際きの明名事。滛政府對官ら

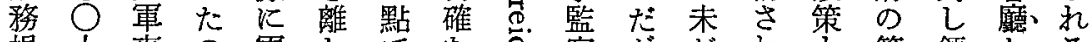

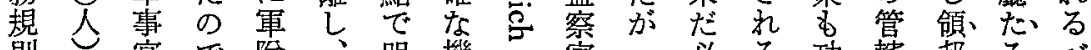
則 官で陵、明機へ官一必る功轄 邦、る心゙ II の廳むに擔確能三六ずこ市君宫き

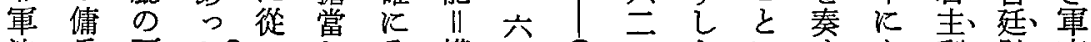

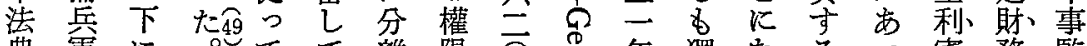

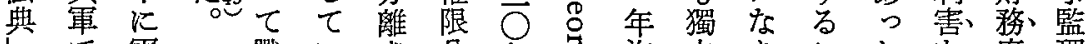
で軍戰いさ分年品迄立り竞府理

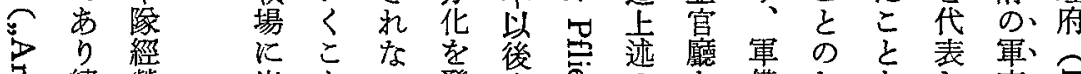

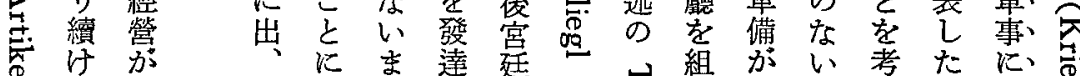

们

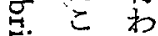

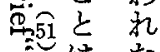
澊、疑賞 守 以時 老得寞

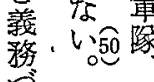
讨态会

まはわ ず俯汿

太艘

公就軍

忠海圭

蛽虽务

仕?連

克後 箸

彼後單

にの

提 軍” 雾, 㨁 务服又榢

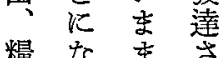

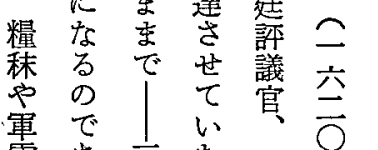

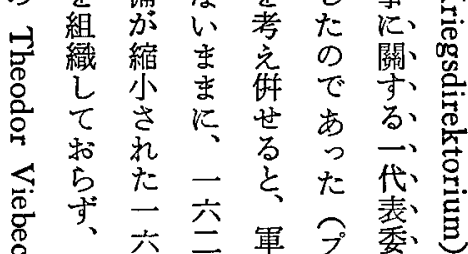

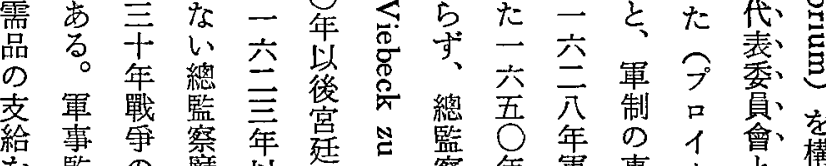

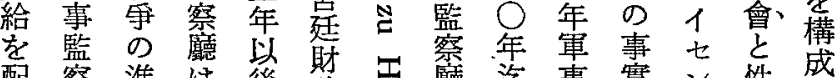

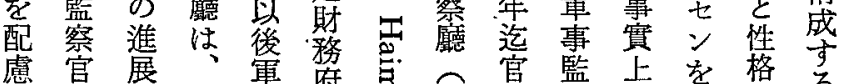

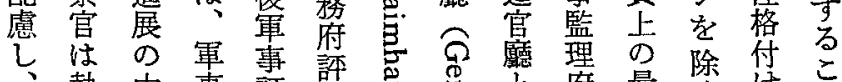

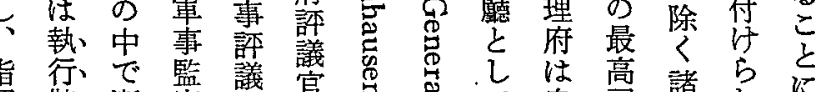

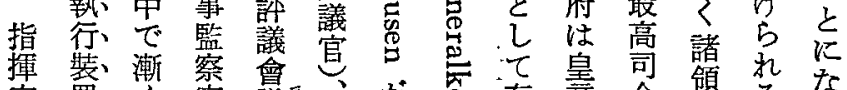

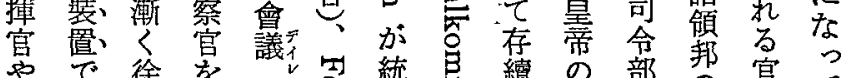

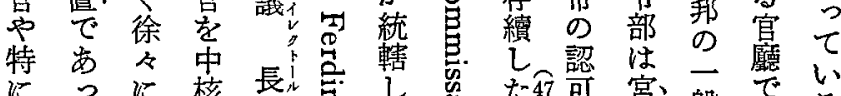

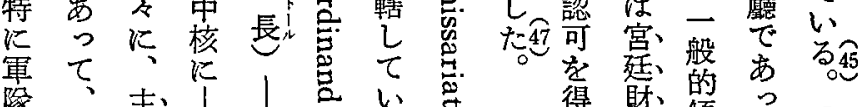

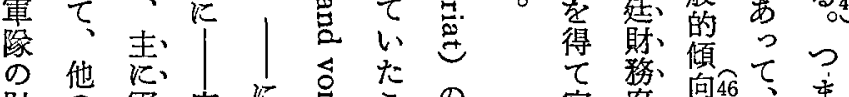

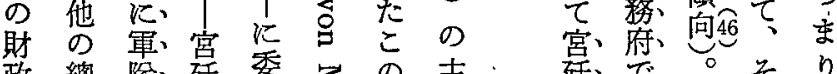

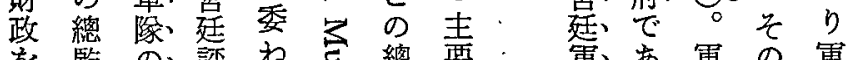

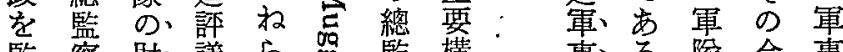

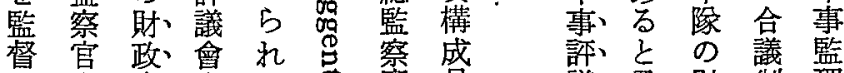

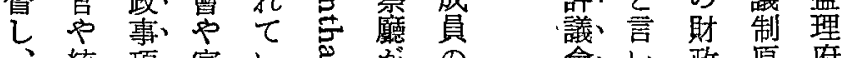
統項、宮い芑加会、政原府 
查 ン 所

閱 $卜$ 管

さ裁 區

设

る 所

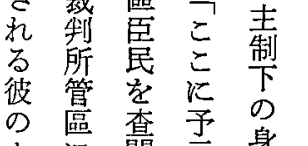

亦煘示

居省芯

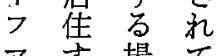

$\checkmark$ 場元的

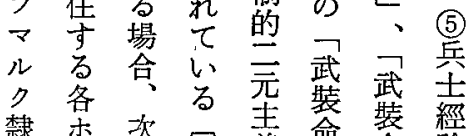

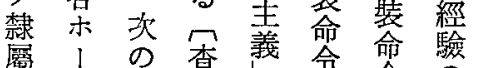

屬り 如䔔

を文き

彼儿命委

らク命 員

9 領 權 達

面盖索有

椡守

蹎郎 卜

權 占裁

余方、制

の歸 彼所

委屬 5 管

員林區

達る

の者 $\vdots$ 行

面派哲

前交占引

に書にン

率晏課卜

心提さ裁

る出机制

こした所

子、余管

を各の區

求柰委 農

め 1 往民

欲フに乃

ᄂ $、 \begin{array}{ll}\text { 至 } \\ \text { 至 }\end{array}$

まり、

床領賞 ⺊

查街敦裁

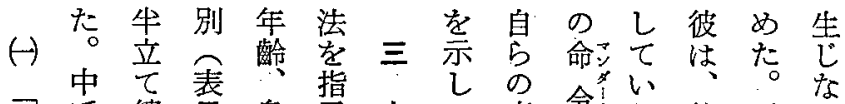

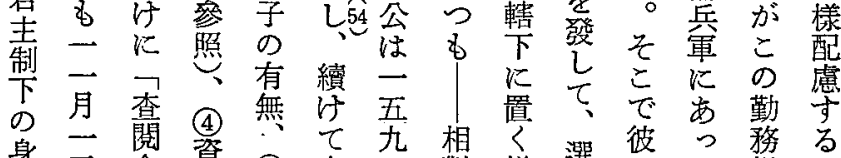

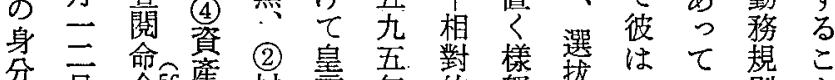
白命敂村帝年的羕拔はて瞡こ

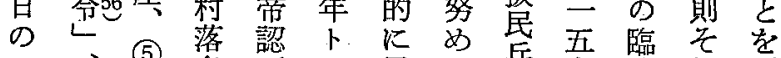
名可几早た兵九機れ誓 (3) 卡防疲で篮四性自約 完:衛整市基父命䀧方 全愛を茄る?゙ヴ令彼こ が二無、へ的脫そ領儿統俯号

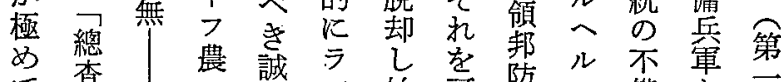

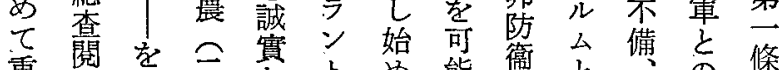

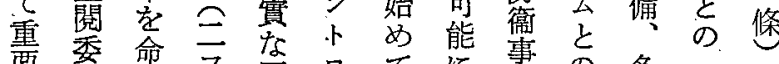

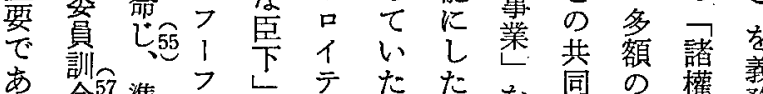

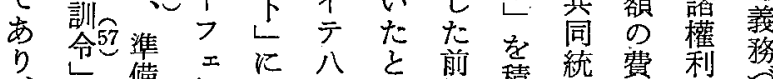

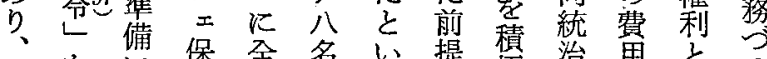

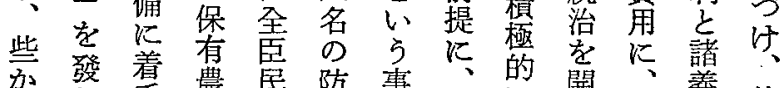

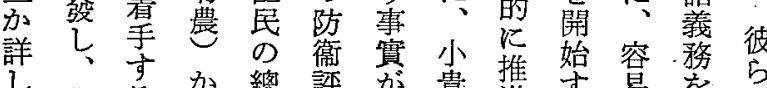

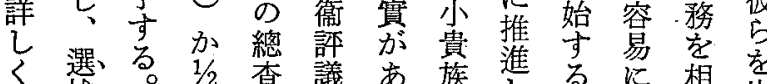

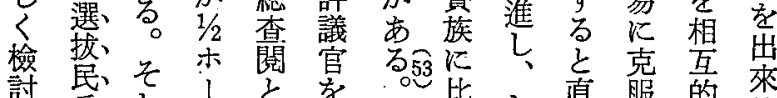

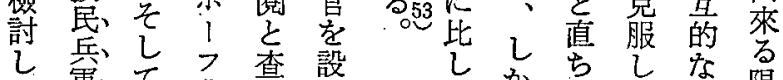

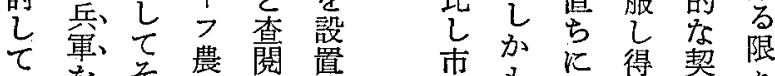

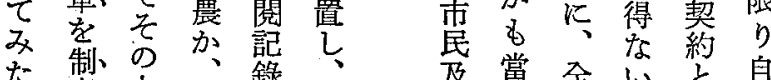

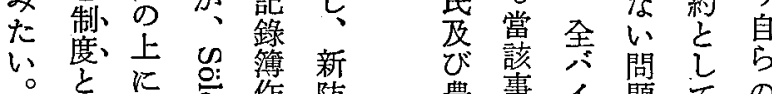
農囊1題元の

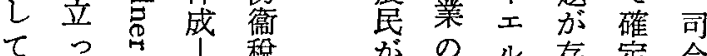

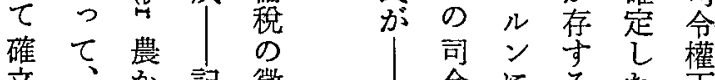

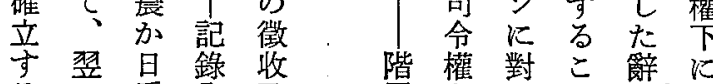

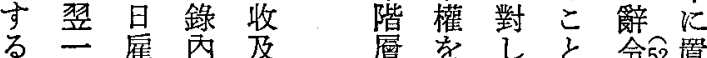

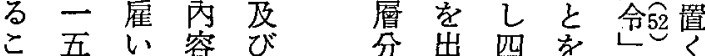

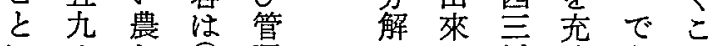

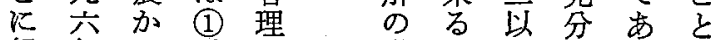

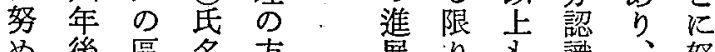

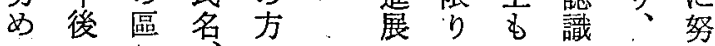


を翌しラ 認 理

命年たンめ解 史

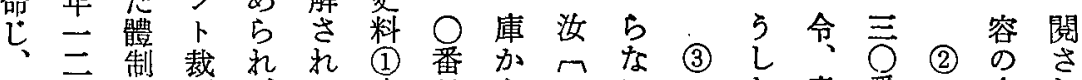

こ月は制、る中目ら、"意番命れ

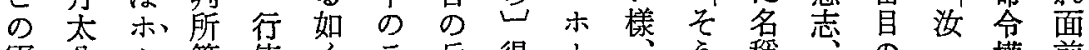

軍公小管使々

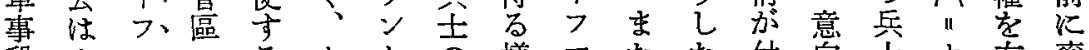

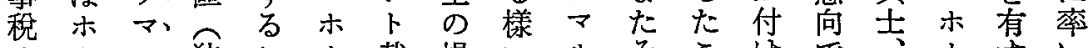

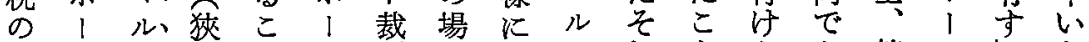

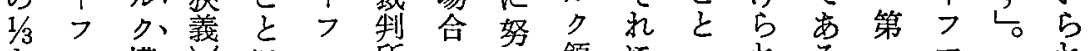

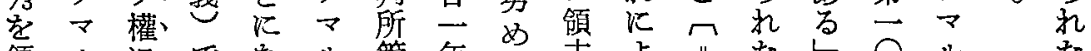

領ル に宾地 る

與主裙、方

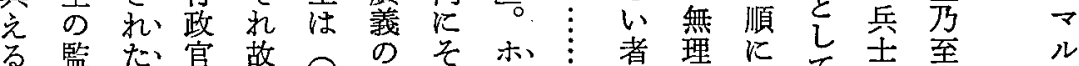

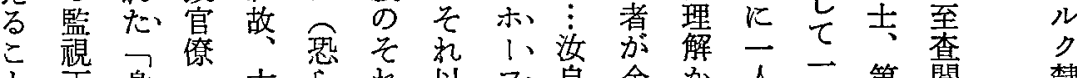

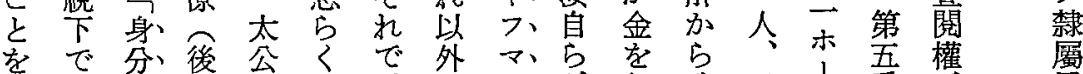

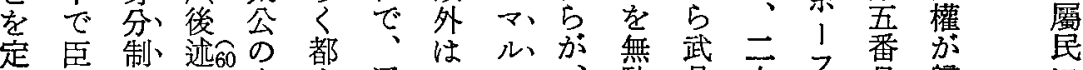

五 的、查 市通二只、䭾具人、

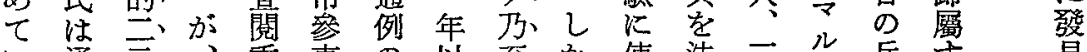

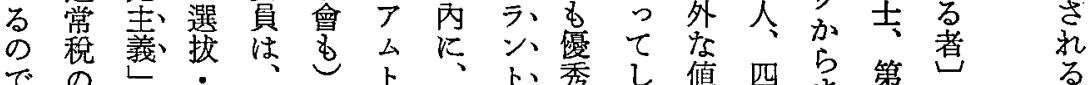

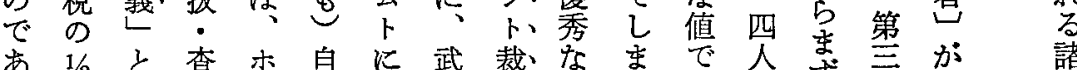

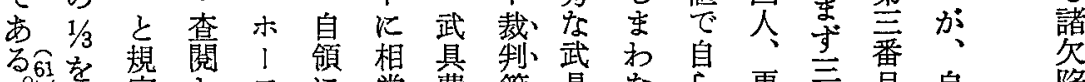

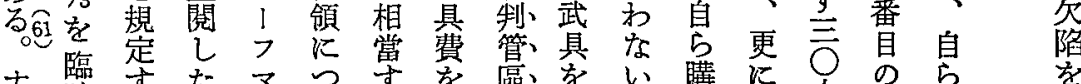

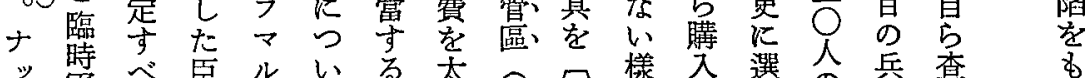

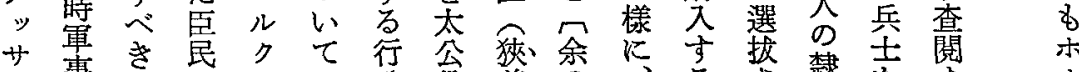

伯稅 の

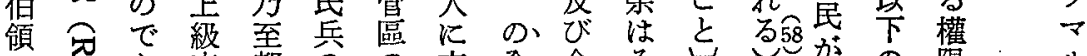

に范市香 都 の

比 器 。

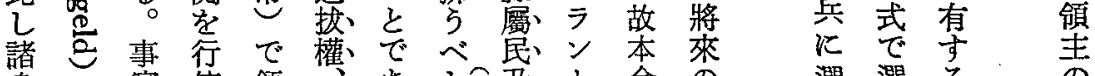

身々 寊 使 領 查る

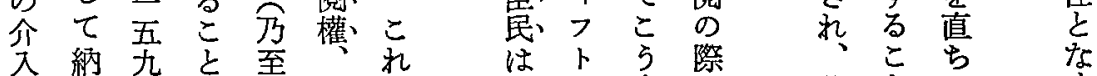

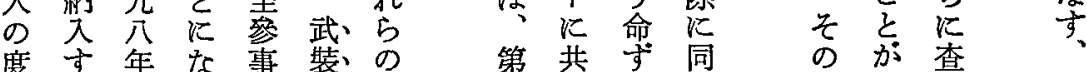

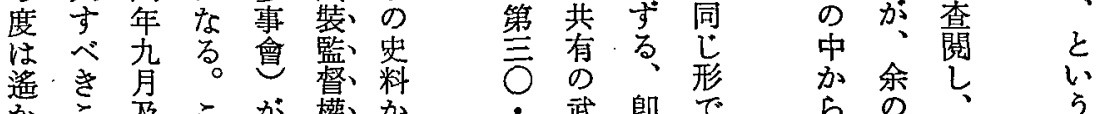

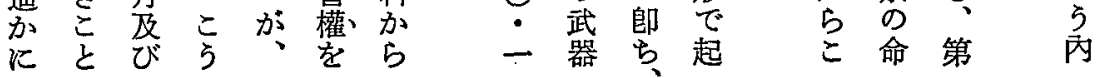


常業と施省

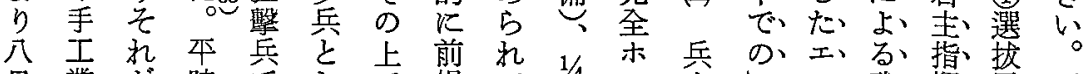
日業が時でし で提て

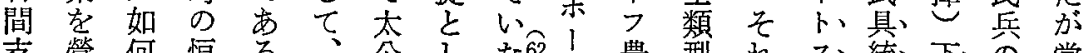

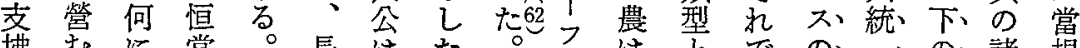
拂むに常。長はた黄はをでの、、の、諸䚈 心權負的步槍一上年農、農㐌涵化領贸定

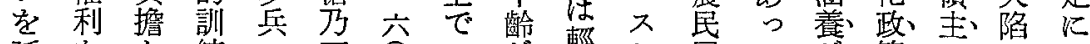

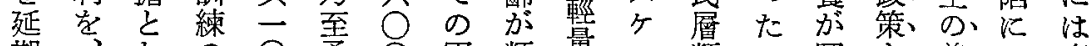
期、なの

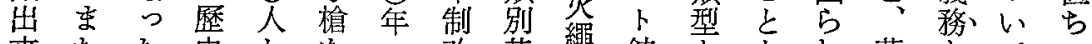

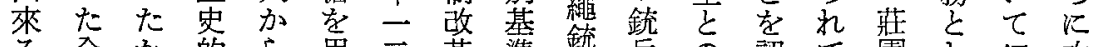

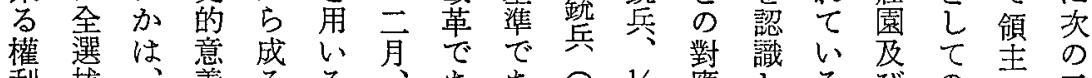

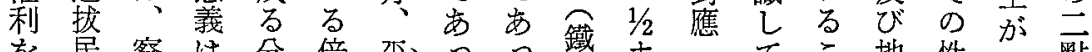

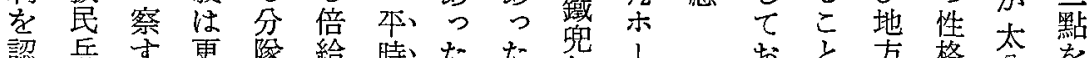

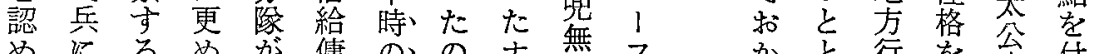

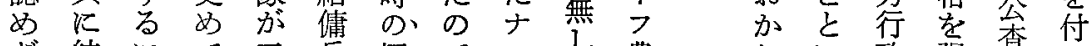
ざ結にて二兵恒でッし農称笅强眮け る 婚 余論了架常あサかは、管了委加

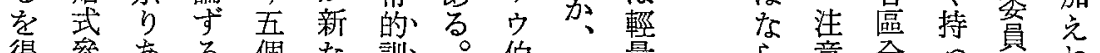

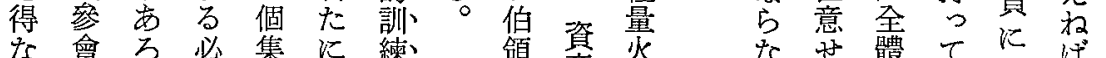

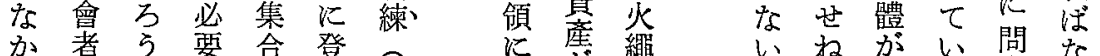

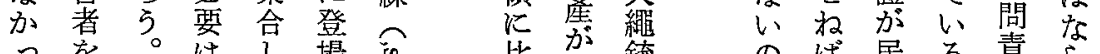

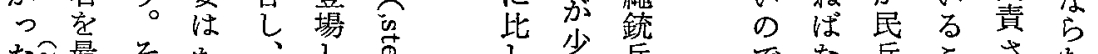

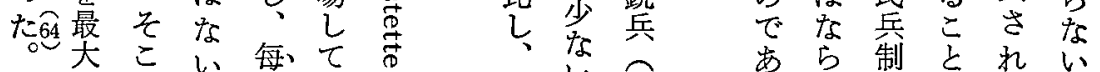

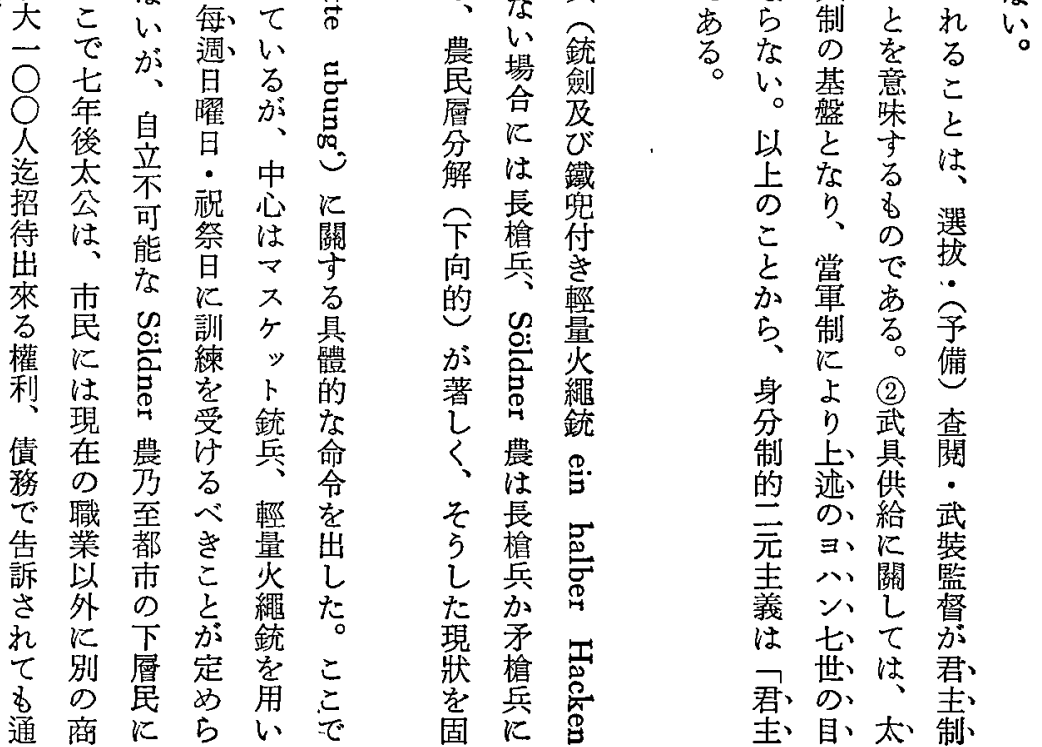




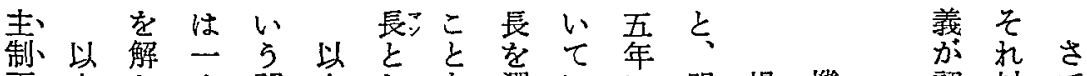

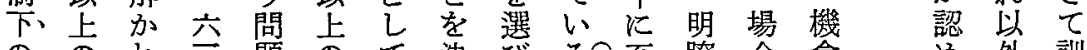

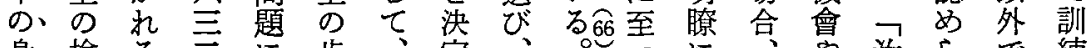

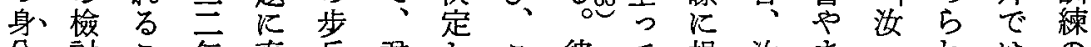
分討こ年直兵群しこ彼て規汝ま杂は，

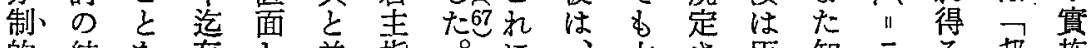

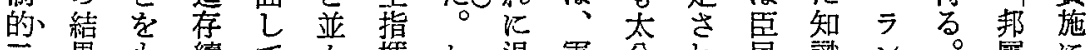

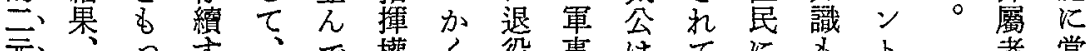
百、湆て

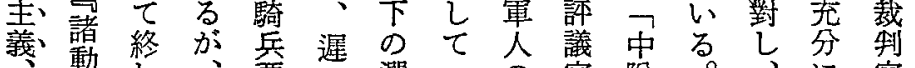

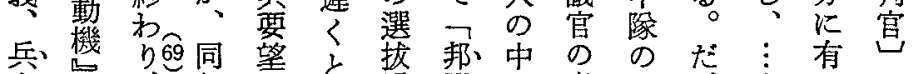

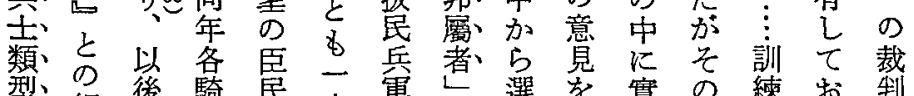

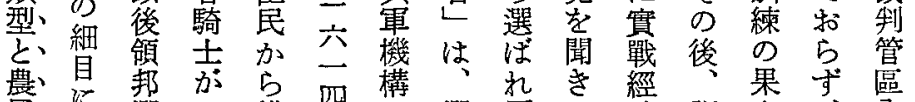

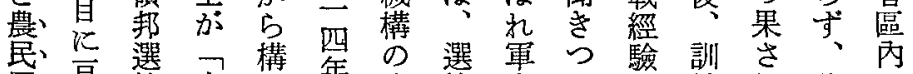

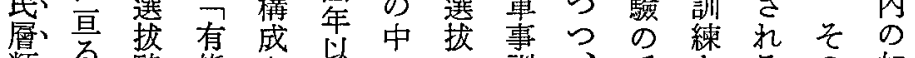

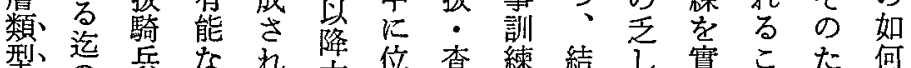

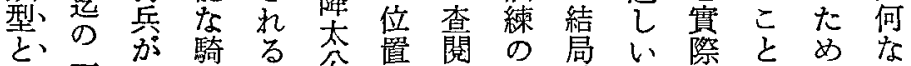

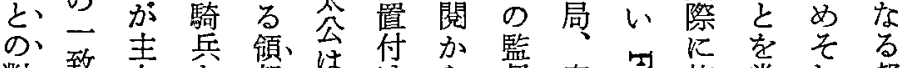

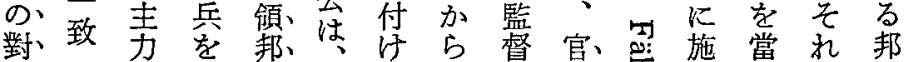

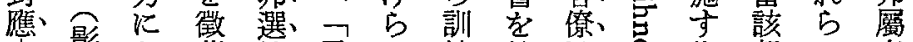

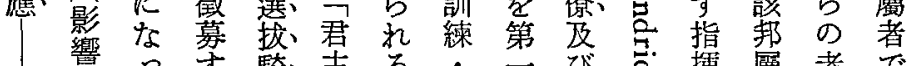

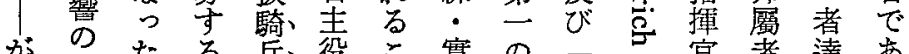
が强たる兵役こ實のつ官者達あ

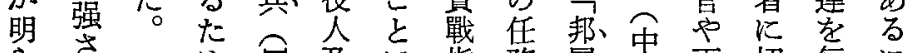

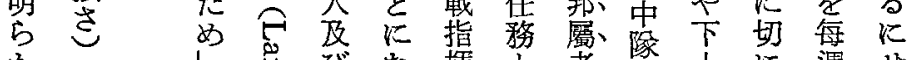

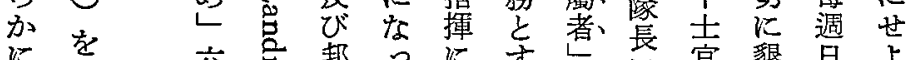

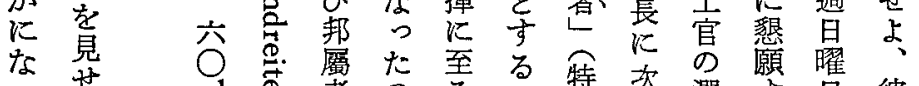

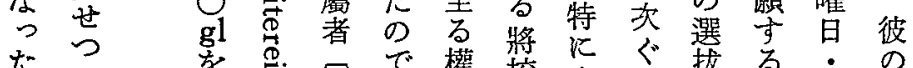

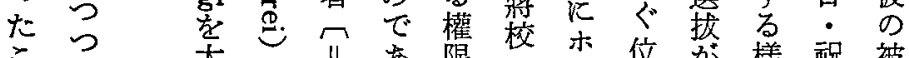

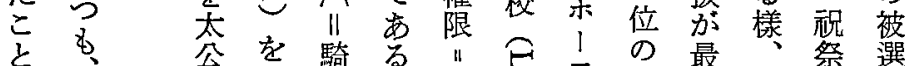

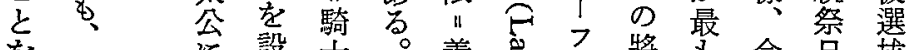

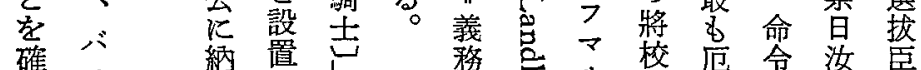

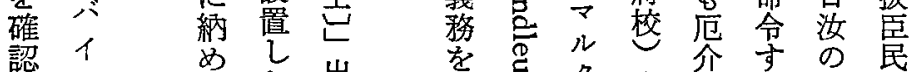

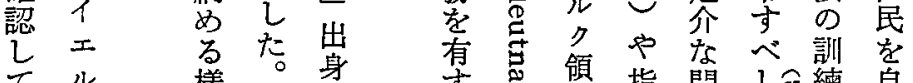

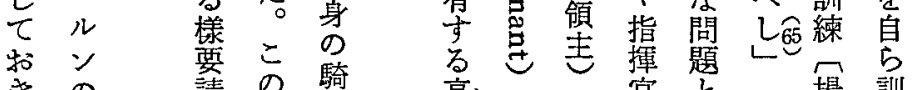

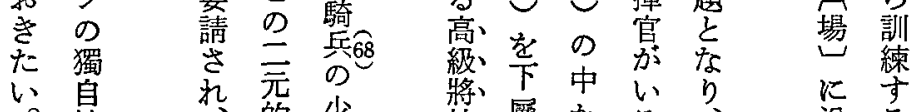

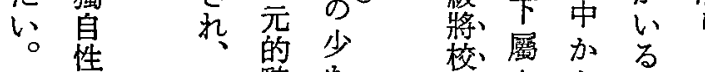

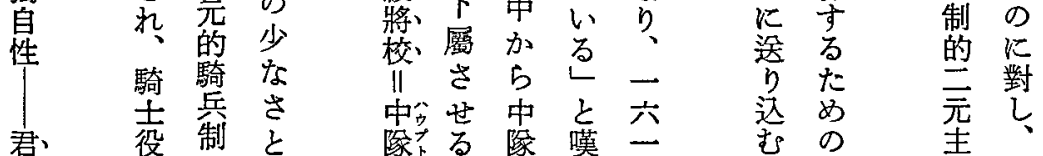


ドイッ絕對主義的領邦における軍制

〔表III〕パイエルン選拔民兵軍兵力（1600-50年）

\begin{tabular}{|c|c|c|c|c|c|c|c|}
\hline \multirow{2}{*}{ 年 度 } & \multicolumn{2}{|r|}{ 兵 } & 踦 & 兵 & 合 & 計 & \multirow{2}{*}{ 備 } \\
\hline & 中榢 & 兵 力 & 中隊 & 兵 & 中䠔 & 兵 力 & \\
\hline 1600年 & - & 22,000 人 & 0個 & $0 人$ & - & $22,000 人$ & $\left(\begin{array}{l}\text { 太公直轄領: } 14,000 \text { 人 } \\
\text { ホーフ }\end{array}\right.$ \\
\hline 1607 & 20個 & 5,000 & 0 & 0 & 20個 & 5,000 & 侓兵 : 1,000 \\
\hline 1611 & - & 一 & - & - & - & - & 總兵役義永者 : 120,235 \\
\hline 1614 & - & 15,314 & - & 1,099 & - & 16,413 & 總兵役義務者：134,910 \\
\hline 1615 & - & - & 15 & - & - & - & \\
\hline 1618 & 33 & - & 6 & - & 39 & 一 & \\
\hline 1622 & 41 & 15,948 & - & - & - & - & 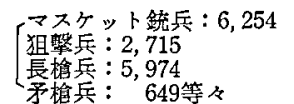 \\
\hline 1636 & - & 一 & 一 & - & - & 一 & 總兵役義務者 : 54,609 上上 \\
\hline 1638 & 29 & 10,333 & - & - & - & 一 & \\
\hline 1641 & 40 & 15,553 & - & - & 一 & - & \\
\hline 1643 & 32 & 12,137 & - & - & - & - & \\
\hline 1648 & 16 & 3,237 & - & - & - & - & \\
\hline 1650 & 32 & 12,137 & - & - & - & - & \\
\hline
\end{tabular}

- Karl Staudinger: Geschichte des kurbayerischen Heeres insbesondere unter Kurfürst Fer. dinand Maria 1651-1679, München, 1901, S. 68f., 86, 108-112, 314-317.

[表IV]ハイェルンの三十年戰学軍事費

\begin{tabular}{|c|c|c|c|c|}
\hline $\mathrm{Nr}$ & 支 & 項 & 支 出 額 (fl) & 總計比(\%) \\
\hline 1 & \multicolumn{2}{|l|}{ 將官及び幕僚 } & $1,122,805$ & 1.9 \\
\hline 2 & \multicolumn{2}{|c|}{ 軍事監察宫, 軍事評議官, 畫記官 } & $1,043,187$ & 1.8 \\
\hline 3 & \multicolumn{2}{|l|}{ 「待命」將校 } & 147,682 & 0.3 \\
\hline 4 & \multicolumn{2}{|l|}{ 踦兵（龍騎兵も含む） } & $12,412,351$ & 21.1 \\
\hline 5 & \multicolumn{2}{|l|}{ 步兵 } & $24,462,276$ & 41.6 \\
\hline 6 & \multicolumn{2}{|l|}{ 硕兵 } & $3,979,769$ & 6.8 \\
\hline 7 & \multicolumn{2}{|l|}{ 兵站部 } & $6,042,037$ & 10.3 \\
\hline 8 & \multicolumn{2}{|c|}{ 民兵（„Landvölker“：選拔民兵及び戰時民兵） } & 691,612 & 1.2 \\
\hline 9 & \multicolumn{2}{|c|}{ その他の軍費, 使笁派遣, 諜報等 } & $2,107,685$ & 3.6 \\
\hline 10 & \multicolumn{2}{|c|}{ 表彰等 } & 109,070 & 0.2 \\
\hline 11 & \multicolumn{2}{|c|}{ 貨幣惡鑄による損失（1620－22年） } & $6,004,305$ 以上 & 10.2以上 \\
\hline & 總 & 計 & $58,816,724$ & 100.0 \\
\hline
\end{tabular}

- Sigmund von Riezler:Geschichte Baierns, Bd.6, 1508 bis 1651, Neudruck der Ausgabe 1903, Aalen, 1964, S. $171 f$. 


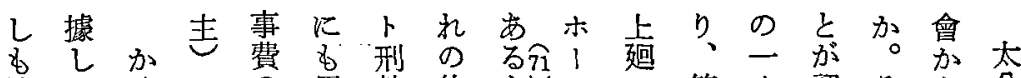

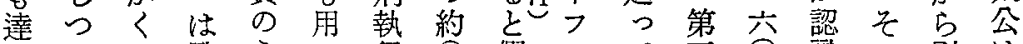
成つの戰らい行 $○$ 假マて言

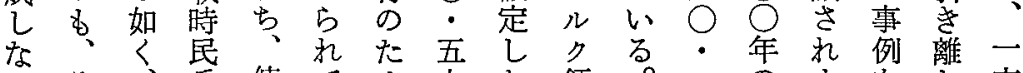

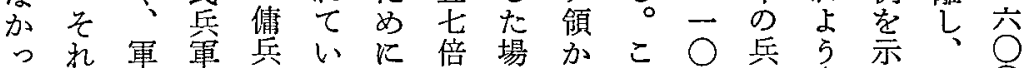

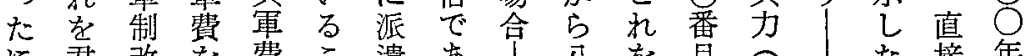

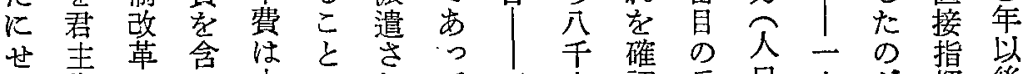
よ指

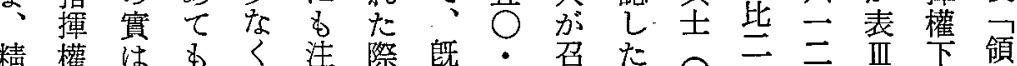

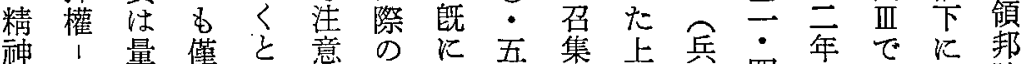

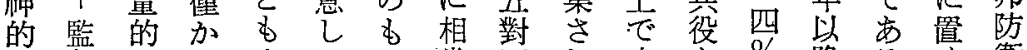

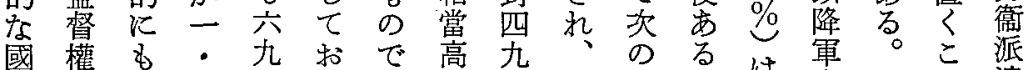

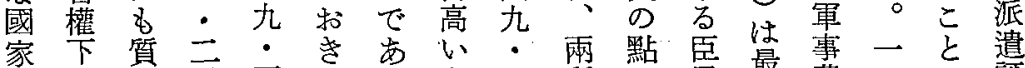

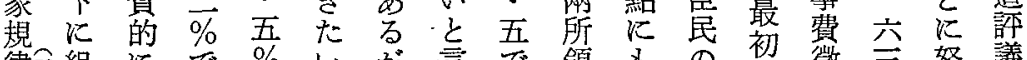

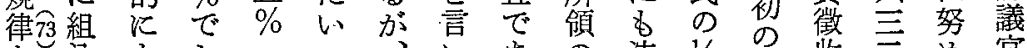

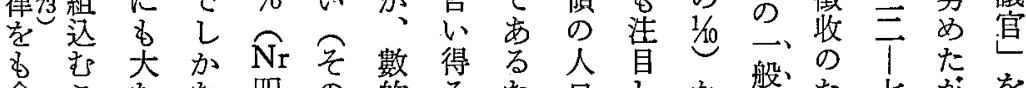
含こなな四の的るた台しか䚀た 七が

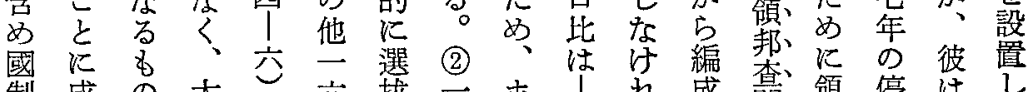

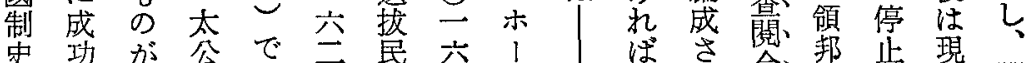

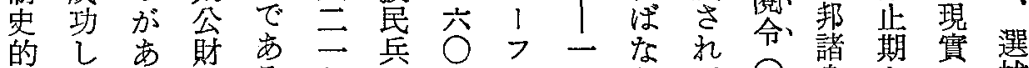
意た口政る年分七マ六らて二身を拢 義のたのの方侓年ルな分除ど民

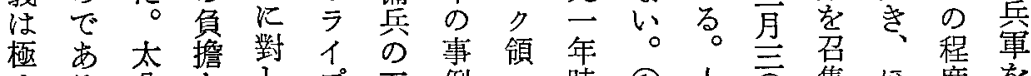

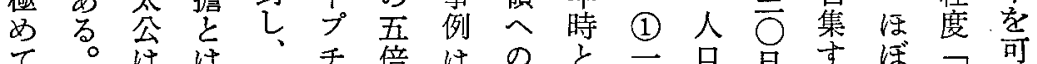

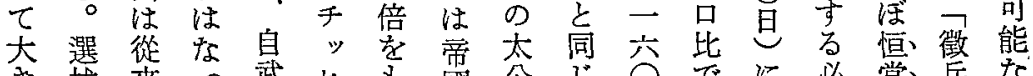
き拢來つ武故國公じ か民のて 裝戰占都權で

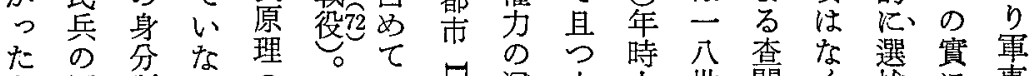

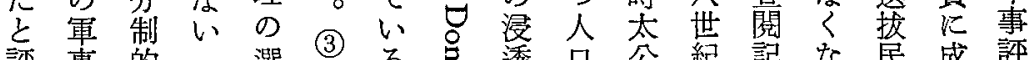

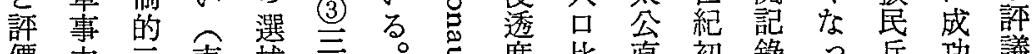

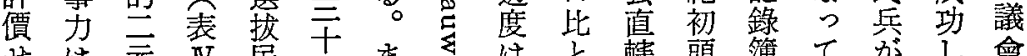

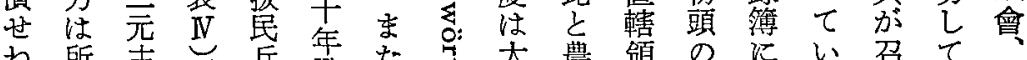

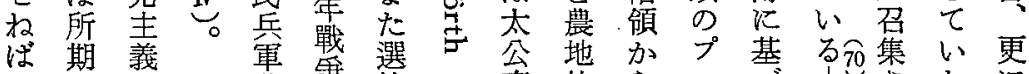

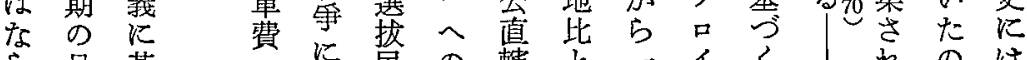

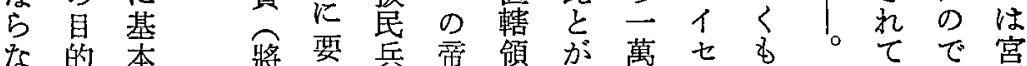

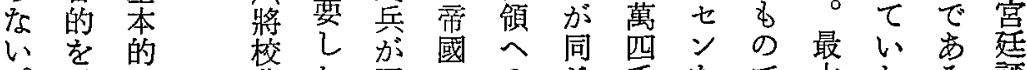

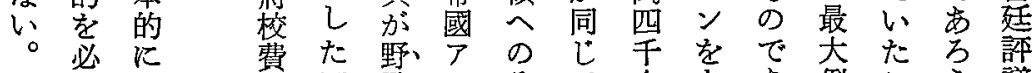
ず依苦軍戰八そで人文市例こう議 
討っ他れ至儿世敉 心過領以侯騎と領

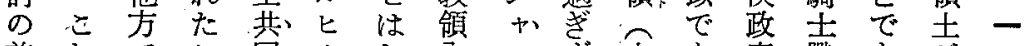

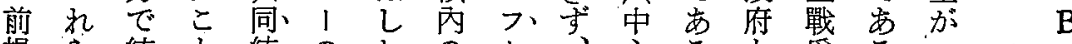

提 ら 統 と 統、の

し國者あ者にで

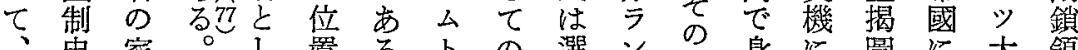

史家。し置るトの選ンた身に滴に大領

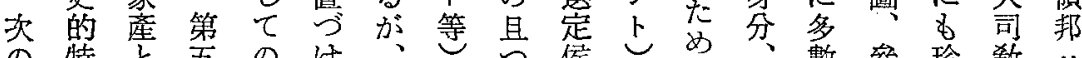

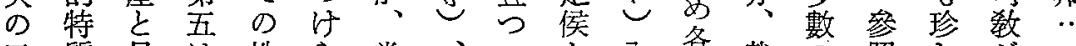

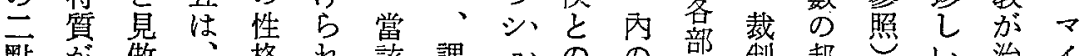

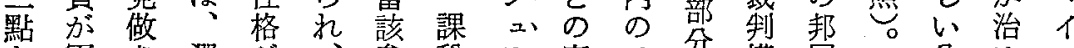

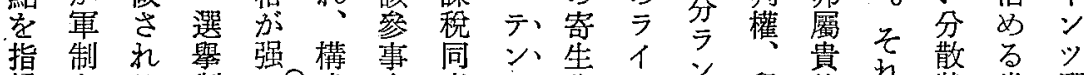

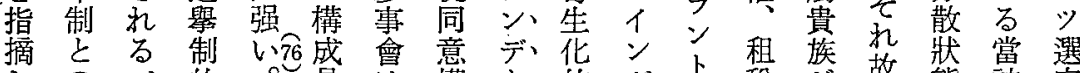

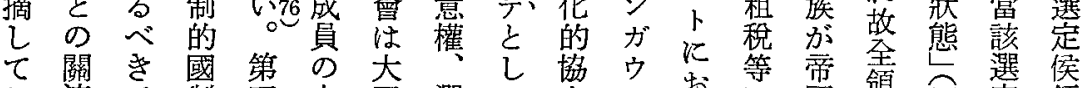

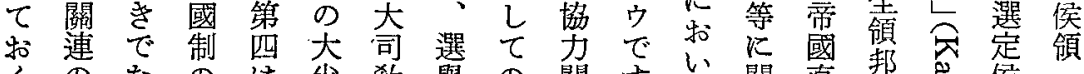

こ中な の

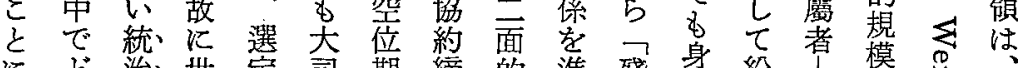

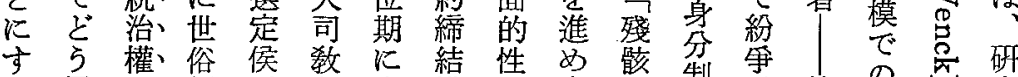

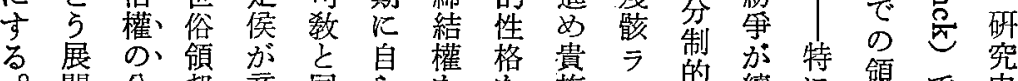

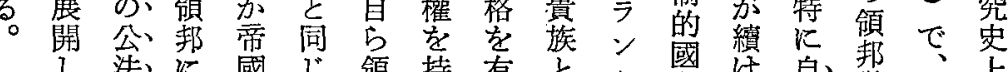

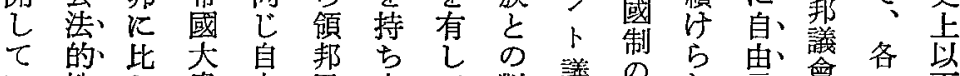

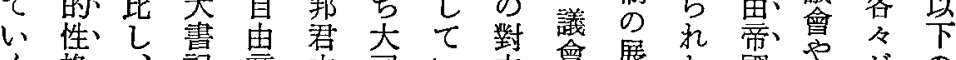

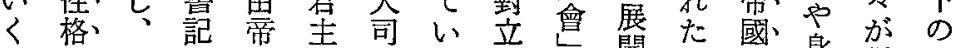

かが一長國權 たを教た集こ騎分强國

をょ方で騎を統こ强二阻を裚制い制

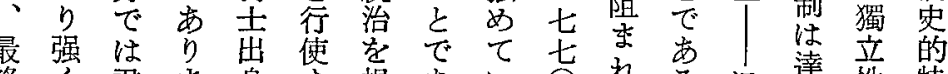

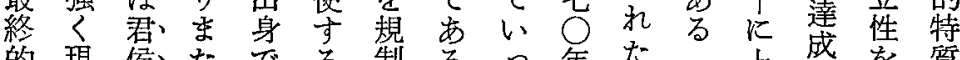

的現侯たでる制る。年た。桌成学質

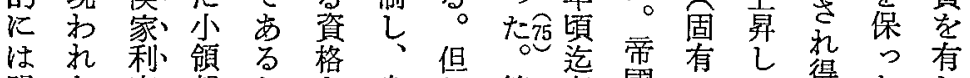

明た害邦た竞身し第存或の續意つなた

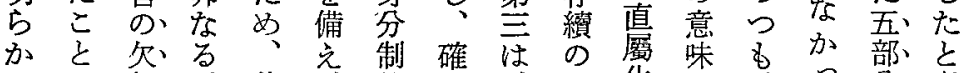

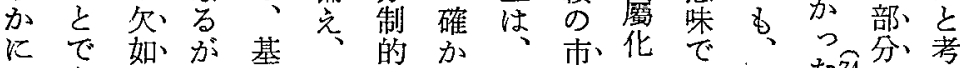

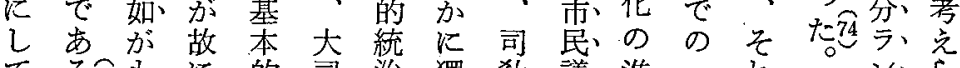

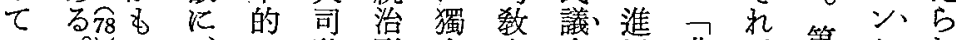

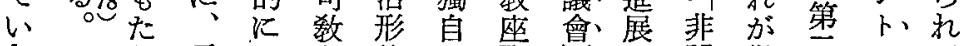

巳 5 帝

たさ國へ、共高堂が逑鎖底、分き

、杂政心灌轄參召机領华農裂た

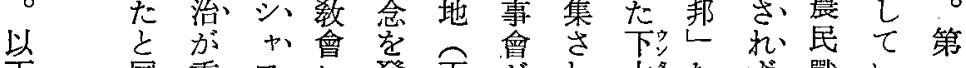

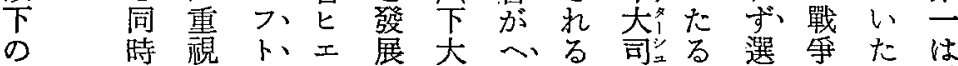

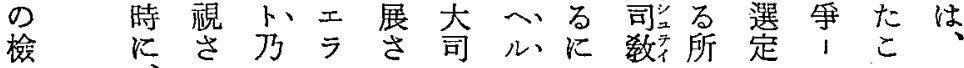


委 世 寸

衫㫐紀る二厶，行政にぜ第方生侯 (2) (1)

ら年以

己 迄選フ

乙定 ラマ定代等原法彼敎㕣奇る機二口。

た貴は

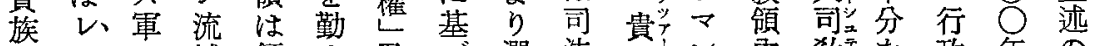

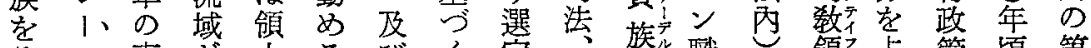

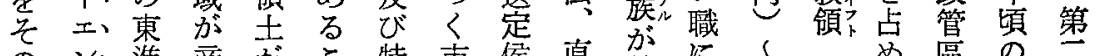

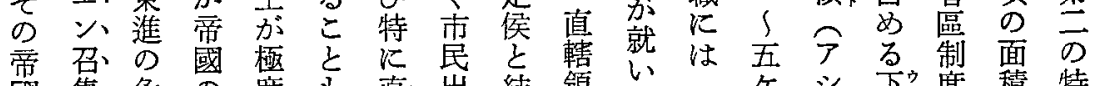

國集危の度过直出結領たっケシ 只度積 特

直軍機東に彼轄、身合及た諸

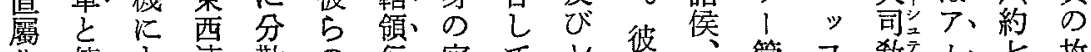

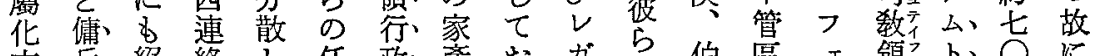

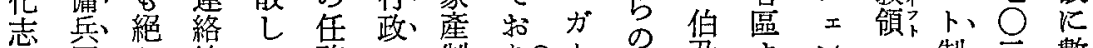

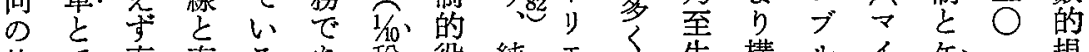

故で直南るあ税役純エく生構ルイケ、 $\mathrm{km}^{2}$ 規

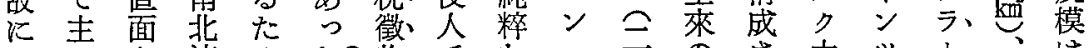

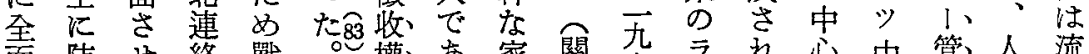
面防せ絡 戰 權市家閶名 ラれ心中管人流

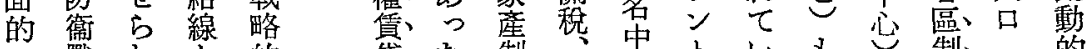

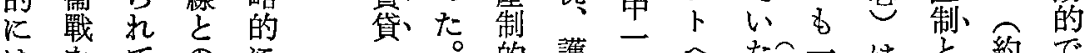
はをて

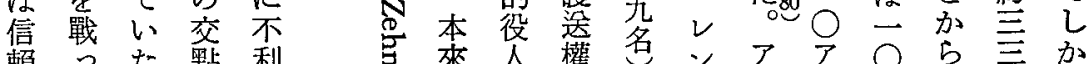

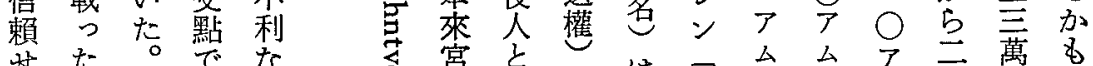

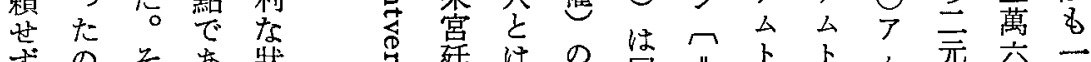

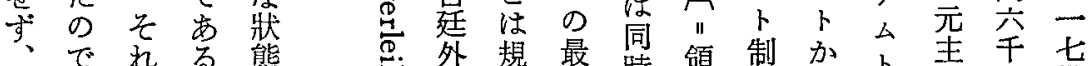

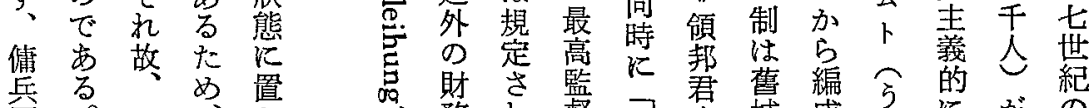

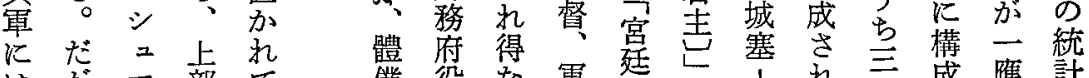

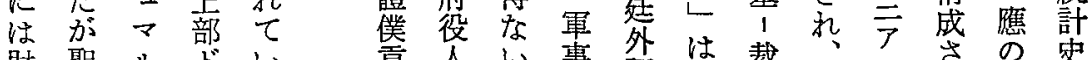

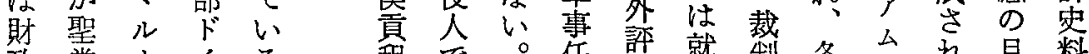
政堂力イる租で。任評就制各台れ目料

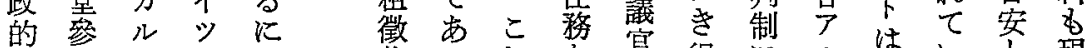

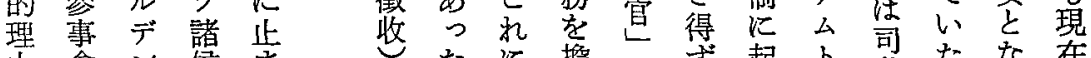

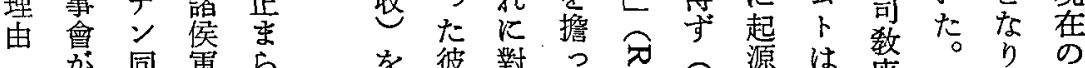

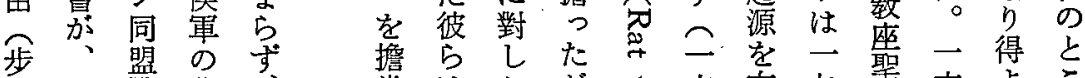

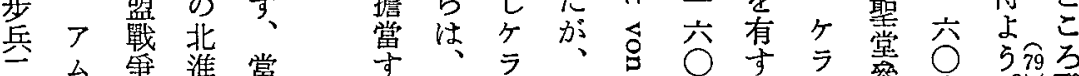

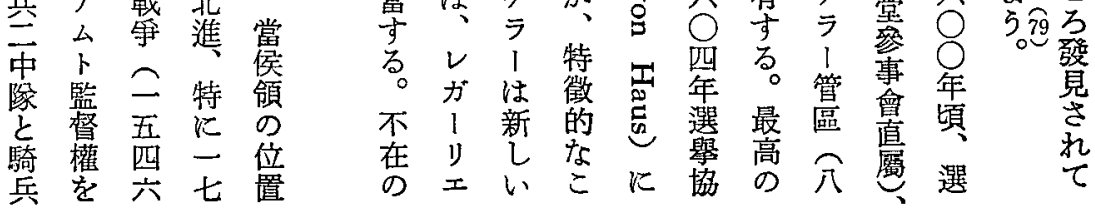




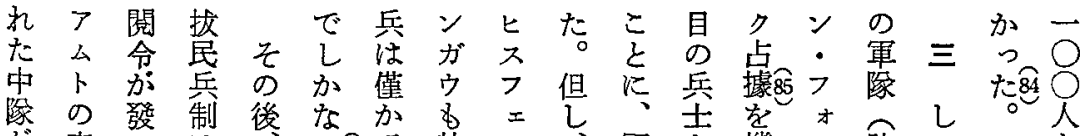
萣查世發制

退阔 5 着準

將錄た纪

兵簿 時 展 ヴ

の 分開 才

中明以さル

少市せ

らすの 5 ガ

選る諸れン

ば 如 點 てク

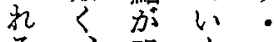

亲各朐く

階宁少とン

級么、に.

のトな 5 ダ

幹每つの儿

部にた它

蚶司か力ル

中命 らル

陵部でヴ

長㤎古方

讨。派 4

5 (1) 派

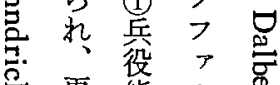

字更役態

西㐒選 在

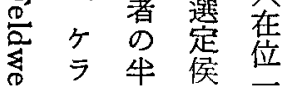

苛管 嘍 領 五

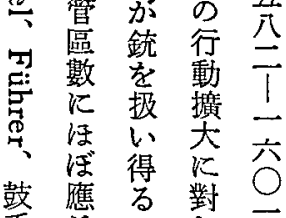

手导こし年

軍數文五

佥元 特

人措及潠䩦配こ亦䈍當

、軍要機 ン防少

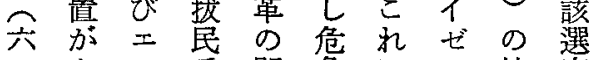

- と儿兵開急にン地定

八 57 窝始の對シ位侯

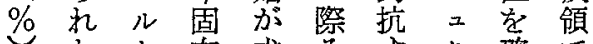

た卜有求々卞夕確で

でこののめのるム保も

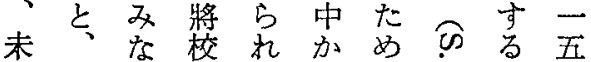

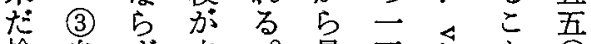

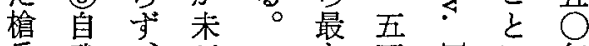

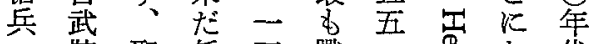

裝聖任五戰云怘な代

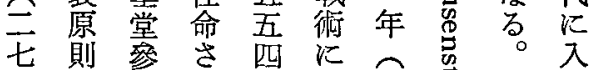

士則參さ四机年長更节以各

人武事记年長更产以る

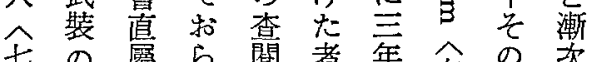

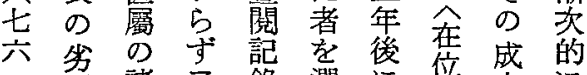

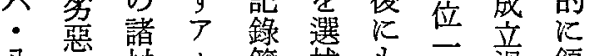

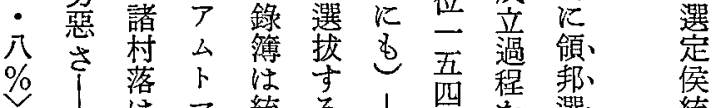

が例查

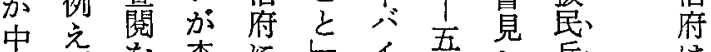

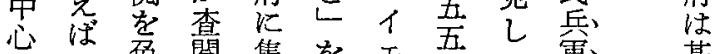

で叒閱集を学 年て軍基

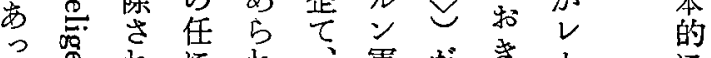

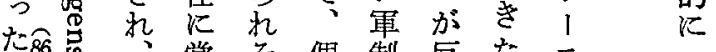

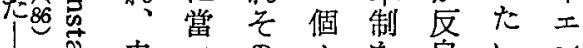

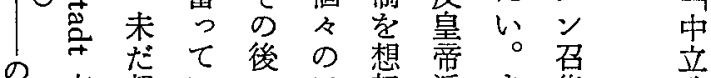

市邦いののア起派ま集政

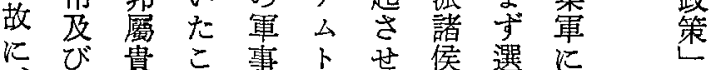

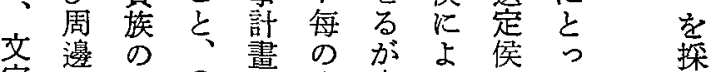

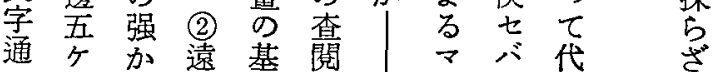

㹂艺 (2) 九 治

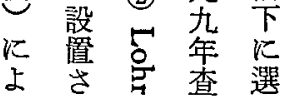

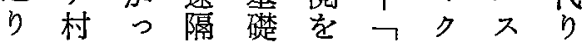

出でた の 發命第 デデ

發は 


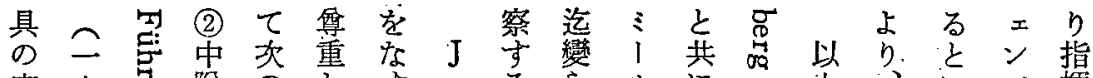

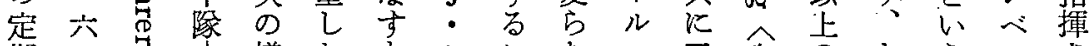

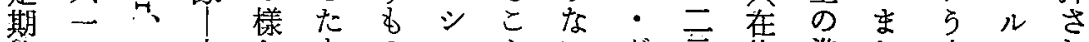

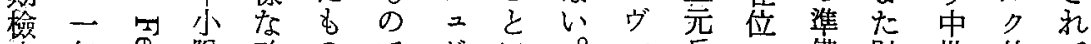
查年哭榢改のでヴに。丁兵二備財世伯て

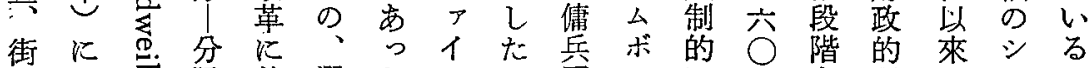

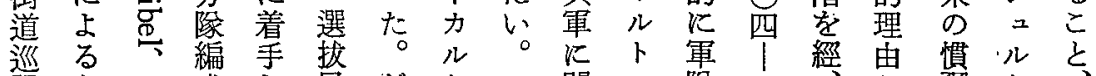

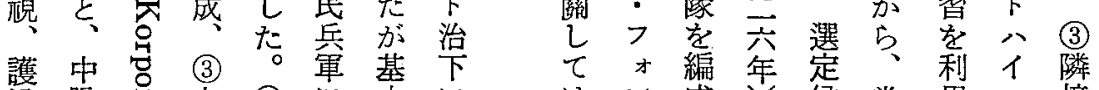

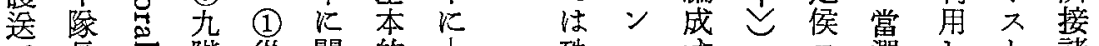
で長市階從關的| 殊

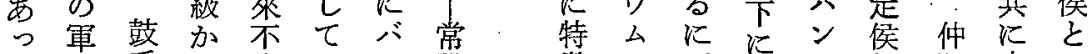
た務手 5 定は1設徵シ至選・領間查の

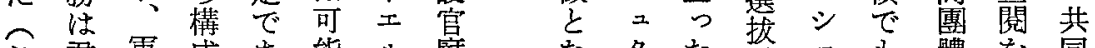

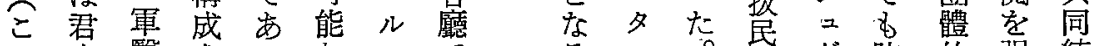
の主醫さっなンでるッ兵ヴ防的强統 中役行た限とは點卜こ制了衛な行治

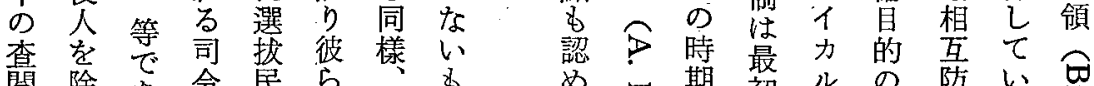

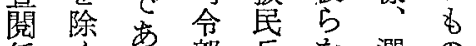
任々 る89 部 兵索選 の 務 全 889 の 排定 の

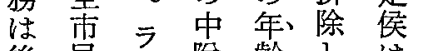

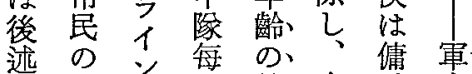
魀 查、唯の 特、直、兵事 如 閱、方設定、接、寞 評、 <置化各 の 議 $\overline{7}$ 年

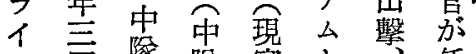
回隊榢筫上任

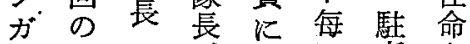

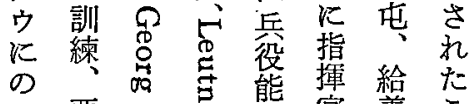

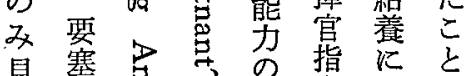

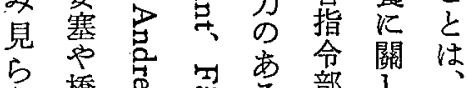

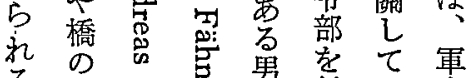

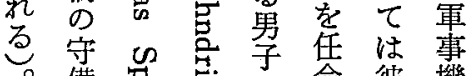

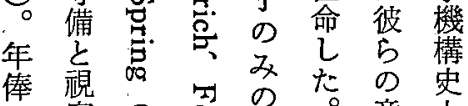

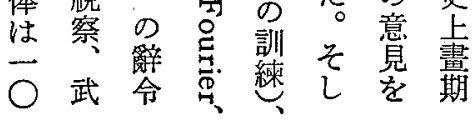

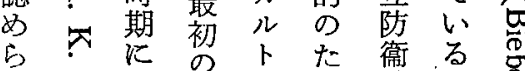

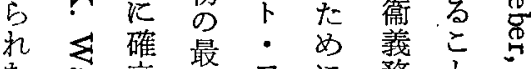

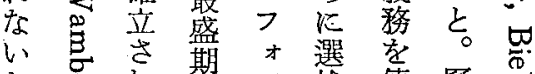

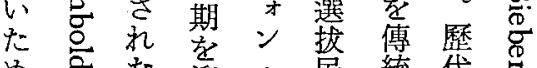

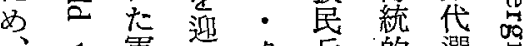

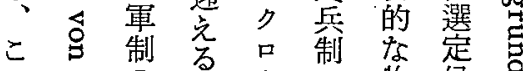

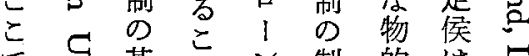
它基々 制的性

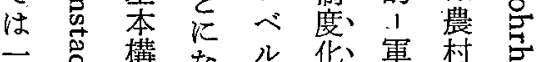

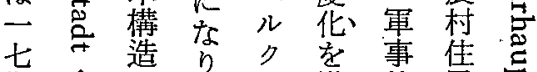

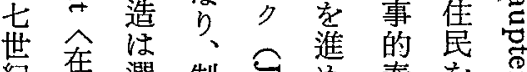

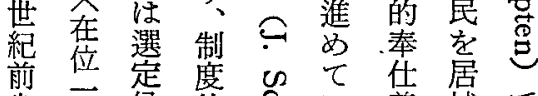

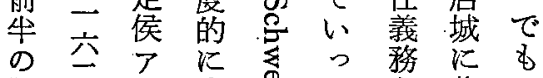

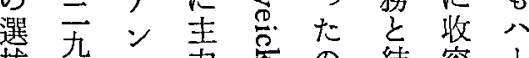
势先ぜ屴忘の結容

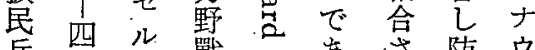

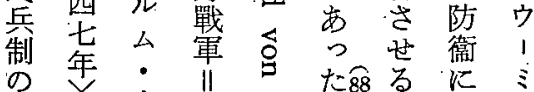

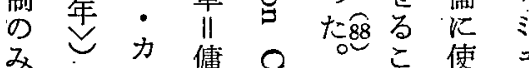

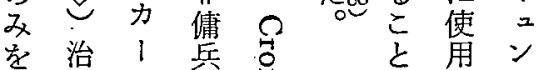

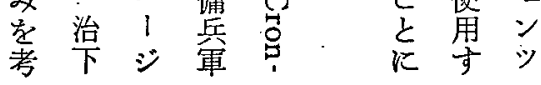


ドイツ絶對主義的領邦における軍制

〔表V】 マインッの中央官笪の年俸例 (1590/1627年)

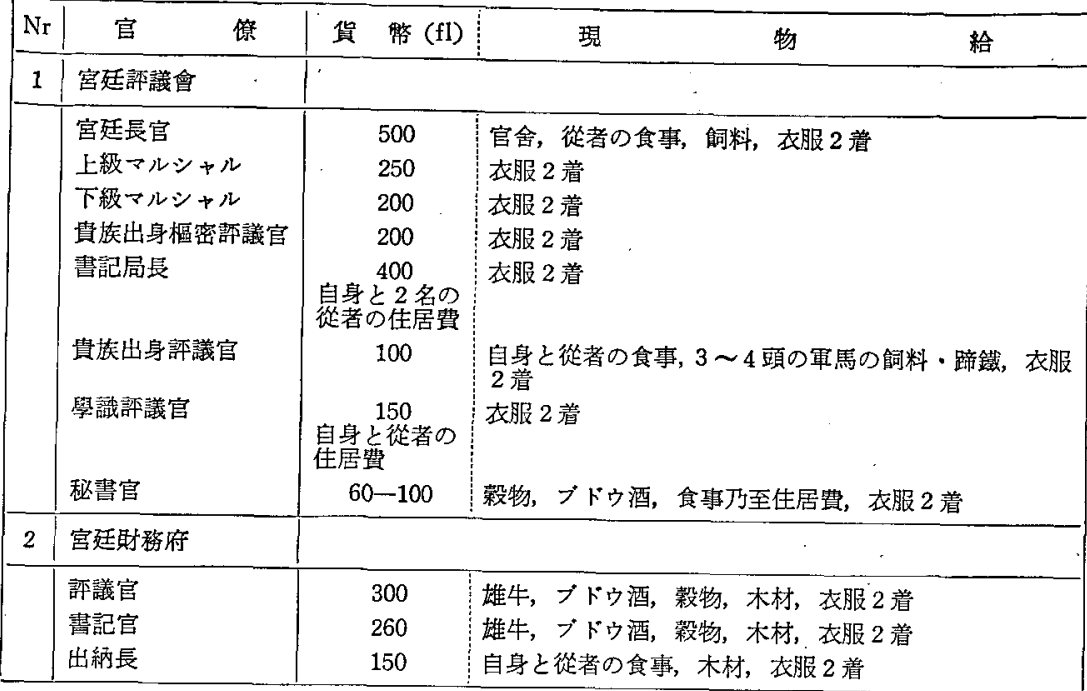

- Hans Goldschmidt : Zentralbehörden und Beamtentum im Kurfarstentum Mainz vom 16 bis zum 18. Jahrhundert, Berlin und Leipzig, 1908, Besoldungstabellen $5 . ⿹$ 作成。

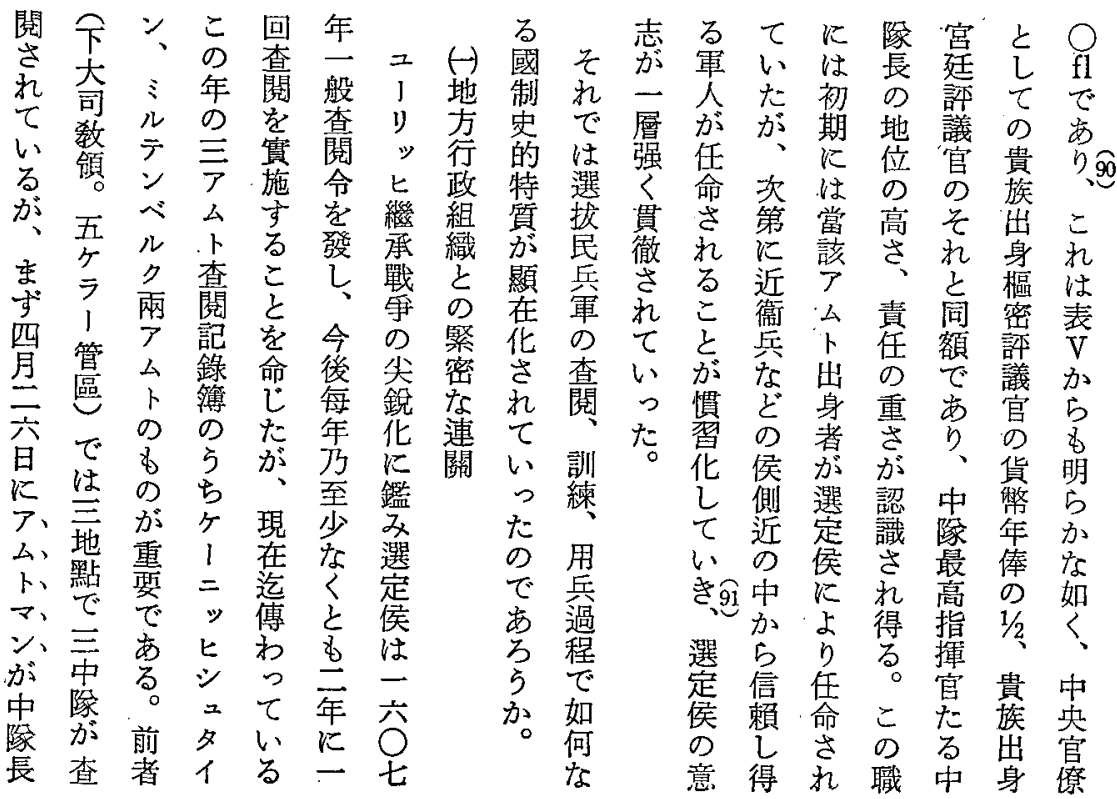


以中 $\bigcirc$ 成

弓の年る

許 傭 六程 定

可兵月 至侯

を窝に市領

口將 注年 内部

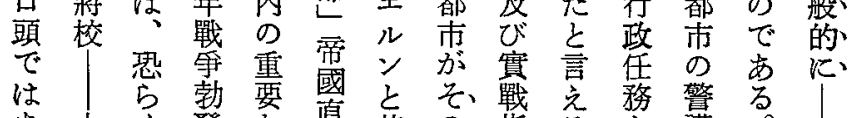

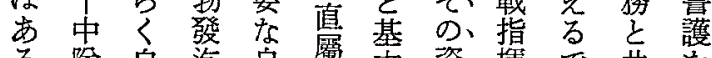

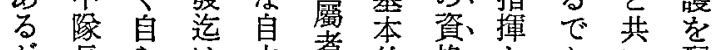

方長 5 は音者

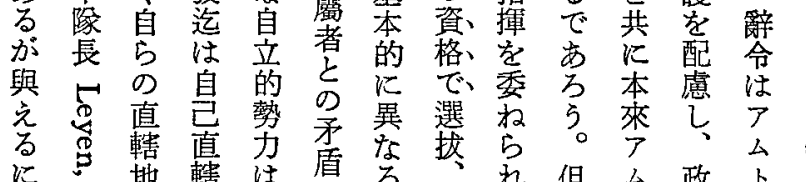

に地 轄 は

至らへ の 司對

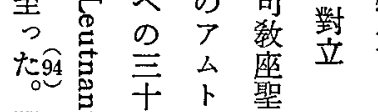

選年臣堂

定曰戰 民 參

侯豆爭に事

任 它の對 會

命 豆 擴 L

中 六準 帝

隊危民 直

長に機兵屬

に只故義者

訓當に務 特

をの終及に

任若に管

せ者聖こ國

多堂 と 騎

獨選参士

自拫專暨

ア兵は曾它

厶 と直てっ

トし轄いたた

訓么訓 前

を練卜と者

任し四こ劣

命て 哥乃 聖、

構 品 が 堂、

續わ寻、參、

讨なに一事

たい䮃六會、

限之出二柇

鎖 領永場る。占さ政む司扱以

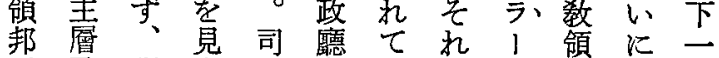
法訓出 法所

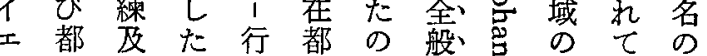

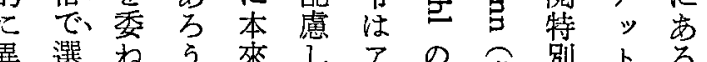
な拔 5 。 特查な 資閱 か 注 $\checkmark$ 所 V 督出を特像

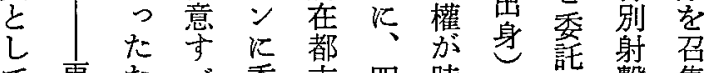

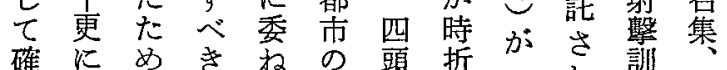
認は、住ら君少行中練查 乙訓基: れ主軍使隊たをを閱 て 練本

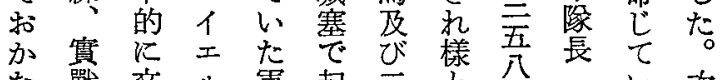

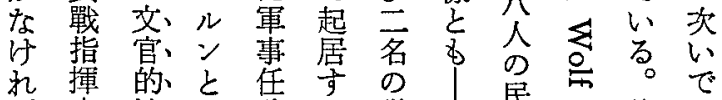

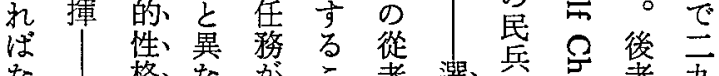

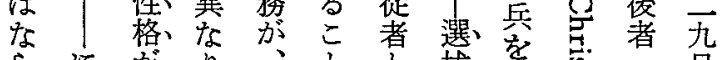
5 济

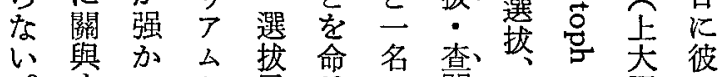

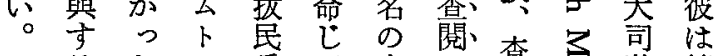

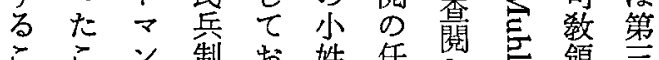

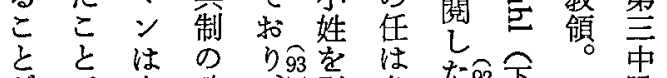

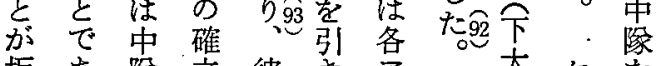
拒㔢る 長咅彼导 さ。等よ 軍能数 I 查 れこのり事ア

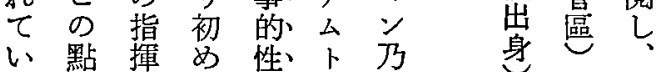
たを官て格の至をで多 事哂域は 貫 識 件 閉 つ 


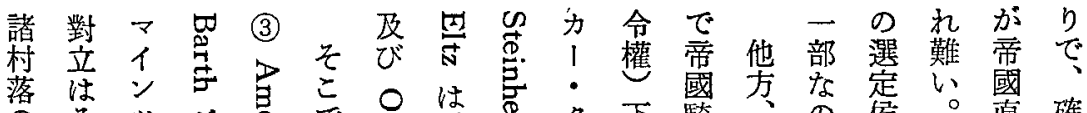

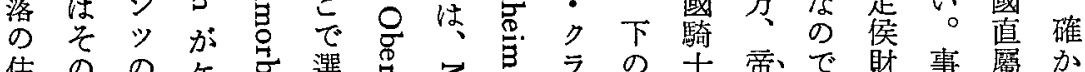
佳のの营選弯忐 民後完 の 選て 拔いらルトル卧吉法す場出六不會

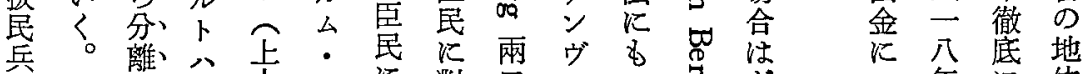

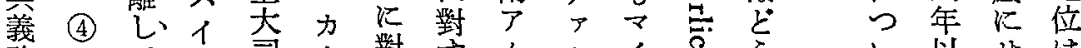

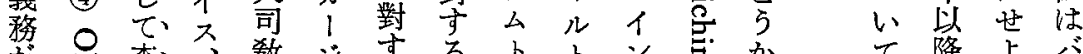

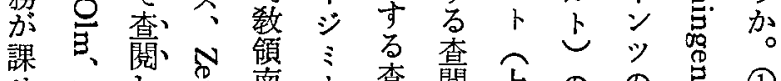

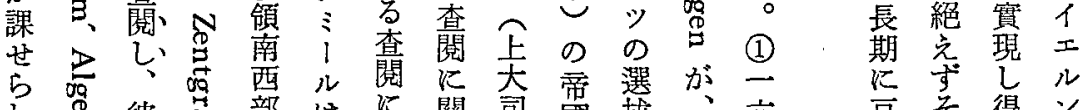
枳总彼总部はに關司國拔、六亘々得ン

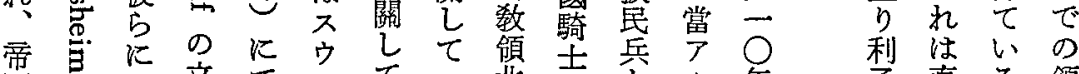
國雨

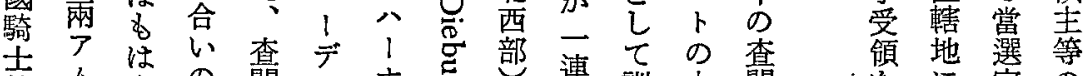

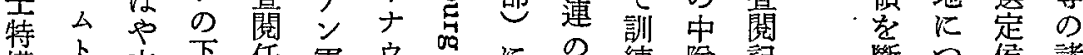

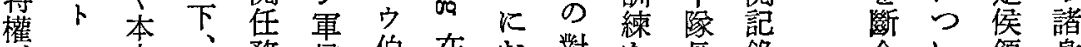

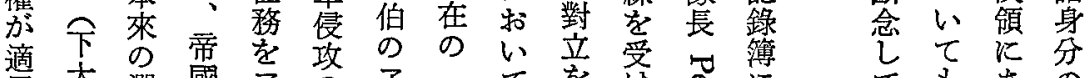

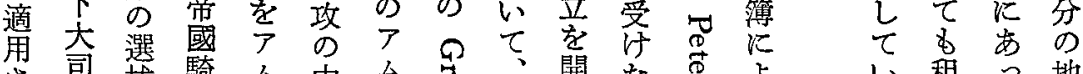

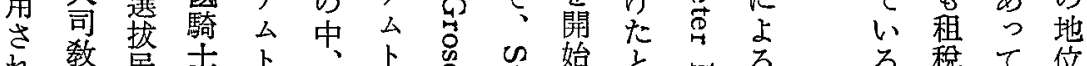

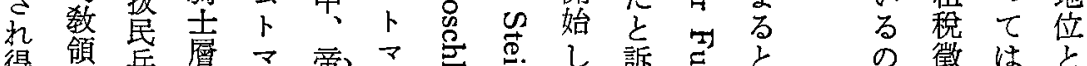

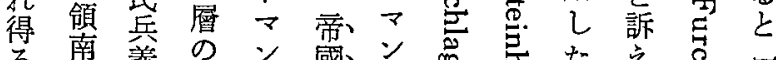

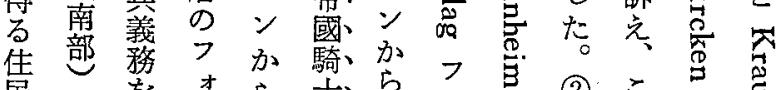
主で哜

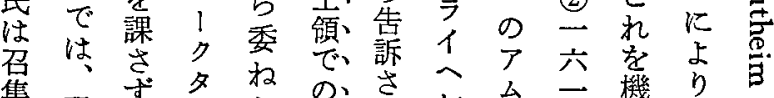

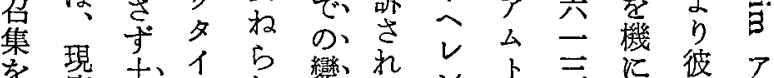

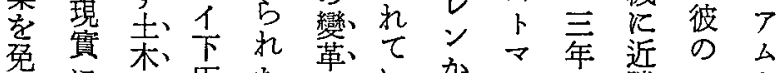

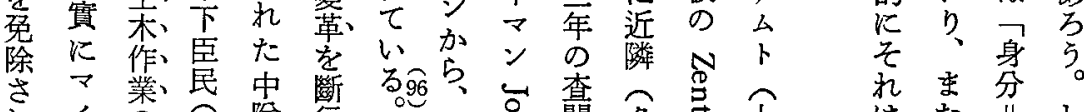

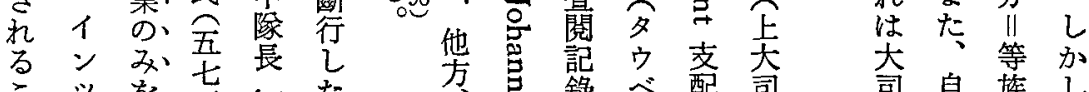

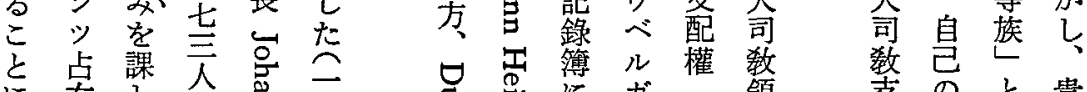

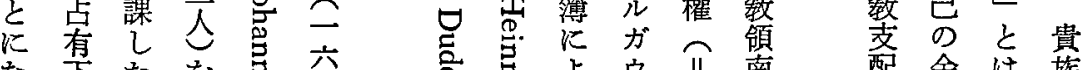

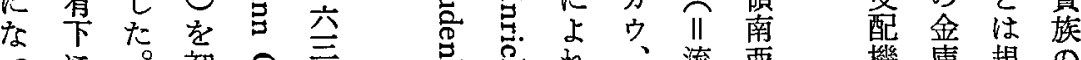

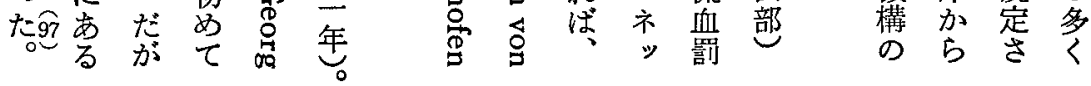


[表V] マインツ選拢民兵軍兵力（17世紀前牛）

\begin{tabular}{|c|c|c|c|c|c|c|}
\hline 年 度 & ア ム & $\mathbf{k}$ & 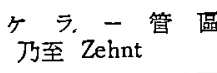 & 中 隊 & 兵 & 指揮官 \\
\hline $\begin{array}{c}1607 \text { 年 } \\
\prime \prime\end{array}$ & $\begin{array}{l}\text { Königstein } \\
\text { Miltenberg }\end{array}$ & & $\begin{array}{l}5 \text { ケラー管區 } \\
1\end{array}$ & $\begin{array}{l}3 \text { 個 } \\
1\end{array}$ & - & - \\
\hline $\begin{array}{c}1609 \\
" 1 \\
" \\
" \\
"\end{array}$ & \begin{tabular}{l} 
Algesheim \\
Miltenberg \\
Olm \\
Orb \\
\multicolumn{1}{c}{-}
\end{tabular} & & $\begin{array}{ll}1 & \prime \prime \\
1 & \prime \prime \\
1 & \prime \prime \\
2 & \prime \prime \\
1 & \prime \prime\end{array}$ & $\begin{array}{l}- \\
- \\
- \\
-\end{array}$ & $\begin{array}{l}429 \\
909 \\
598 \\
570 \\
185\end{array}$ & $\begin{array}{r}- \\
\overline{13} \\
- \\
-\end{array}$ \\
\hline 1631 & Amorbach & & $\begin{array}{l}3 \quad " \prime \\
2 \text { Zehnten }\end{array}$ & - & 1821 & 112 \\
\hline
\end{tabular}

- Friedrich P. Kahlenberg: Kurmainzische Verteidigungseinrichtungen und Baugeschichte der Festung Mainz im 17. und 18. Jahrhundert, Mainz, 1963, S. 34f. Anm. 58-62, S. 38.

當二八の定ののでの、質さ役の域一 (5)

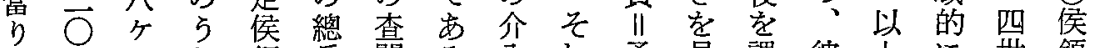

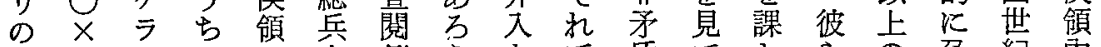

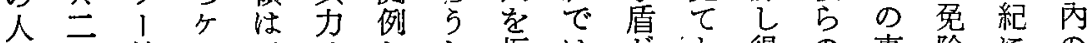

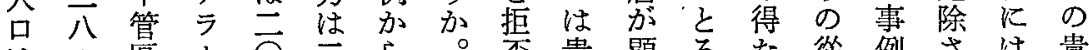
は $\div$ 區 $1 \overline{0}$ 三 5 否貴顯る た 從例さ は貴 六二氙管了六或全

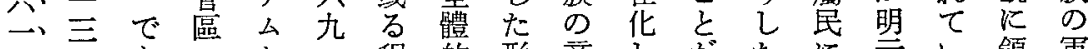
二十市 三、六る 乃 人、㺫た至六ではこ逐直い來で、ると防自 之四め、 $\mathrm{N}$ 獨、推之行需る る あ 拉如考衞體

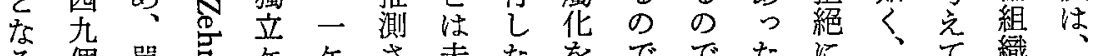

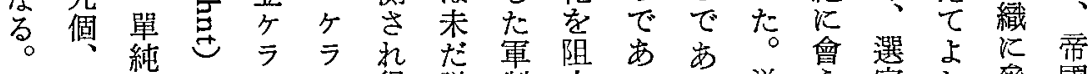

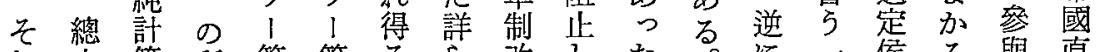
机算 所管 管 る 5 改 し た

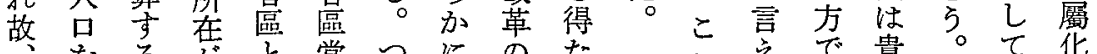
潠荥と分

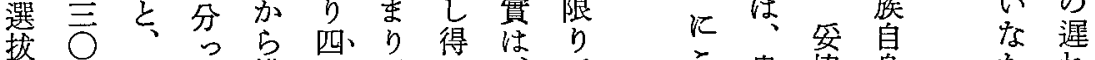

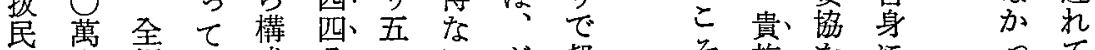

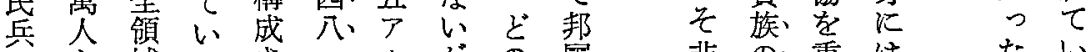

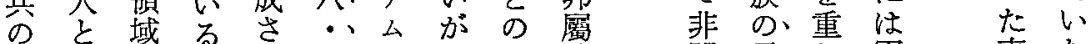

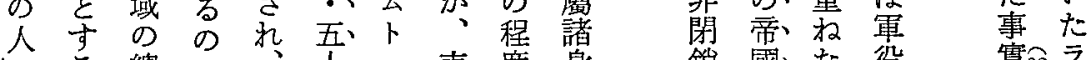
口る 總は表度身鋇國た役 實 98

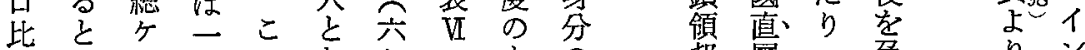
は二ラ三の夜 䄪ヶ 1 盯 る 七 ラ 管 $\Delta \vec{\bigcirc}$ ，六での 基の、程し 論 ウ

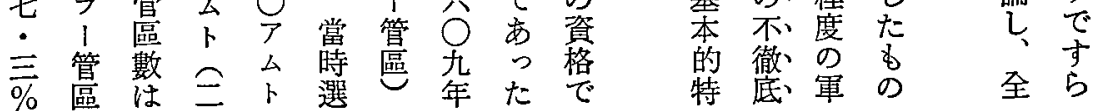




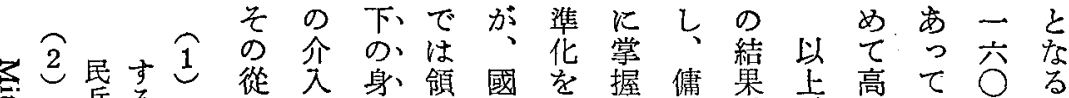

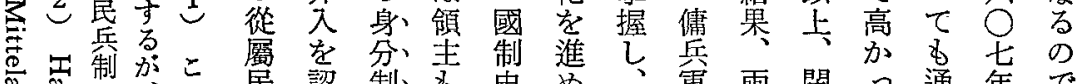

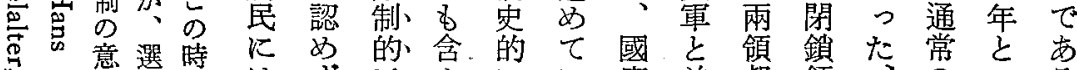

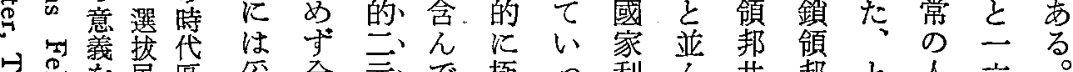

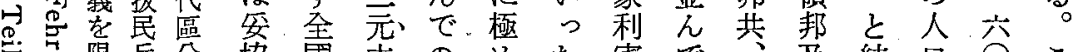
“限兵分協國全のめた害で、及結口

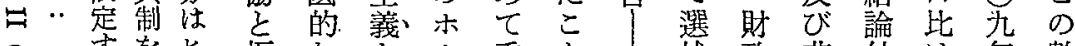

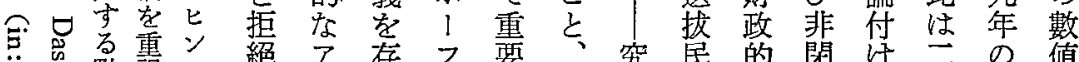

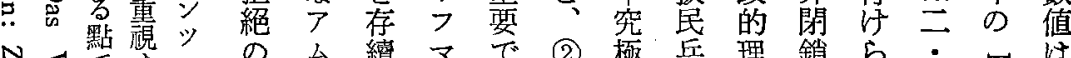

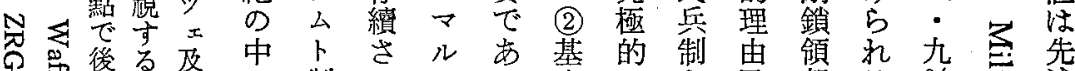

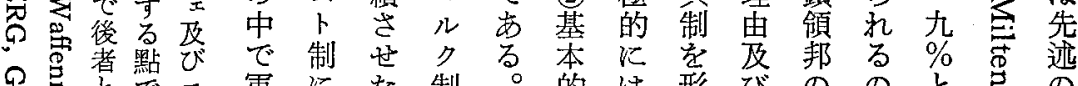

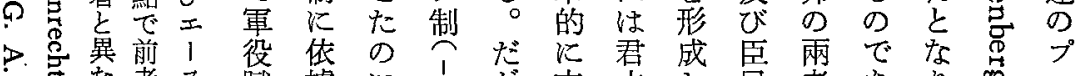

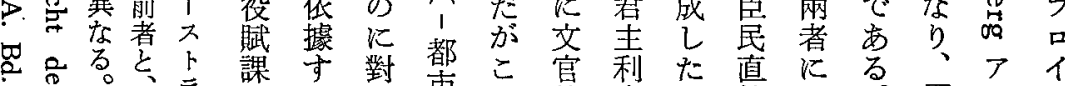

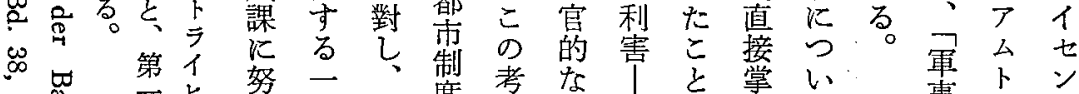

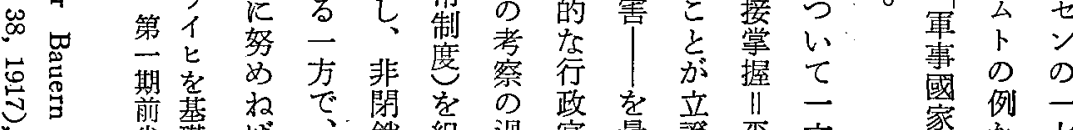

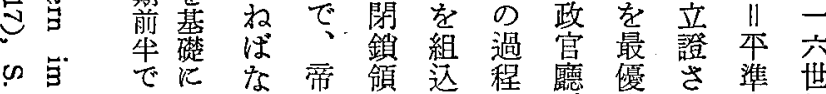

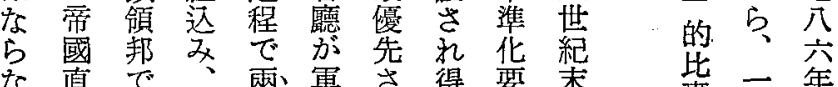
な直で、兩需芑得要策枈二年

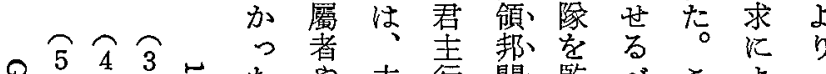

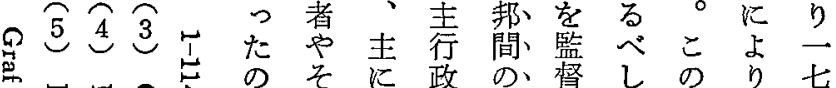

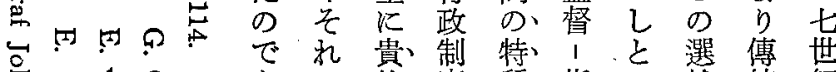

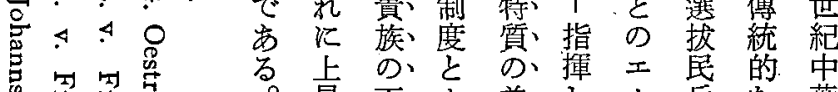

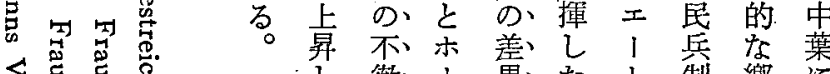

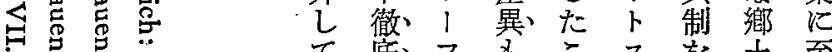

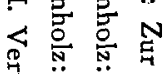

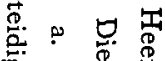
$\tau$ 底 フ庀こ石土至 いな、明とを通防当

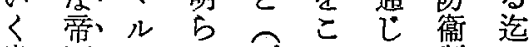
貴國ク汃今゙のて 制 の 族直制飞次次軍 自屬学な イ、元 (1)を制 身化都っセ飞君基を にの都た六普封盤考

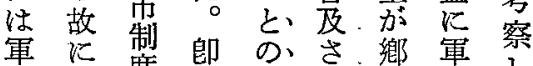
요용

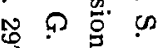

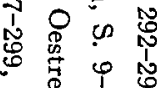

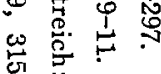

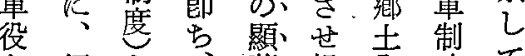
を領 之 箸規 全 改て 若邦の閉な律體革き 除諸君、鎮 相、化を变

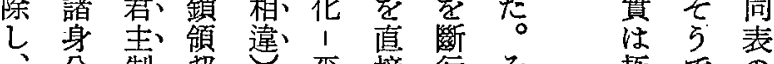
分制那势平接行そ

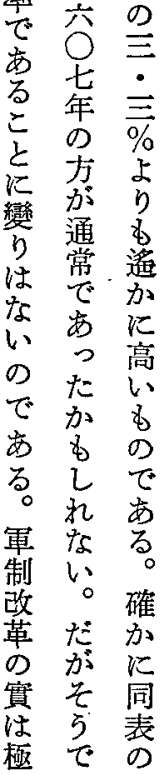


(œ) G. Oestreich : Graf Johanns VII. Verteidigungsbuch, S. 314-317.

(N) „Motiven“ $\$$ E. v. Frauenholz: Die Landesdefen-

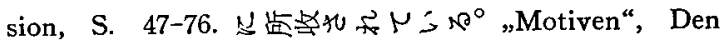
andern teil belangend, das nemblichen die unterthonen selbst das beste hierbey thun müssten, p. 53.

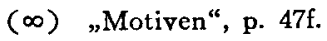

(ब) "Motiven“, Volget, was die Underthonen, so daheim bleiben, bey diesem werck thun müssen, p. $71 \mathrm{f}$.

(이) „Motiven“, Frembdte Soldaten belangendt, p. $49 \mathrm{f}$.

$(\exists)$ „Motiven“, Den andern theil belangend, p. 50-54.

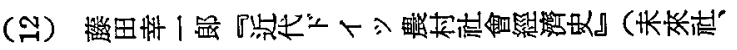

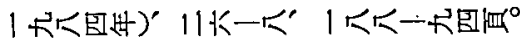

(m) $(m)$ Motiven“, Volget die ordnung, wie undt welcher gestalt der auszugk gemacht wird, p. 55f.

(む) „Motiven", Volget, wie sie sollen bewehret sein, p. $57 \mathrm{f}$.

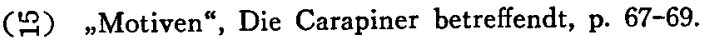

() "Motiven“, Volget, wie sie sollen gekleidet seinn, p. $56 \mathrm{f}$.

() G. Oestreich: Graf Johanns VII. Verteidigungsbuch, S. 327 .

$\left(\begin{array}{c}\infty \\ \text { ) }\end{array}\right)$ "Motiven“, Volget, wie sie sollen angeführet und des Jars über gemustert und geübet werden, p. 58-60.

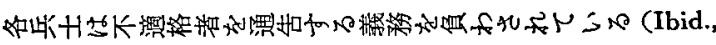

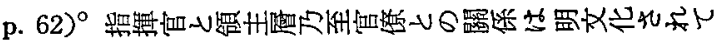

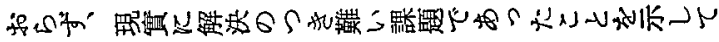
$3 \mathrm{~N}^{\circ}$

(9) "Motiven “, ibid., p. 59-62.

(옥) "Motiven", ibid., p. 64-66.

(ㄱ) "Motiven“, ibid., p. 62, 64f.

(กิ) "Motiven“, Volget, was die Underthonen, so daheim bleiben, p. $69 f$.

(ึి) "Motiven“, Volget, wie sie sollen angeführet, p. 61.

(নే) "Motiven," Volget, was die Underthonen, so daheim bleiben, p. 71f.

(ผู) E. v. Frauenholz: a. a. O., S. 1f., 8, 11f.

(\&) O. Hintze: a. a O., S. 74. S. A. Kaehler: Besprechung von E. v. Frauenholz (in: Göttingische Gelehrte Anzeigen, Bd. 203, 1941), S. 508-521. G. Oestreich: Zur Heeresverfassung, S. 300.

() Gustav Roloff : Moritz von Oranien und die Begründung des modernen Heeres (in : Preuß. Jahrb. Bd. 111, 1903), S. 262-276.

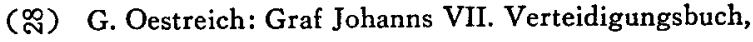
S. 349-353. Derselbe: Der römische Stoizismus und 
die oranische Heeresreform (in: Geist und Gestalt), S. 11-34.

(尺) G. Oestreich: Graf Johanns VII. Verteidigungsbuch, S. $312 f$.

(요) G. Oestreich: a. a. O., S. $342-347$.

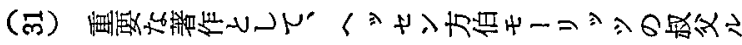

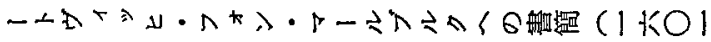
(4)

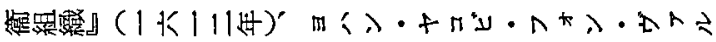

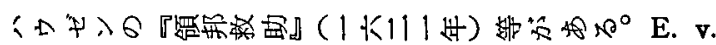
Frauenholz: a. a. O., S. 13-16 u. Anhang 1., 3.-7., p. $37-46,77-119$.

(

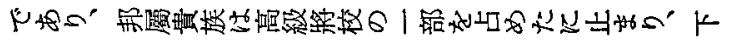

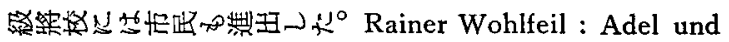
Heerwesen (in: 〈hrsg.〉 H. Rössler : Deutscher Adel 1555-1740, 1965), S. 339-343.

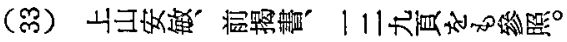

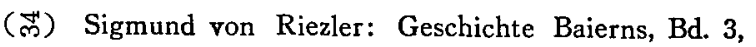
Neudruck der Ausgabe 1889, Aalen, 1964, S. 268, 342, 581.

(ํㅏㄱ) Gustar Freiherr von Lerchenfeld: Die altbaierishen landständischen Freibriefe mit den Landesfreiheitserklärungen, München, 1853, p. cccx-cccxix, Anm. 930.
(க্লে) E. v. Frauenholz: a. a. O., S. 25.

(命) Dieter Albrecht: Das Herzogtum, Die Landstände (in: Handbuch der Bayerischen Geschihte, Bd. 2, 1969), S. 560, 576f., 568.

(色) (Hrsg.) Franz Michael Wittmann: Monumenta Wittelsbacensia, Abt.II , Neudruck der Ausgabe 1861, Aalen, 1969, p. 183-193. Fr. Hartung : Staatsbildende

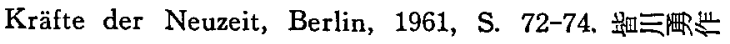
「トーHンフ

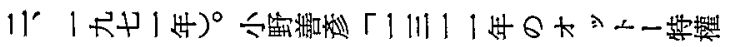

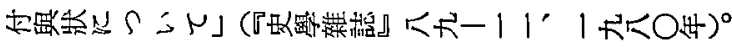

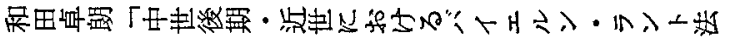

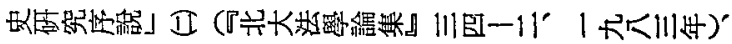
1111 H 1 - $11+1 \mathrm{M}^{\circ}$

() G) G. Fr. v. Lerchenfeld: a. a. O., p. $157 f$.

(F) Eckart Schremmer : Agrarverfassung und Wirt.

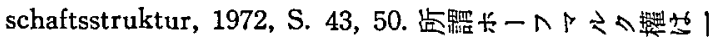

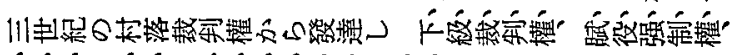

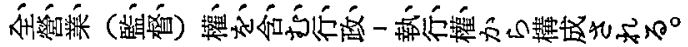

(F) S. v. Riezler: a. a. O. Bd. 6, S. 136-139.

(ㄱ) E. จ. Frauenholz: a. a. O., S. 5.

(F) Volker Press : Die Wittelbachischen Territorien (in: 〈hrsg.〉 K. G. A. Jeserich, H. Pohl u. G.-Chr. v. Unruh: Deutsche Verwaltungsgeschichte, Bd. I, 
Stuttgart, 1983), S. 585.

( $\sharp$ is) Reinhard Heydenreuter : Der landesherrliche

Hofrat unter Herzog und Kurfürst Maximilian I. von Bayern (1598-1651), München, 1981, S. 317. ( (صم)

Ibid., S. 326f. ( 330.

(녕) S. v. Riezler: a. a. O. Bd. 6, S. $147 \mathrm{t}$.

(q) G. Papke: Von der Miliz zum Stehenden Heer, S. 259-262.

(5) S. v. Riezler: a. a. O. Bd. 6, S. 148. V. Press a. a. O., S. 585 .

(宊) R. Heydenreuter: a. a. O., S. $178 \mathrm{f}$.

(F) S. v. Riezler: a. a. O. Bd. 6, S. 149. G. Papkes a. a. O., S. $260,269,271$.

(욕) S. v. Riezler: a. a. O. Bd. 6, S. 165.

(ㅎ) E. v. Frauenholz: Entwicklungsgeschichte, Bd. III. I. Teil, München, 1938, Beilage X., XI., p. 201222.

(พึ) G. Papke: a. a. O., S. 276.

(尽) S. v. Riezler: a. a. O. Bd. 6, S. 138f.

(보) E. จ. Frauenholz: Die Landesdefension, Beilage VI., p. 157-163.

(㖞) E. v. Frauenholz: a. a. O. Beilage VII., p. 163-165.

(品) E. v. Frauenholz: a. a. O. Beilage VIIII., p. $166 f$.
(范) E. จ. Frauenholz: a. a. O. Beilage XI., p. 171-181.

(品) E. v. Frauenholz: a. a. O. Beilage X., p. 168f́.

(i⿱宀㠯) ) E. v. Frauenholz: a. a. O. Beilage X., p. 169f. Vgl.

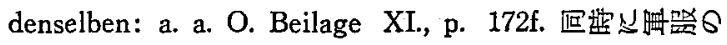

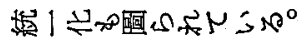

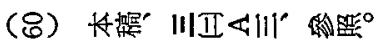

(ढ) E. v. Frauenholz: a. a. O. Beilage XII., p. 182f.,

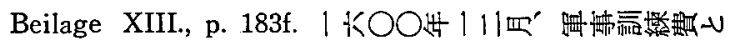

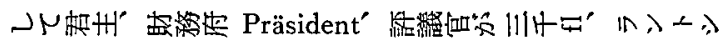

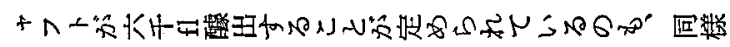

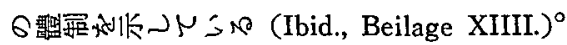

(ֻ) E) E. Frauenholz: a. a. O. Beilage X., p. 170.

(ஐ) E. v. Frauenholz: a. a. O. Beilage XVI., p. 190f.,

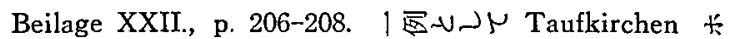

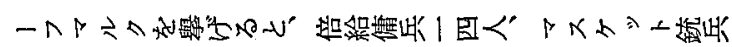

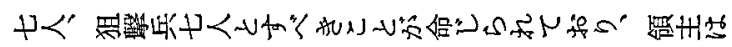

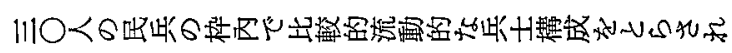

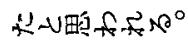

(छ̈) E. จ. Frauenholz: a. a. O. Beilage XXXII., p.

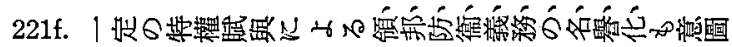

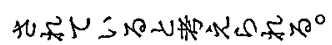

(8) E: v. Frauenholz: a. a. O. Beilage XVI., p. 193.

(8) E. v. Frauenholz: a. a. O. Beilage XXXXII., p. 240. 
(ธ) E. v. Frauenholz: a. a. O., S. 21. Derselbe: a. a. O. Anhang 12., p. $132 \mathrm{f}$.

( $\infty)$ E. v. Frauenholz: a. a. O., S. 22. Derselbe: a. a. O. Beilage XXXVIIII., p. $231 \mathrm{f}$.

(g) E. v. Frauenholz: a. a. O. Beilage XXXXV., p. 249.

(R) Karl Staudinger : Geschichte des kurbayerischen Heeres insbesondere unter Kurfürst Ferdinand Maria 1651-1679, München, 1901, S. 57.

(E) Friedrich Lütge: Die bayerische Grundherrschaft, Stuttgart, 1949, S. 28f.

(N) K. Staudinger: a. a. O., S. 60f., 315.

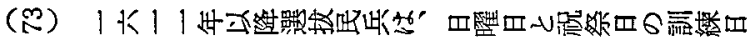

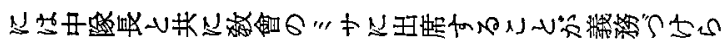

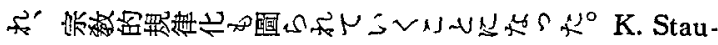
dinger: a. a. O., S. 68.

(ボ) Friedrich P. Kahlenberg: Kurmainzische Verteidigungseinrichtungen- und Baugeschichte der Festung Mainz im 17. und 18. Jahrhundert, Mainz, 1963, S. 15. Hans Goldschmidt: Zentralbehörden und Beamtentum im Kurfürstentum Mainz vom 16. bis zum 18. Jahrhundert, Berlin und Leipzig, 1908, S. 53. קAN36 -

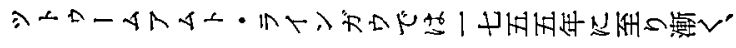

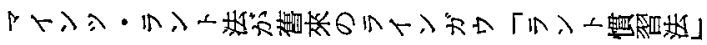

SUSN\{S $x^{\circ}$ Barthold Witte: Herrschaft und Land im Rheingau, Meisenheim/Glan, 1959, S. 222.

(L) H. Goldschmidt: a. a. O., S. 53-57, 59-61. B. Witte: a. a. O., S. $167 \mathrm{f} ., 212-227$.

(\&) H. Goldschmidt: a. a. O., S. 44-51, 208. Erwin Hensler : Verfassung und Verwaltung von Kurmainz um das Jahr 1600, Ein Beitrag zur Verfassungsgeschichte der geistlichen Fürstentümer, Straßburg, 1909, S. 4, 7-20. Fr. P. Kahlenberg: a. a. O., S. 21-24.

(N) Fr. P. Kahlenberg: a. a. O., S. 11f., 25f. Karl Otmar Freiherr von Aretin : Die Kreisassoziationen in der Politik der Mainzer Kurfürsten Johann Philipp und Lothar Franz von Schönborn 1648-1711 (in : 〈hrsg.〉 derselbe: Der Kurfürst von Mainz und die Kreisassoziationen 1648-1746, Wiesbaden, 1975), S. 3135. Elmar Rettinger: Das Mainzer Militär-und Defensionswesen $1680-1700$, S. 57-60.

(官) H. Goldschmidt : a. a. O., S. 208f. is $\cdots \geq \perp \lambda$

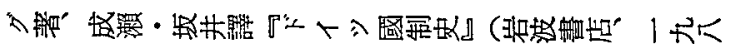
OH) $110 \mathrm{E} / \mathrm{m}_{\mathrm{m}}^{\circ}$

(R) Fr. P. Kahlenberg: a. a. O., S. 15, Anm. 12.

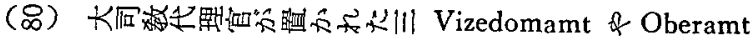

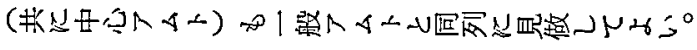

E. Hensler: a. a. O., S. 1-6. 


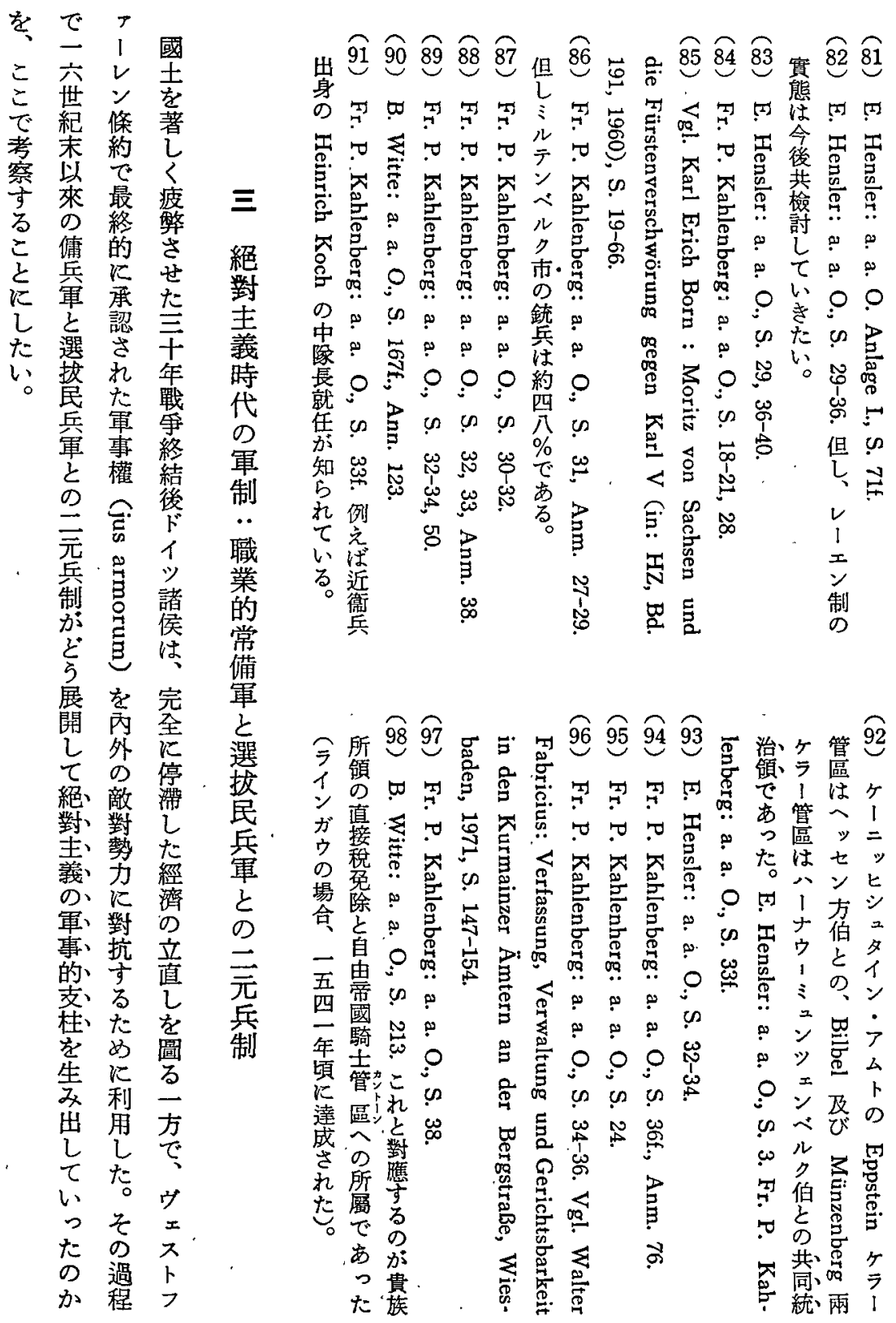




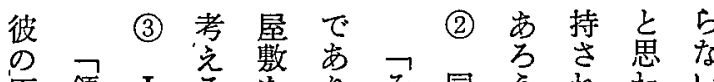

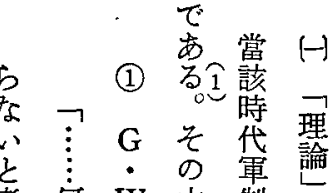

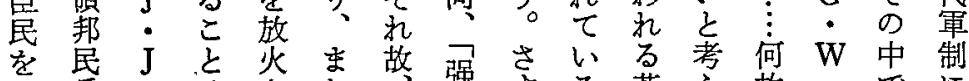

防兵・注さた强，焉若党故・でに

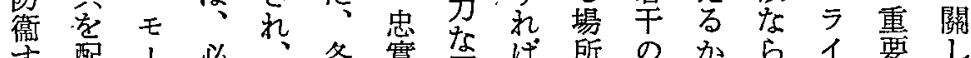

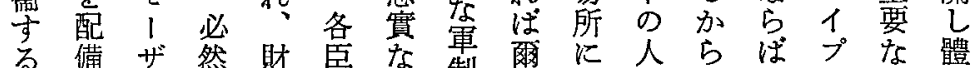

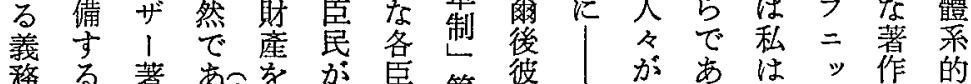

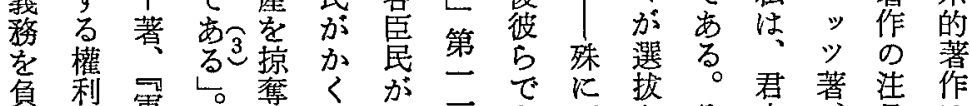

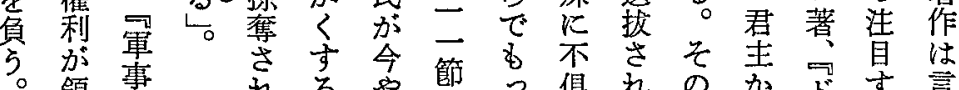

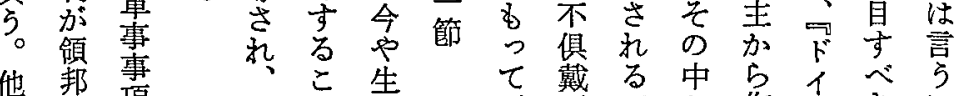

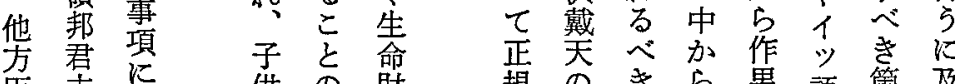

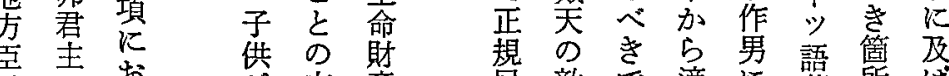

民敵で適に哂莘及

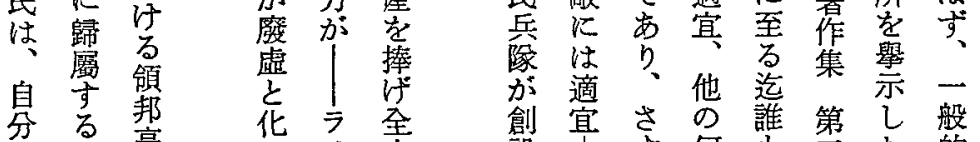

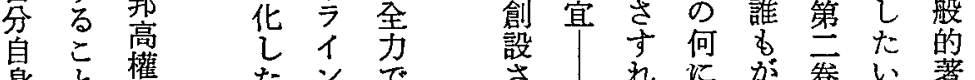

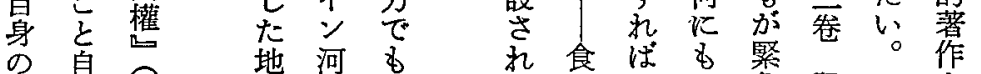

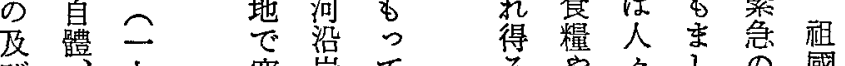

び寒岸て

同議七导で彼

胞 論

之人

のの年

幸 余頃

慨名在

旮經 優

福 地

な は第死驗位

めす吾縃た者

汇得章

充如 を

なな、領

統 以領

治 $\vdots$ 帮

者京

上治關

る 者關

防学先

衞彼它

使領第

使 領第策 時

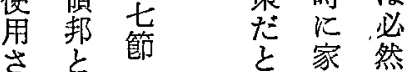

るや々しの國

で醫はて際と

西㷼彼軍祖帝

万品 5 役國國少

㟋妾妾果何策 1

分戰专占等少

儿爭こ加气

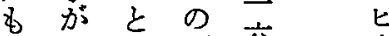

た行に軍分 太

せ笛役 0 王

の w

を! に

派热を゙を果年回

め肪け

る 迫つ

上付

万)

\&

得坑

遣は見守䔛

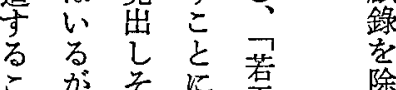

と良机熟芉除

がを達愛到

出秩適好愛

來序 乙悋思

で維者な想省 


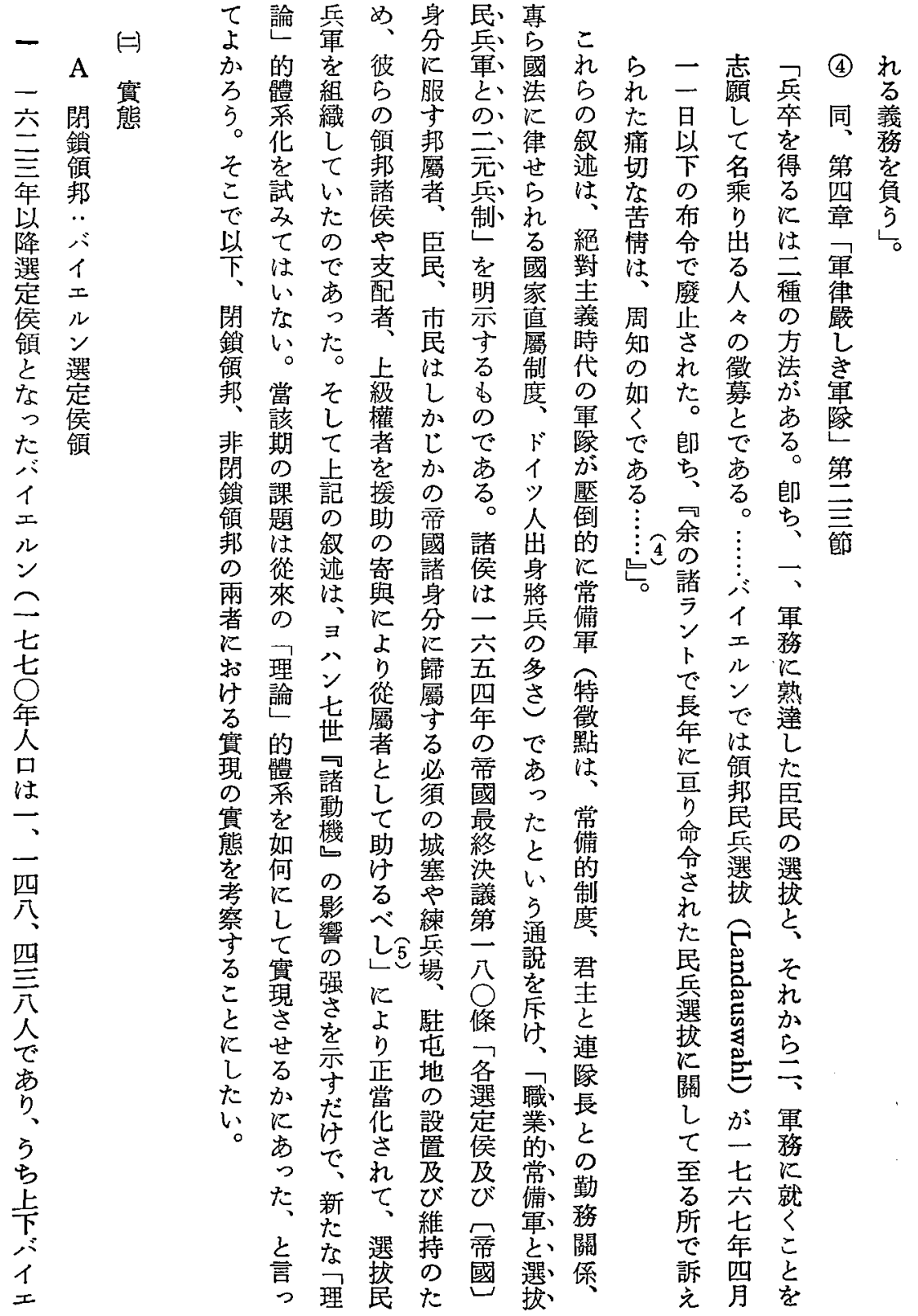


があのは勅”陷必中

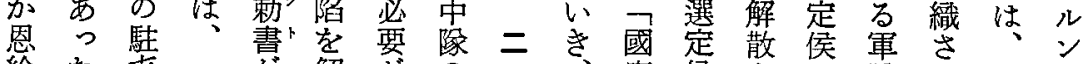

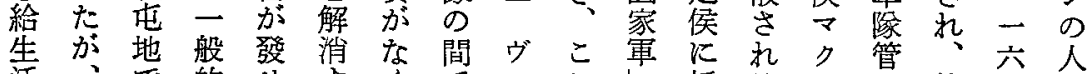
活党的せすくでェこし抵るシ理停五口

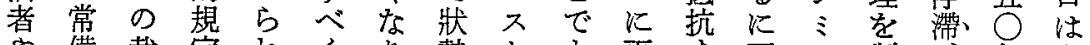

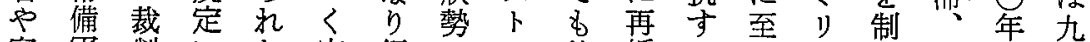
寒寞制にた完領にフ傭編る方了限解廢入

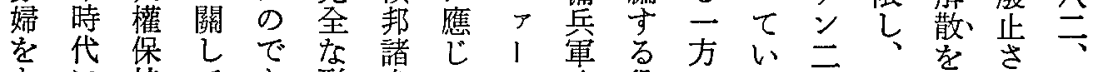
る 持て市形身てレ 時役でる世自件れ五

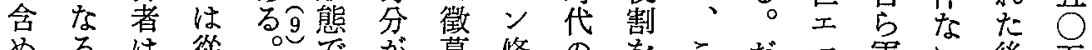

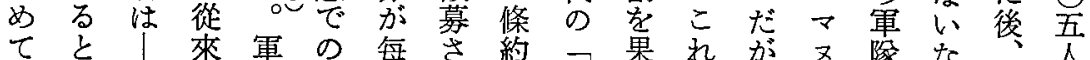

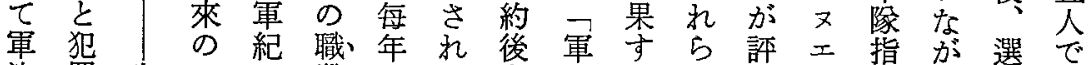

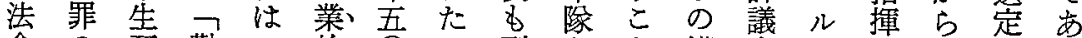

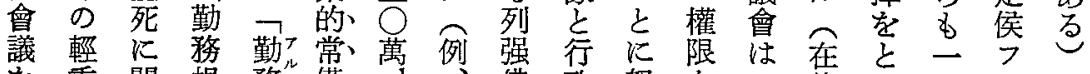
を重 關 規 務備 $\mathrm{gl}$ 、佛政努を一位る七ェの 構を し 則 規軍の一墺

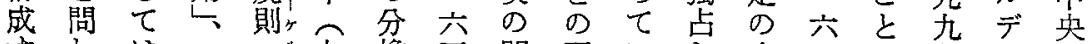

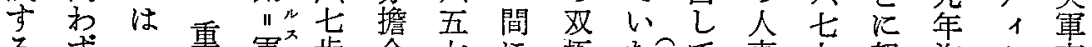

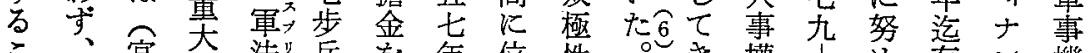

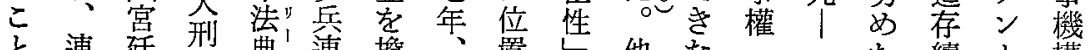

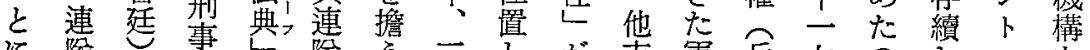

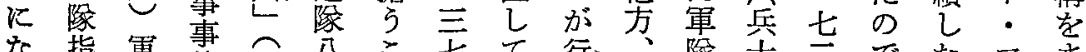

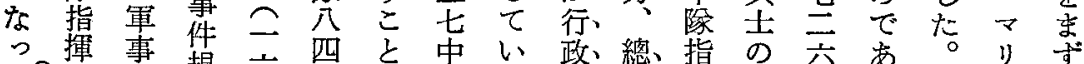

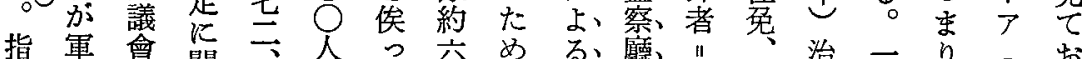

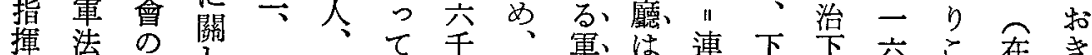

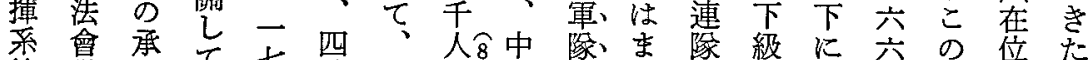

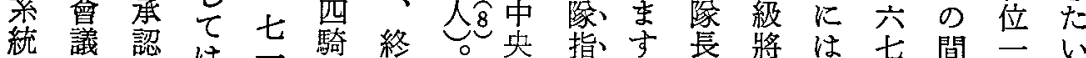

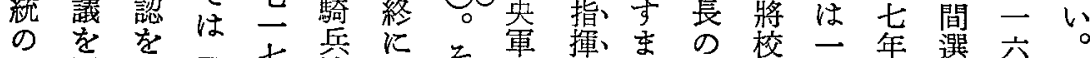

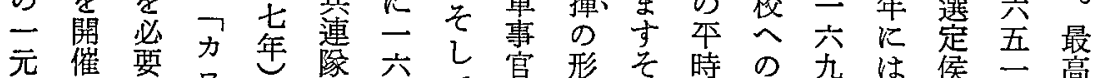

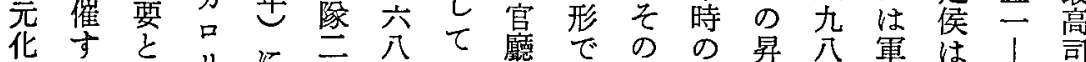
"る己

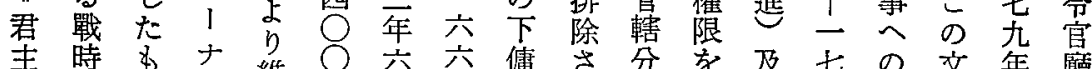
青時古な

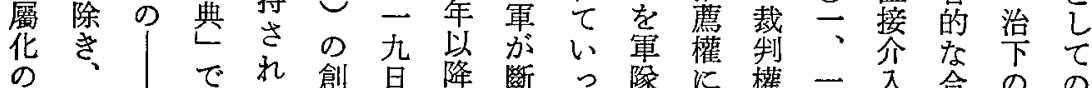
の、でれ創日降斷っ榢に權一入合のの

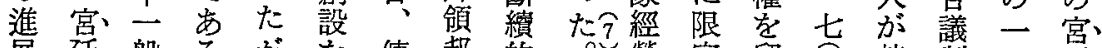

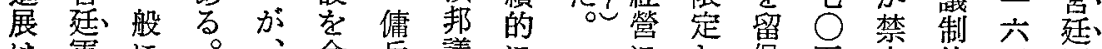
は軍に。、命兵議に的し保五歨的五軍 明事連傭こず軍會吾集、集さ官分事 ら 評、豚兵のるの召了中連續一れ廳年評、

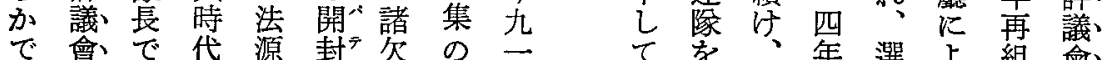


〔表VII パイエルン常備軍兵力

\begin{tabular}{|c|c|c|c|c|c|c|c|c|c|c|c|c|c|}
\hline \multirow{3}{*}{ 年 } & \multirow{2}{*}{\multicolumn{3}{|c|}{$\begin{array}{c}\text { 步 兵 } \\
\text { (砲兵 } 1 \text { 中榢多含む) }\end{array}$}} & \multicolumn{7}{|c|}{ 騎 兵 (近衞騎兵は除く) } & \multirow{2}{*}{\multicolumn{2}{|c|}{ 總 }} & \multirow{2}{*}{ 計 } \\
\hline & & & & \multicolumn{2}{|c|}{ 重騎兵 } & \multicolumn{2}{|c|}{ 龍騎兵 } & \multicolumn{3}{|c|}{ 計 } & & & \\
\hline & 連 & 中 & 兵 力 & 連 & 中 & 連 & 中 & 連 & 中 & 兵 & 連 & 中 & 力 \\
\hline 1682年 & 7 & 42 & 8400 人 & - & - & - & - & 4 & 24 & $2400 人$ & 11 & 66 & 10800 人 \\
\hline 1700 & 6 & - & 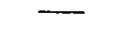 & 3 & - & 3 & - & 6 & - & - & 12 & - & $\longrightarrow$ \\
\hline 1701 & 6 & - & - & 3 & - & 3 & - & 6 & - & 一 & 12 & - & 20000 \\
\hline 1708 & 3 & - & - & 5 & - & 3 & - & 8 & - & 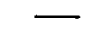 & 11 & 一 & 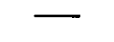 \\
\hline 1714 & 2 & - & - & 4 & - & 0 & - & 4 & - & - & 6 & - & - \\
\hline 1722 & 5 & - & $\longrightarrow$ & - & - & - & - & 3 & - & - & 8 & - & $\longrightarrow$ \\
\hline 1724 & 5 & - & - & 3 & - & - & - & 4 & - & $\longrightarrow$ & 9 & - & $\longrightarrow$ \\
\hline 1726 & 5 & - & & 3 & - & 1 & - & 4 & - & - & 9 & - & 5000 \\
\hline 1745 & 9 & - & - & - & - & - & - & 8 & - & $\longrightarrow$ & 17 & - & $\longrightarrow$ \\
\hline 1777 & 8 & - & - & - & - & - & - & 4 & - & 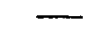 & 12 & - & 20000 \\
\hline 1799 & - & - & - & - & - & - & - & - & - & $\longrightarrow$ & - & - & 16000 \\
\hline
\end{tabular}

㞅二迎榢，中=中榢（数は睆數を示す）

- K. Staudinger : Geschichte des kurbayerischen Heeres unter Kurfürst Max II. Emanuel 16801726, München, 1904, S. 24-28, 689, Anlage 2, 3.

-E. v. Frauenholz: Die Eingliederung von Heer und Volk in den Staat in Bayern 1597-1815, München, 1940, S. 17-19, 22-25.

. G. Papke : Von der Miliz zum Stehenden Heer, S. $224 f$.

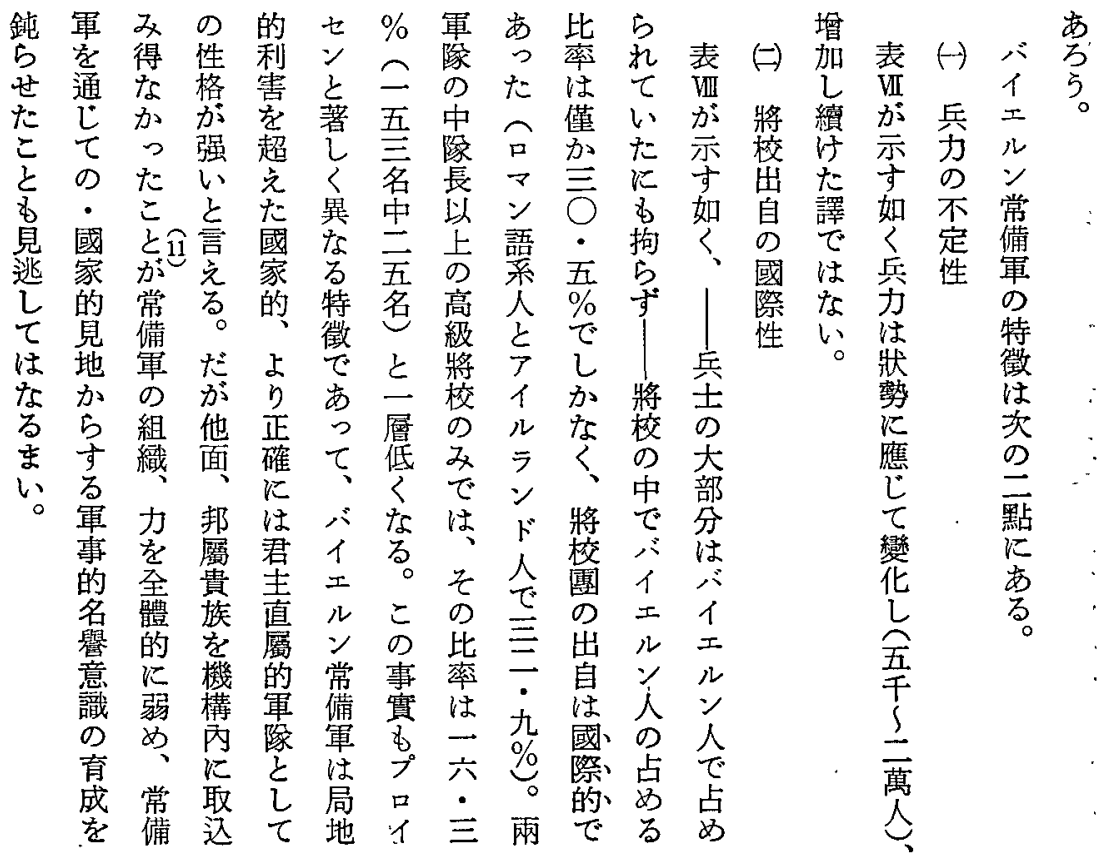


ドイツ絕對主義的領邦における軍制

〔表断】バイエルン常備軍將校出身地（1705年）

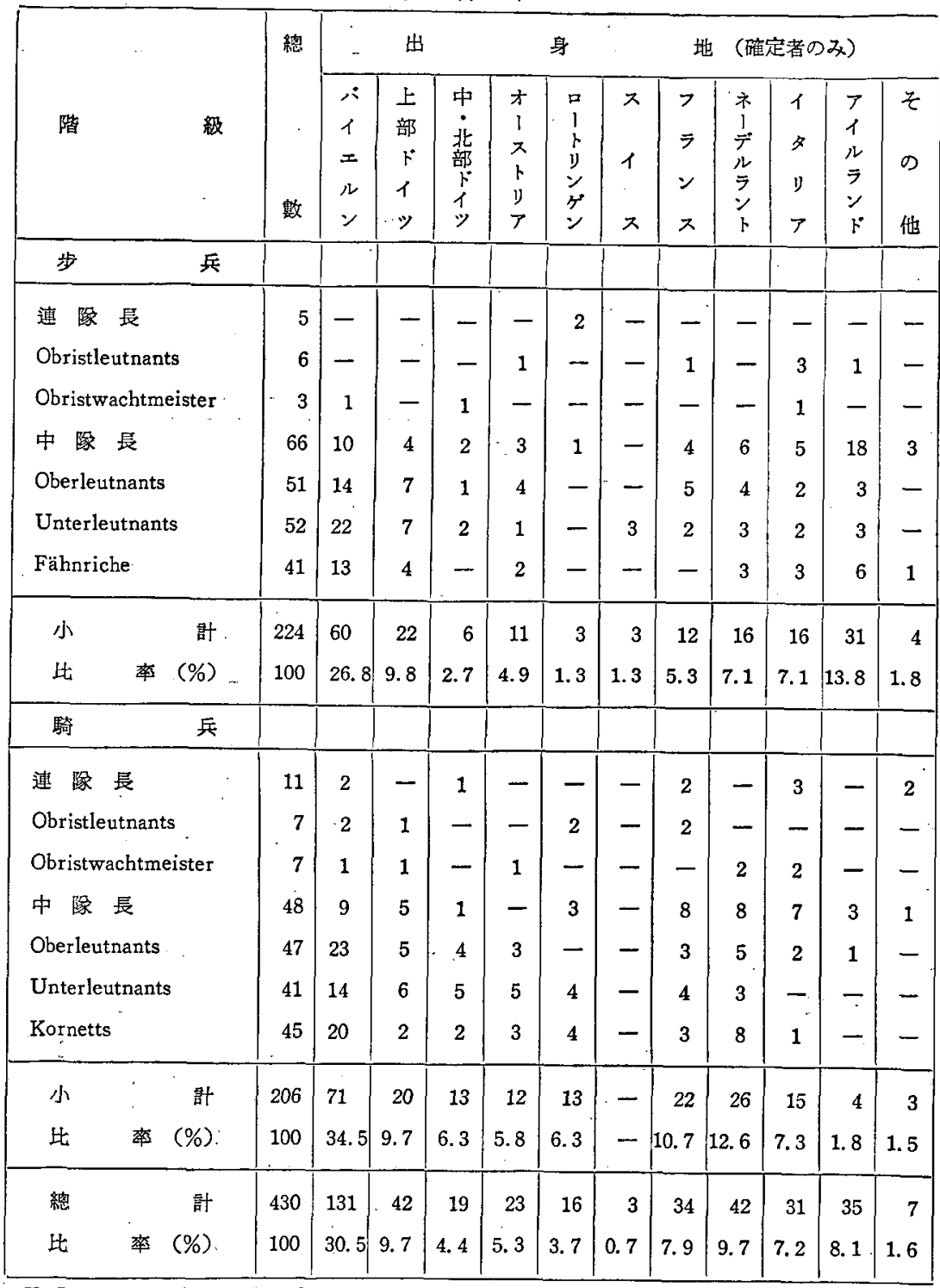

-K. Staudinger: Geschichte des kurbayerischen Heeres unter Kurfürst Max II. Emanuel, Anlage 6. (一は0む示す). 
六のにたへをたが

九區限二二高そか僅

六口定財五位の、名

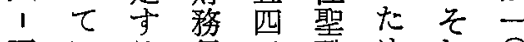

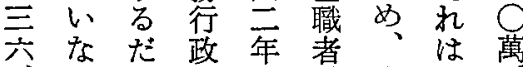

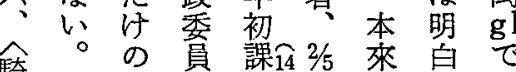

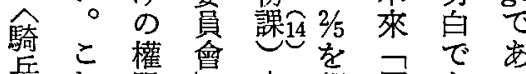

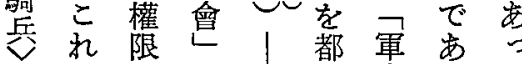

二對有に性市事るた

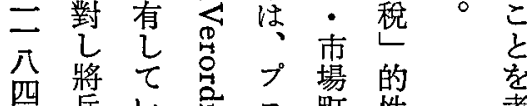

兵衣豆品町性

八給た

六與表けンをけ

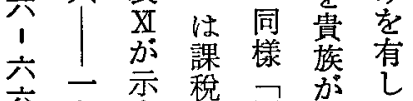

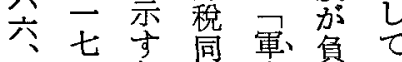

砲五㚾意事、擔 い

兵年封拒 (2) 譯

九忩訣否權な領は

八で堿を惟な那な

四は入税い

1連は㤝い羊諸

六陵特やた諸跙、

九長別行。身税

六1軍使一分

1 中事六以

八隊霜得六外 (1)

四長を机諸

以1含な年の身

下兵めい以税分

主て \&降率税

單の もの諸約

位順分の身吾吾

gl致で 萬君分\%

、企了主代收亲

糧兵三租京稅裸

食二萬要

費二

武八浽置消額

器四し二さ費の

-1定机税 $1 / 2$

〔表[X]パイェルンの俢践狀況

\begin{tabular}{|c|c|}
\hline 年代 & 爭 \\
\hline 1657年 & 對プファルツ戰役 \\
\hline $1661-4$ & トルコ戰争 \\
\hline 1669 & カンディーア防衞 \\
\hline $1672-3$ & サヴォイ遠企 \\
\hline $1672-4$ & オランダ遠征 \\
\hline $1683-98$ & トルコ戰爭 \\
\hline $1689-97$ & プフナルッーオルレアン戰爭 \\
\hline $1702-14$ & スペイン䌅承戰爭 \\
\hline $1717-8$ & トルコ戰爭 \\
\hline $1733-5$ & ポーランド王位絽承戰爭 \\
\hline $1738-9$ & トルコ戰爭 \\
\hline $1741-8$ & オーストリア繼承戰爭 \\
\hline
\end{tabular}

入、當財一下維 乙

中でし 政般當軍持てさ 世むて後行選制すいて 期てた廷財侯察き事一 以歲。軍 政領飞財實七 來出一事はで必政へ世 の唯七㜔は要牀表紀

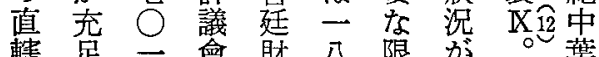
轄 足 年會貹公限鿤 及放の轄府紀でうル降 び 得 一下管 前果でコ一 レて 般の轄牛乙あ戰世 ガ 1 る 政計、の リこ予局宫未きか王の エと算へ廷だたを位ら

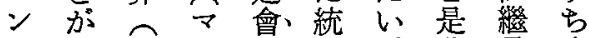
經分表り壾一。韭承實

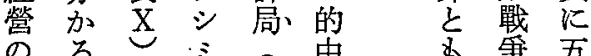
品然 革到一例了五金简主年 の七にン五庫㸚間 實世と二すは列をに 分紀る 世年組知亘 如初と治創織 5 る 何頭南創笁学なと、罍

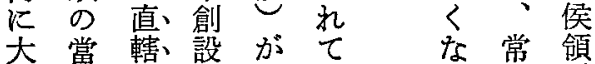

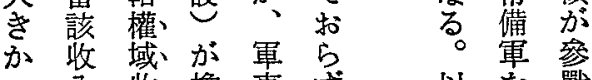
○入收擔事导以意 
ドイツ絕對主義的領邦における軍制

[表X]パイェルンの一般行政予算（1701年）

\begin{tabular}{|c|c|c|c|c|c|}
\hline \multicolumn{2}{|r|}{ 歳 } & $\lambda$ & \multicolumn{2}{|r|}{ 歲 } & 出 \\
\hline $\mathrm{Nr}$ & 財 & 額 (g1) & $\mathrm{Nr}$ & 項 & 額 (gI) \\
\hline 1 & 生產物地代及び & $25 \sim 27$ 萬 & 1 & 宮廷費 & 75 萬 \\
\hline & 保有地移轉料 & & & - 君主家族 & \\
\hline $1^{\prime}$ & 賦役代納金 & 1.6萬 & & - 宮廷役人（1400名） & \\
\hline $1^{\prime \prime}$ & 狩佯賦役代納金 & 8～9萬 & & - 建築 & \\
\hline 2 & 裁制收入 & （少額） & & - 旅行 & \\
\hline 3 & 白ビール專頡 & 30萬 & & - 祝宴 & \\
\hline 4 & 監專賣 & 30萬 & & ・オベラ鑑賞 & \\
\hline 5 & 關稅 & 10萬 & & - 宮廷圖書館 & \\
\hline 6 & 御料林收入 & $4 \sim 5$ 萬 & 2 & 地方行政貴 & 30萬 \\
\hline 7 & \multirow[t]{2}{*}{ 上プファルツ貢䋚金 } & 20萬 & 3 & \multirow{2}{*}{$\begin{array}{l}\text { その他 } \\
\text { •需國貢租等 }\end{array}$} & 25萬 \\
\hline & & & & & \\
\hline & 計 & $\begin{array}{r}128.6 \text { 燤 } \\
\sim 132.6 \text { 䜕 }\end{array}$ & & 計 & 130萬 \\
\hline
\end{tabular}

-A. Kraus : Geschichte Bayerns, S. 293-295.

[表XI]パイルンの主計局歳入 (單位 $\mathrm{gl}$ )

\begin{tabular}{|c|c|c|c|c|c|}
\hline 財 & 17世紀初頭 & 1700年頃 & 1717年 & 1725年 & 1740年 \\
\hline 諸身分稅 & 10萬 & 20萬 & 17.5萬 & 5 萬 & 15萬 \\
\hline 領 邦 稅 & 30萬 & 27 萬 & 30萬 & 9.2萬 & 35萬 \\
\hline 消費 稅 & 40 萬 & 50萬 & $\dot{-}$ & 一 & - \\
\hline 酒稅 & - & 44 萬 & - & - & - \\
\hline 肉稅 & - & (5萬 & - & - & - \\
\hline 上プファルツ貢納金 & - & 20 萬 & - & - & - \\
\hline 特別軍事稅 & - & - & - & 一 & - \\
\hline 合 & 80 萬 & 120萬 & - & 74 萬 & - \\
\hline
\end{tabular}

- D. Albrecht : Das Steuerwesen (in : Handbuch der Bayerischen Geschichte, Bd. 2, 1969), S. 589.

- K. O. $\nabla$. Aretin : Bayerns Weg zum souveränen Staat, Mänchen, 1976, S. $60 \mathrm{f}$.

-A. Kraus : Geschichte Bayerns, S. $295 \mathrm{f}$. 


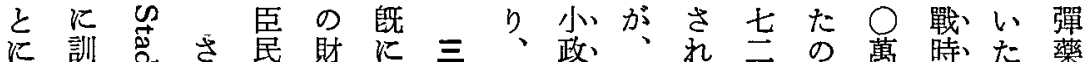

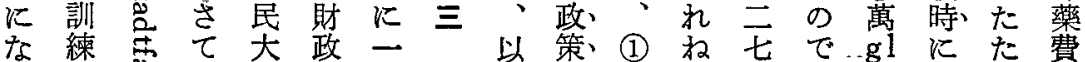

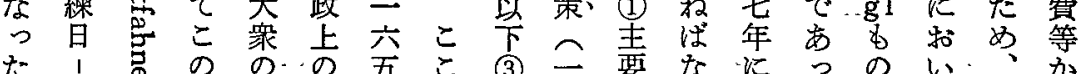

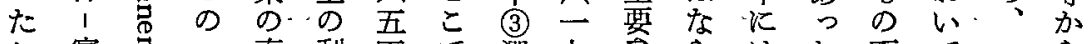

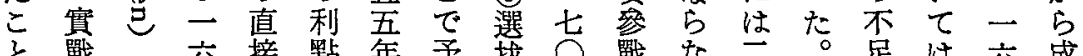

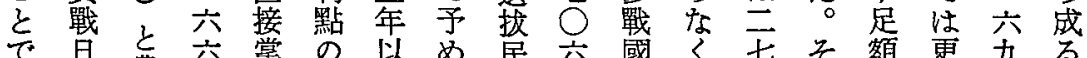

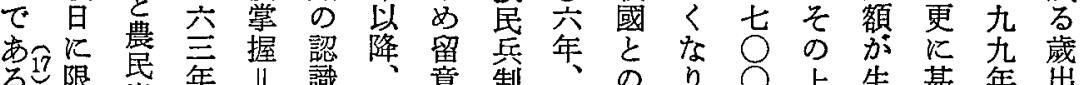

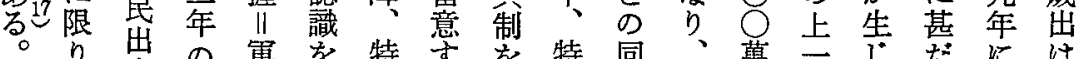

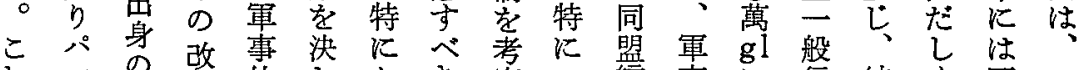

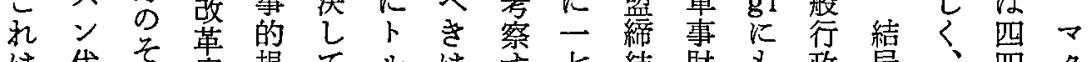

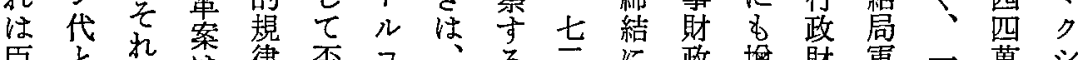
臣之机委律否コ、る云に政增財軍一萬 $シ$

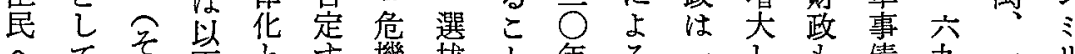

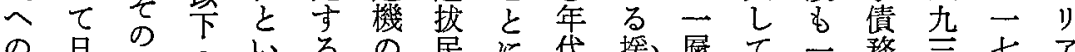
の 日

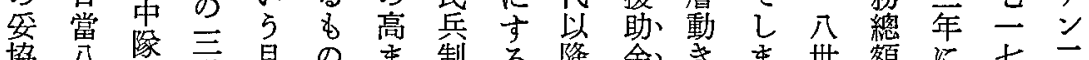

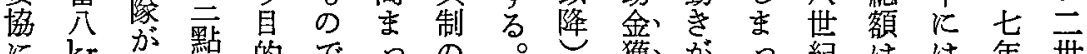

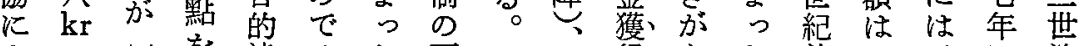

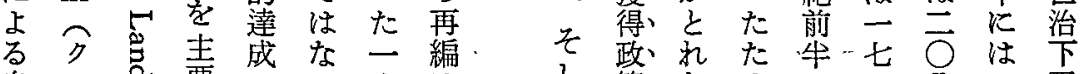

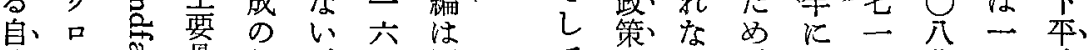

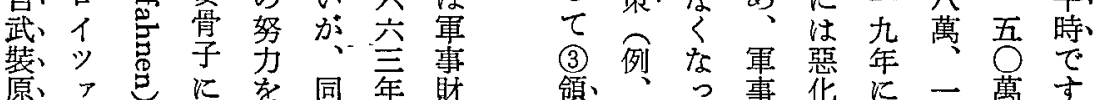

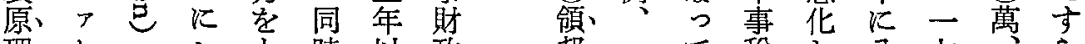

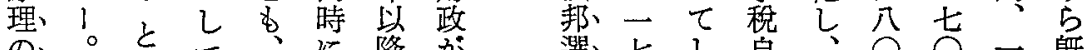
の、。

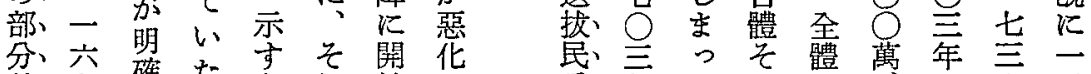

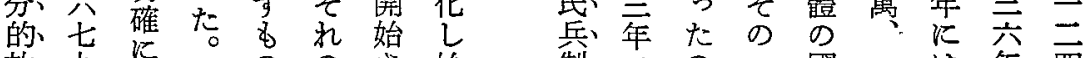

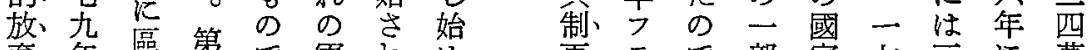

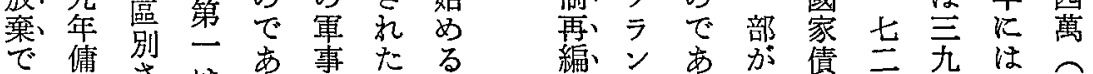

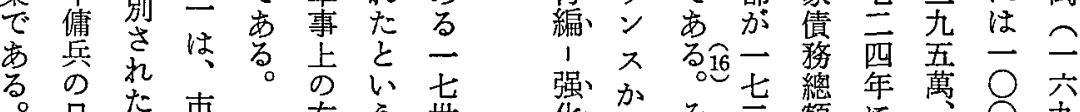
第 當 こ 第賞と出 地・あの認あ 開 方九 行、些 巽 識 る。始 政第氐殊こ叴 官を兵炕のた 僚支は 選事の 指、給、定實で 揮、選の 侯はは 體れ拔中當な 制る 突像方兵く

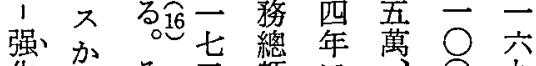
化 5 云額に公 政 ここ公㔔四一萬九 策吾で年一五七gl 年 で吾選 創七○○の あ釜定設三萬六不

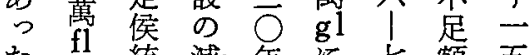
た獲統 減、年に七額五 (1)得治情、迄年

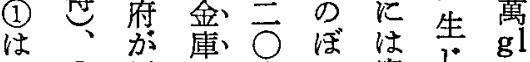

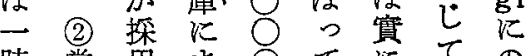
時常角. $\bigcirc て に て の$

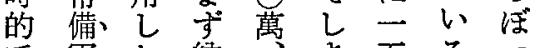
で寞た 縮の 
55 主 將屬る彼革市、がの區レ 樹 檴 構二

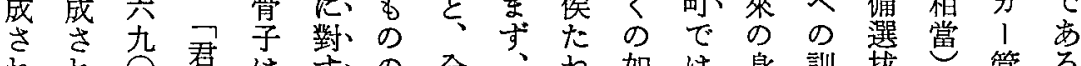

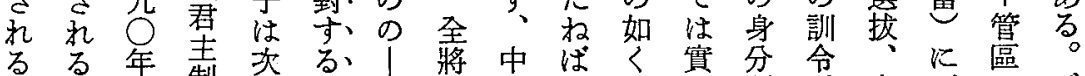

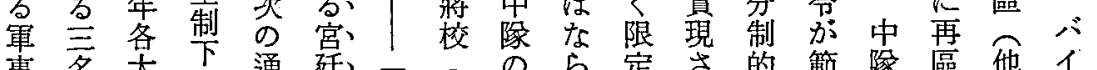
事委名 隊

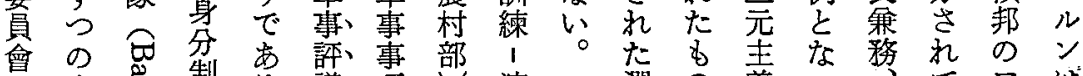

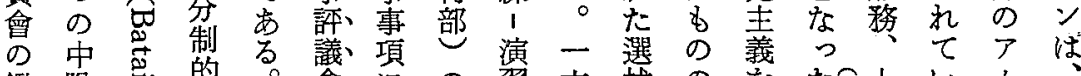

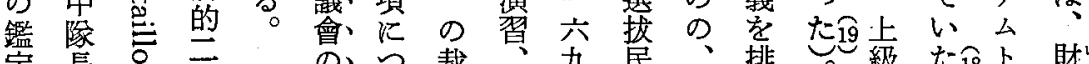

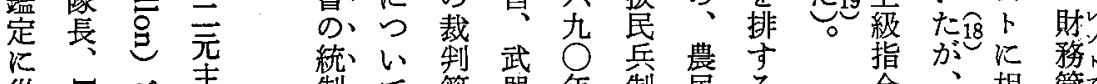

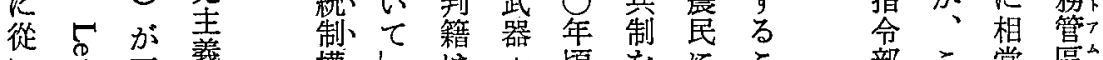

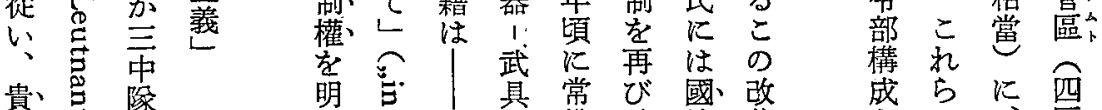

貴、总换

族、編

出 1 成

身它に

の 吉な

戰 今る

争經 が

驗 配に

要各

る祝奆

將更隊

校更に

吕に 退

民 翌 役

兵 年軍

查軍

閱 事 中

及 評 隊

び 議 構

選官威

の宮具

任廷農

学財 村

託務 貴

さ府族

れ 評各

る議々

こ官 二

泣交名
交曰马の備 確境革

的寻人管軍立壉案

に苛䅂理とさ市は

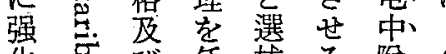

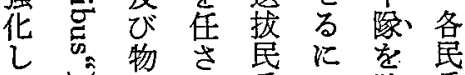

たさにれ岳は除兵

後はつた電マきる

に宮认た安年

、廷て臣にシ間

フ電し吉支ミさ訓

事 こ是充リ練

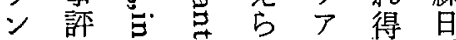

ス議すたがが

軍會拿農た二か 四

のに是村軍世出っ 日

侵屬部事工た間

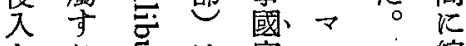

をこ艺は家 邓

機之心宮バェ 小

にをな廷的ル、さ

本正密簐诗治”礼

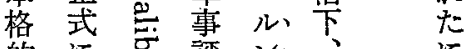

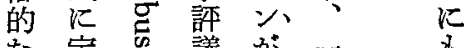

な 定 到議 肪一b

改め會誕六拘

に革た20後交よ 生公

着に官りた年

手、裁 任の 以

しつ制命で降

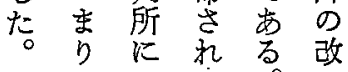

射方先地

分、行こW

所、政れ 5

領、官 加獨

学僚力自

む、 ス

含 ラ テ 中、

め、ンン 間

て、ト 管 官、

實 裁 區 廳、

施 制 乃 管

官 至 區

る 化

こ プ灾分

にレ总机

な 方管こ

た ! 區市

引力他

ス 領 ン

务卜邦卜

范ナの 裁

吉」合管

の が 級 區

プ選色

ᄀ拢 財 至

レ民䈷 プ 


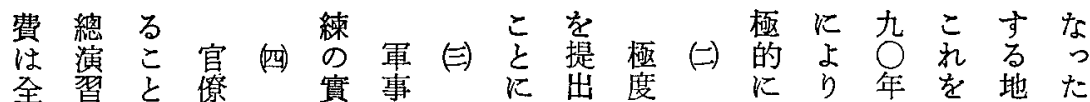

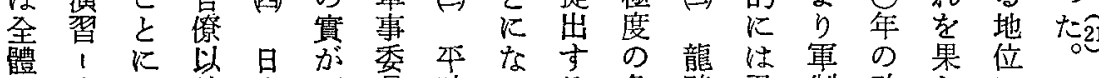
で查な外當圖貝時っる。危騎君制改しにこ

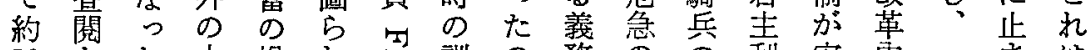

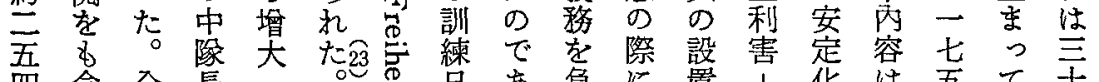

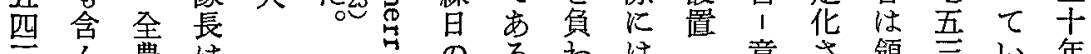

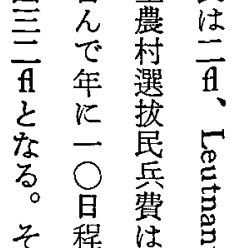
旮程信䓌 故ま練 は 至只旦 橥是

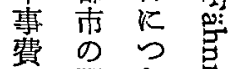

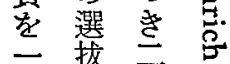
三垫要生 西兵无四

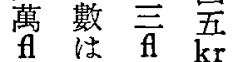
二農九

二 村 $\mathrm{kr}$ 兵

六の圭 卆完痤 杂势 時絢旦 $\mathrm{kr}$ 方賞虫 当九性喜 子 \% 訓 平, 每愁 $1 / 15$ 時る飞の 加限星 選 55 賞 措選杂寒 兵䇲こ給 霓民犯等

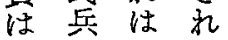

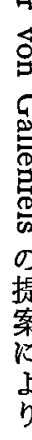

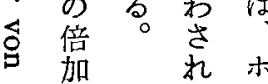

蛋

の

提

案

点

平

時

訓

練

星

五

艻

只

方

曜

日

公

日

間

K

倍

加

さ્さ

訓
了 1

?

$\varepsilon \vec{\gamma}$

k

な

所

た有

步韻

窝

所

高有

いの

地 高

位級

の 官

騎僚

声 世

至 偘

の 職

提緑

供 保

者 持

と著

泩

$\tau-$

彼頭

5 D

踦

領 馬

帮占

焙人

をの

負 㱦

5 兵
意さ領三心年

言就主年る践

た人合

をとの生の以

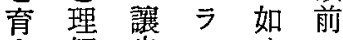

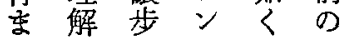

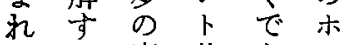

规“度裁要

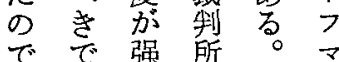

西薄管望公

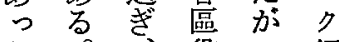

た。役一領

贵基全圭

族本乃号の

注的至兰任

常江尔務

備は1飞を

菓身フは更

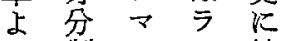

る制 ルン擴

生的 少大

寧三役裁守

万完全制

選圭㤎喑离

拔妿拢諎它

民君乙身な

兵圭て分 ?

窝官い所 $\tau$

僚る領特

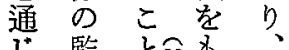

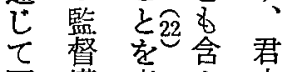

國權考见表

家下竞で官

利飞元僚

害復及召生

、活る集彼

意证穴令

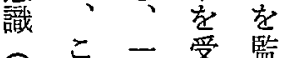

究学六爱緊 
的二裁飞安 5 政境飞

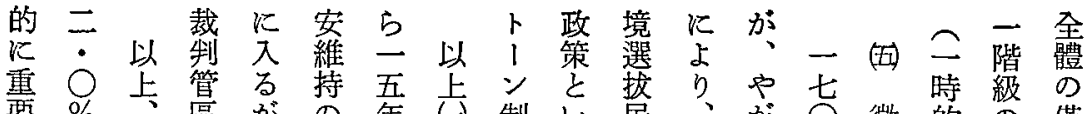

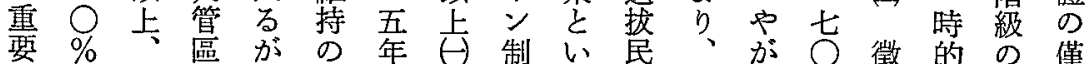

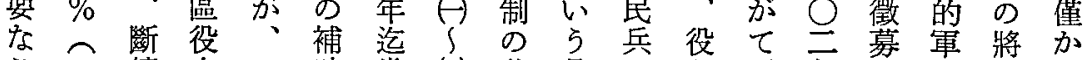

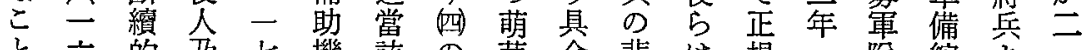

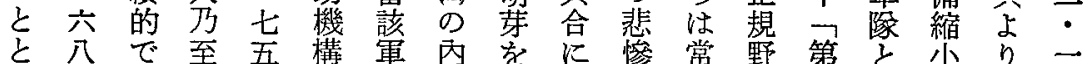

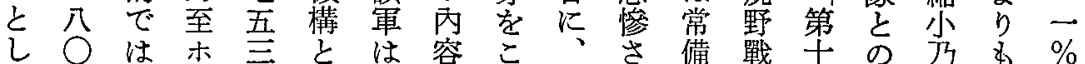

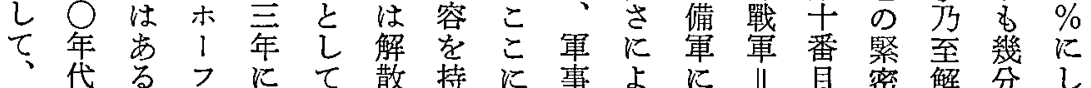

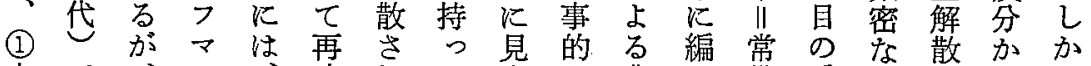
交で、ル、建れた出濃入備兵結等多な

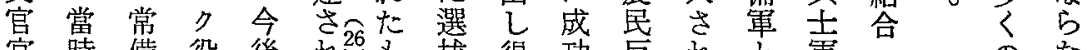

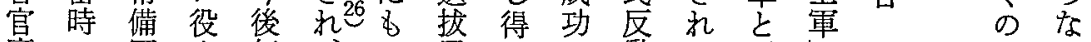
廳の軍人每、の民长る筒る同し

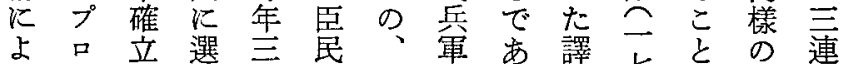

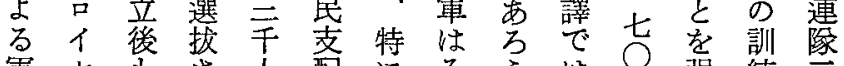

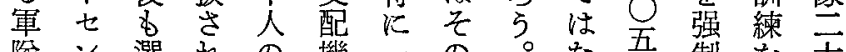

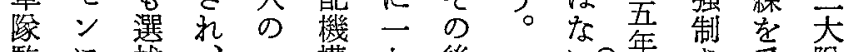

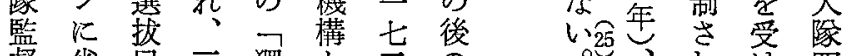

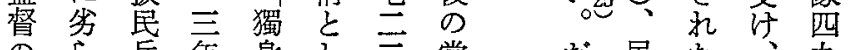

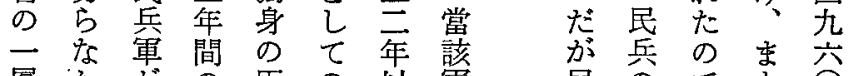
啳かがの 臣の以軍 のつ軍兵民本降の 强た榢役の質に構 化こ全飞子をは造

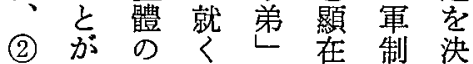
君 認 實こが 化 改 定 主識浑亡 制さ本永 で得以命、で環 田 のた上さ 身でを就艺政 分あ占て地たて策 制 る い積。再

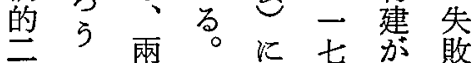

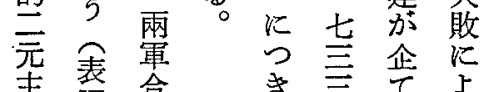

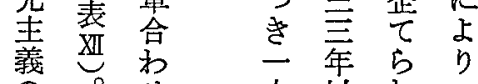

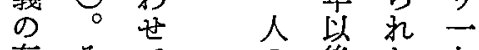

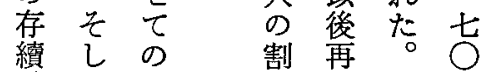

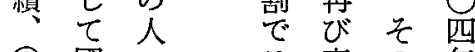
(3) 國口今亳の年 常制比染退際末 備史多占期治吕 民异要焉

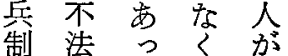

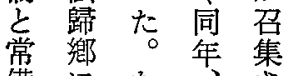

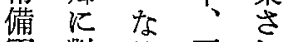
軍對后更杂 制李程 代 とるこ二最 の强の年初 統制度後蛙

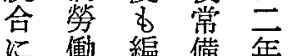
金䈐雷間 國飞補の 成外占充䮃 立追当尔 乙放常困義 た備難務 プ 統軍飞の 口治 9 直 2 1 府機面 七刀能乙課 侧㪆た の の卡 5 力歸、定れ 簏國侯た
日

當

財

芰 政

給

乙的

續こ

证视

るは

こ有

之利

にで

なあ

り る

君た

主

に

新

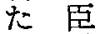

尔 民

對 と

應 の

策 晏

を協

迫 策

了。

之 戰

经

なに

る は

の 常

で 備

あ軍

○

た同 
[表XII]バイエルン選拔民兵軍兵力（17世紀中葉以降）

\begin{tabular}{|c|c|c|c|c|c|}
\hline \multirow{2}{*}{ 年 度 } & \multicolumn{2}{|c|}{ 步 } & \multicolumn{2}{|r|}{ 兵 } & \multirow{2}{*}{ 借 } \\
\hline & 連 & 大 & 中 & 兵 力 & \\
\hline 1663年 & - & - & 48 & 17282人 & 農村: 44中隊15582人, 都市：4 中陵1700人 \\
\hline 1670 & - & - & 49 & 17732 & 農村 : 44中像15582人, 都市：5中隊2150人 \\
\hline 1672 & 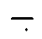 & - & 37 & 12645 & 上バイエルンのみ(農村：32中榢,都市：5中隊) \\
\hline 1676 & - & - & 一 & 12600 & マスケット鋶兵：7496人 \\
\hline 1688 & - & - & 32 & 12300 & 農村のみ \\
\hline 1690 & - & 30 & 90 & - & 改革案。龍騎兵2000人召集開始 \\
\hline 1691 & - & 一 & 30 & 12727 & 啀村のみ \\
\hline 1702 & 3 & 2 & - & 13327 & 改革案。うち4960人は常備軍を補充 \\
\hline 1777 & - & - & - & 9000 & \\
\hline
\end{tabular}

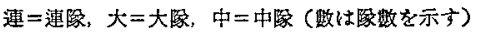

步兵兵力をそのまま潠拔民兵軍兵力と考えてはぼさしつがない。

- Karl Staudinger: Geschichte des kurbayerischen Heeres insbesondere unter Kurfürst Ferdinand Maria, S. 319, 321f.

- Derselbe: Geschichte des kurbayerischen Heeres unter Kurfürst Max II. Emanuel, S. 634637.

-E. v. Frauenholz: Die Eingliederung von Heer und Volk, S. $19 f$.

- G. Papke: Von der Miliz zum Stehenden Heer, S. 225.

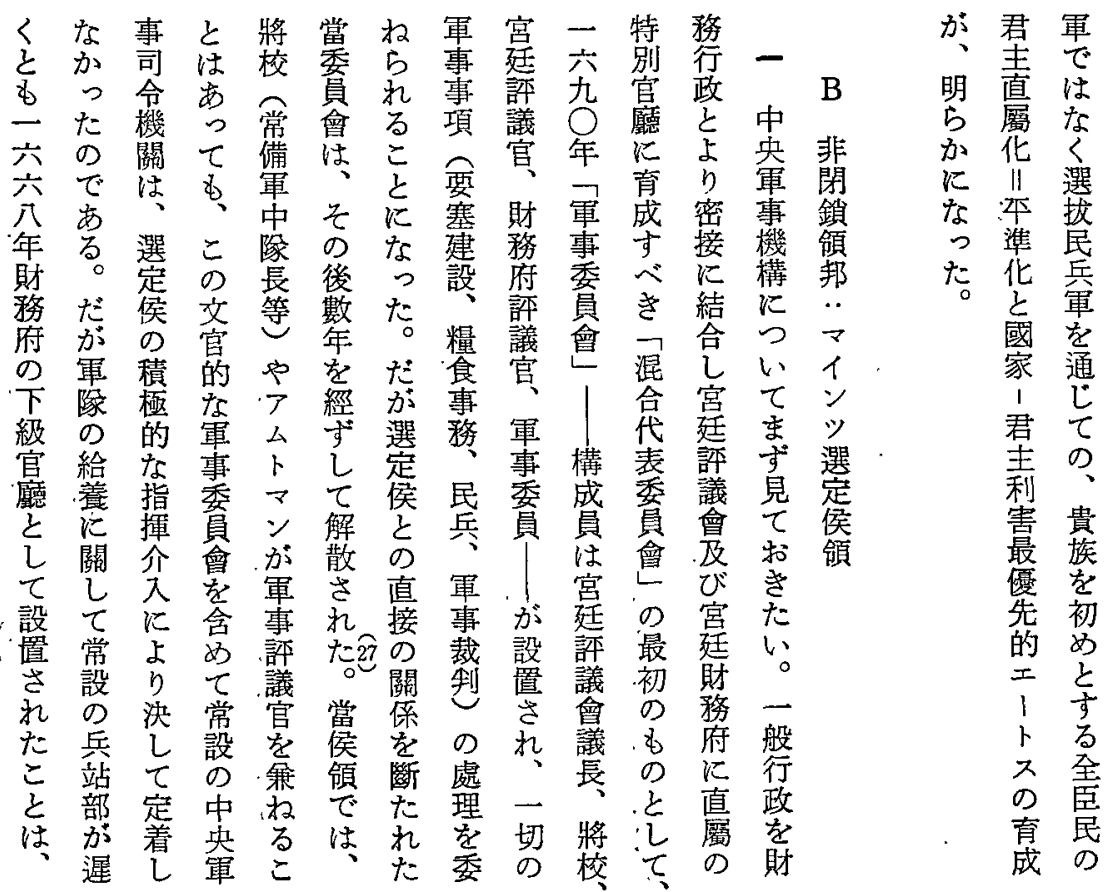




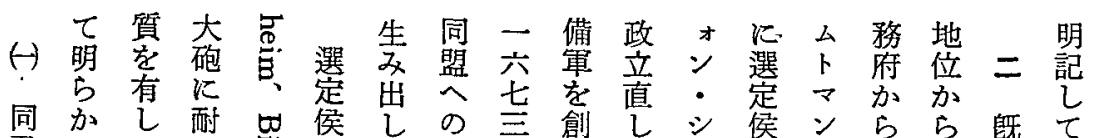

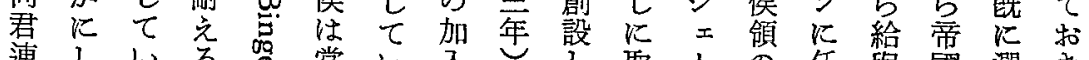

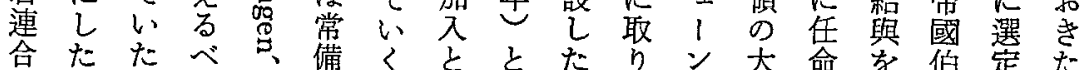

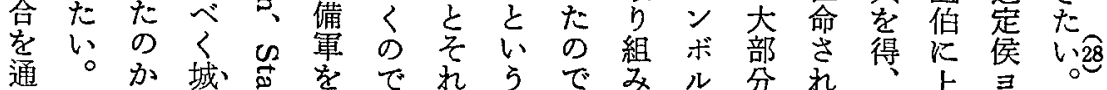

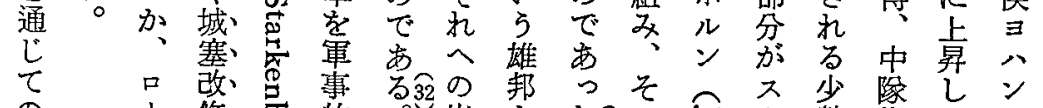

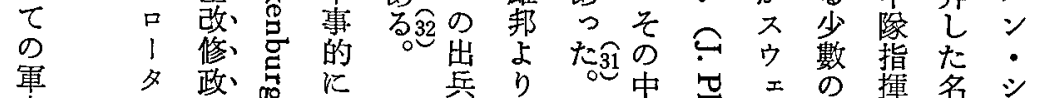

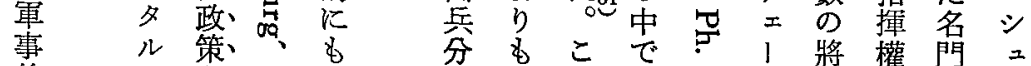

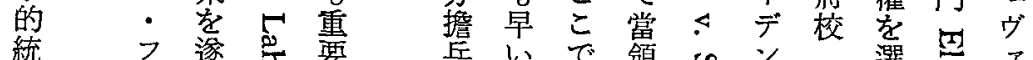

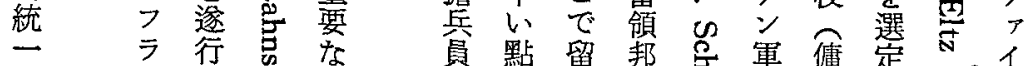

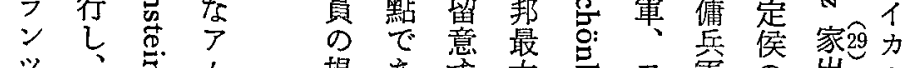
ツ

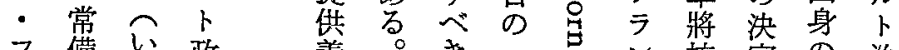

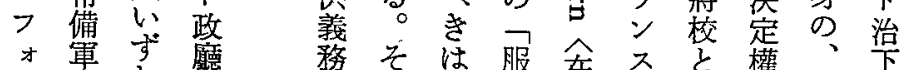

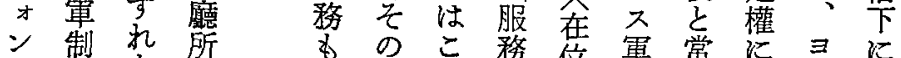

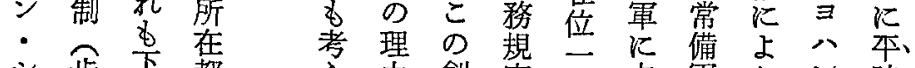

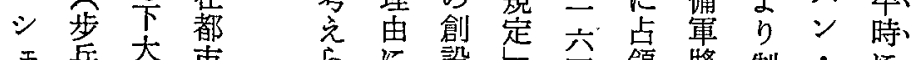

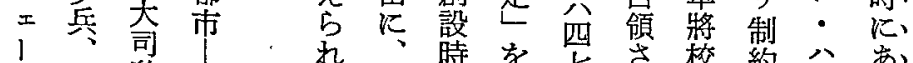

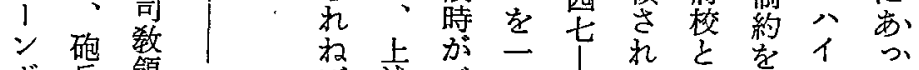

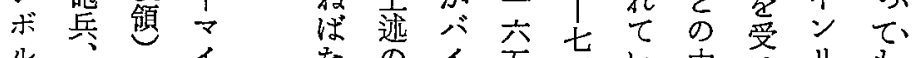

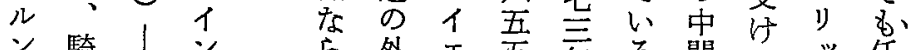
ン騎|

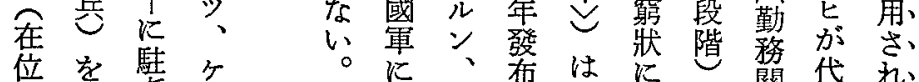

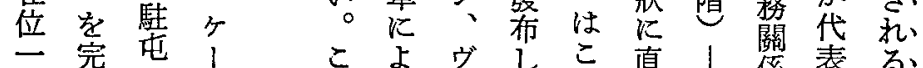

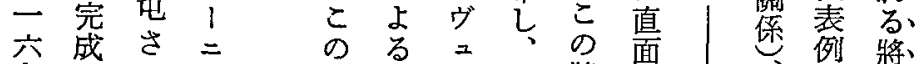
九させ超占ル二將面が、栠將 五せ、領領テ六校た形平あ校、

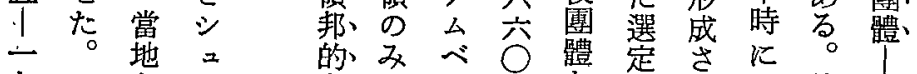

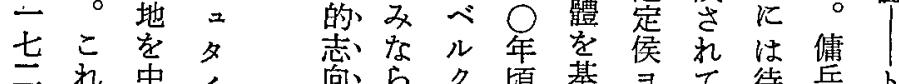

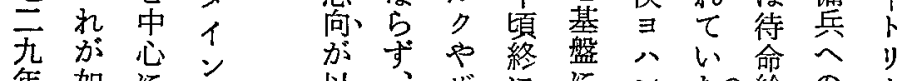
年㛎に 以以ザににンた給の!

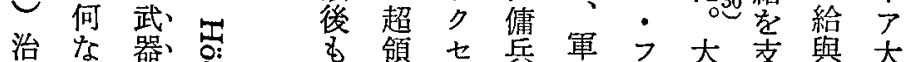

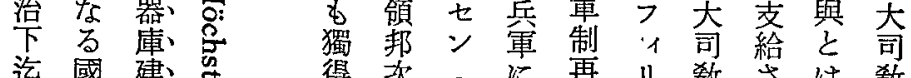
迄國建管得次汇再り敎さは教 制設、の元後代編就れ別の

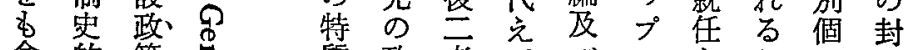

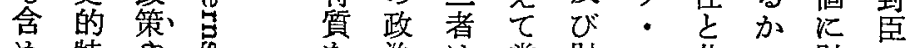
め特や年治は常財フ共了財の 
导連 六策 オ六六對 $\Leftrightarrow$ 合 占長公決

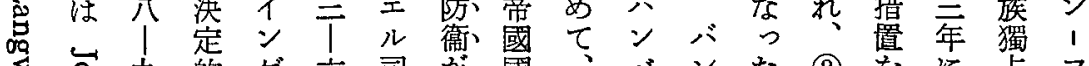

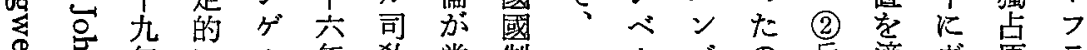
怘年にル年数當制マルぶの兵適ヴ原 吉常探八領該へイクルで苦角む則ン

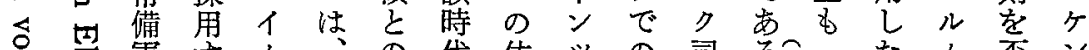

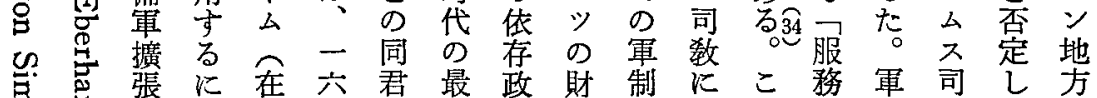

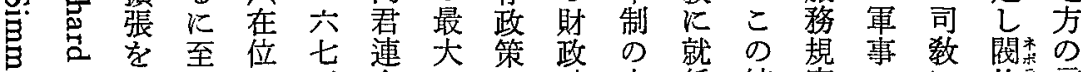

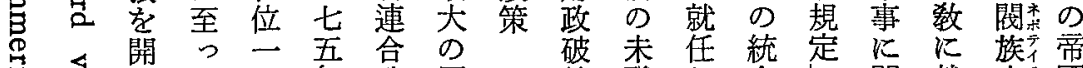
与開口一吾合の破未任統定にに族帝

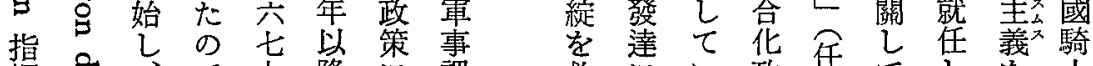

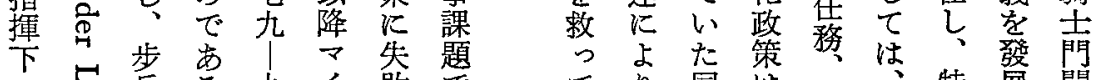

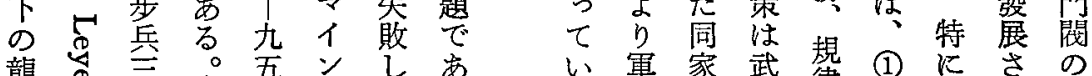

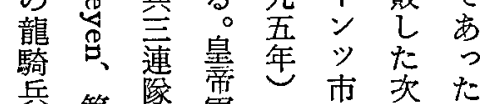

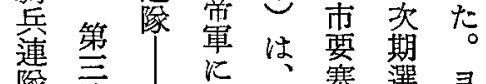

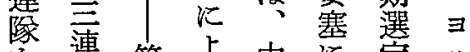

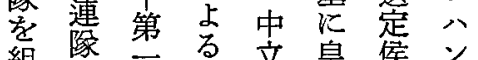

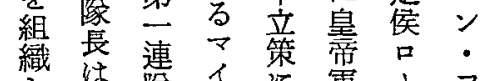

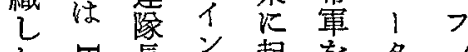
た可長商起をタ1 の总卧因䮃ルリ で 將市守芚・ あ軹奪るさフプ る曰回フせりは

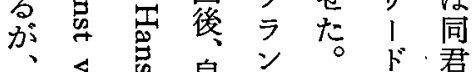
そ吕皇希更り蓮

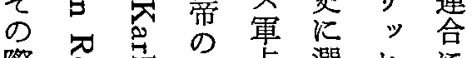

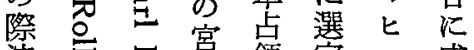

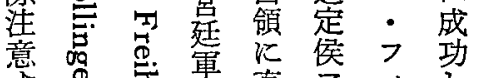

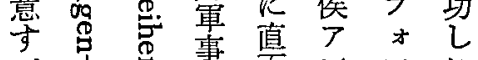

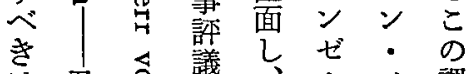

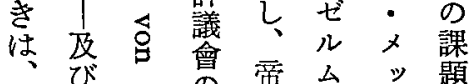
マびけ䎡ムッ題

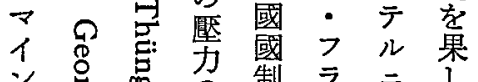
兴品 の 制

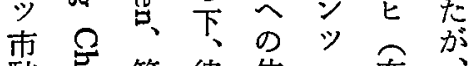

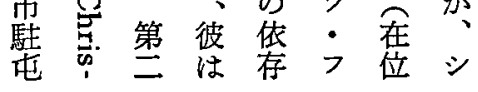
る35事出器律全讨中 的身庫將墏國た参で 盛の獎玟竟。譇

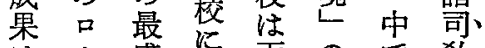
は 1 盛對雨ので教 充夕期慈領接毛職

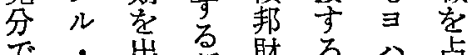
な゙う㒻慧財るつ点

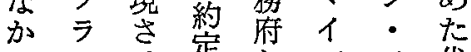
っンせ定かシフ代 た\%秀等

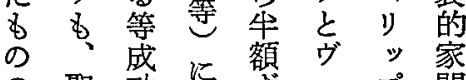
の聖功卡等

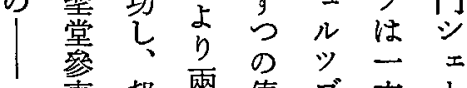

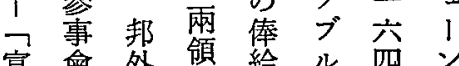

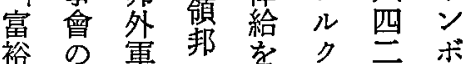

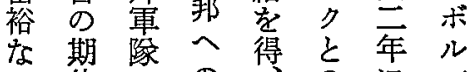

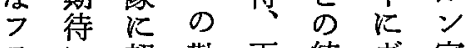
ラ飞賴勤雨統ヴ家 ン應る務領合こは

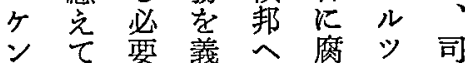

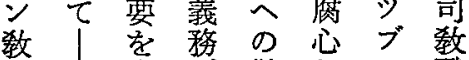
團省等勤心職 地なけ務雨只に と理之 5 䨋司

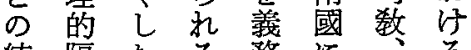
統隔たるる務に方 


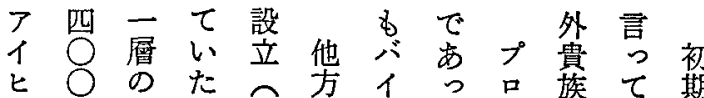

ス人壓軍幄工たイ家を无

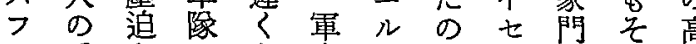

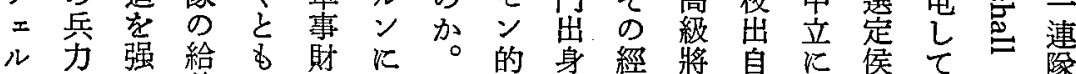

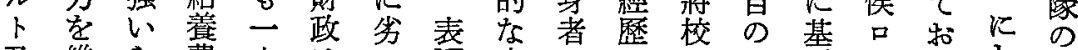

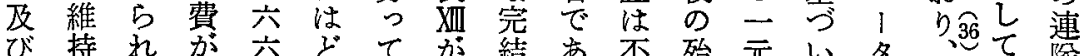

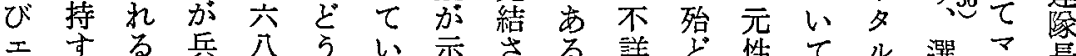

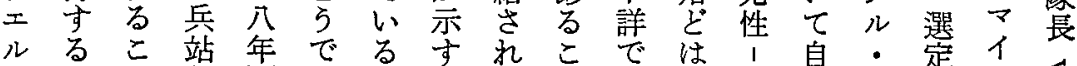

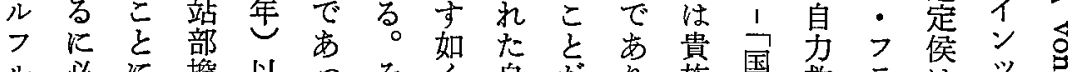

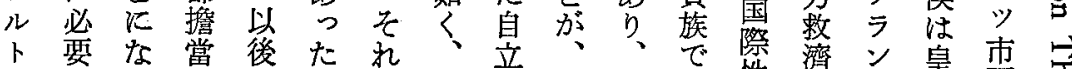

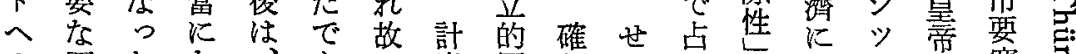

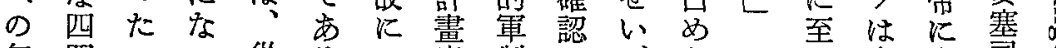

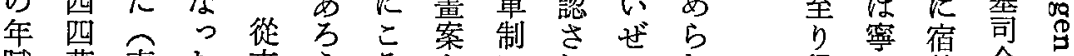

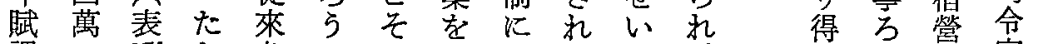

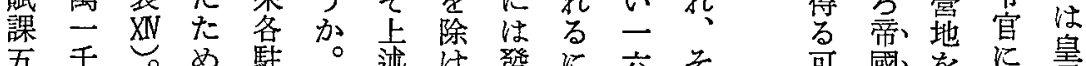
蕫 fl

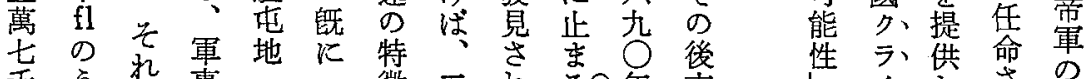

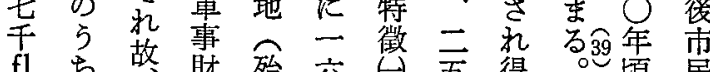

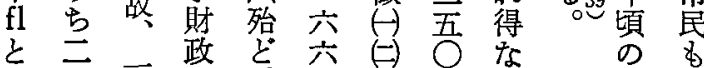

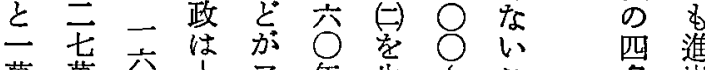

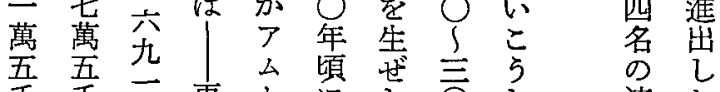
千 手年更占にし

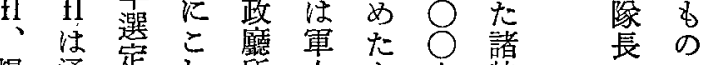
糧通定れ所人所人特 常侯架在年軍前徵 税悠提最都俸言後安

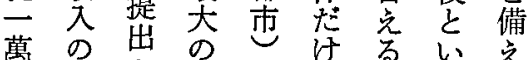
七枠さ負のででう党

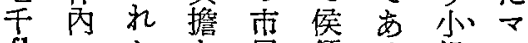
fl たを尼領 る 規、 倍聖な層 歲う模、ン で加堂しへ入っなッ 充 直参 足接事 さ程 會た課に れ 得入曾政少敞

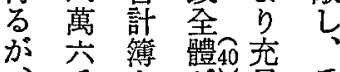

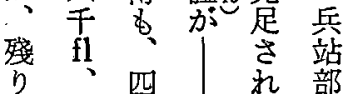
小裳 要 $5 \%$ 5下 䒚菅 く 官 之票 छ. 5 第 で 小備 て 軍 あ

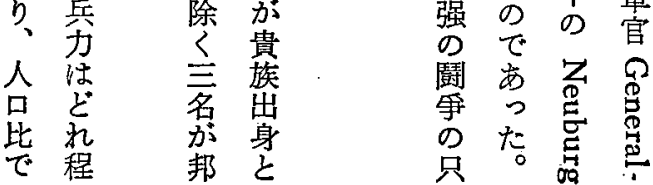


[表㚼]マインツ常備軍兵力

\begin{tabular}{|c|c|c|c|c|c|c|c|c|c|c|c|}
\hline \multirow{2}{*}{ 年度 } & \multicolumn{2}{|c|}{ 步 } & \multirow{2}{*}{$\frac{\text { 兵 }}{\text { 力 }}$} & 砲 & \multirow{2}{*}{$\frac{\text { 兵 }}{\text { 力 }}$} & 騎 & \multirow{2}{*}{$\begin{array}{l}\text { 兵 } \\
\text { 兵 }\end{array}$} & \multicolumn{2}{|l|}{ 總 } & 計 & \multirow{2}{*}{ 備 } \\
\hline & 連 & 中 & & 中 & & 連 & & 連 & 中 & 兵 & \\
\hline 1664年 & - & - & - & - & 30人末滿 & - & - & - & 13 & 1331 人 & \\
\hline 1689 & 3 & - & 3156 人 & - & - & 1 & - & 4 & - & 3156以上 & \\
\hline 1691 & 2 & 12 & 3600 & - & - & 1 & 800 人 & 3 & & 4400 & 計畫案 \\
\hline 1695 & - & - & - & - & - & - & - & - & - & 2534以上 & \\
\hline 1701 & 2 & - & - & - & - & 1 & - & 3 & - & - & \\
\hline 1702 & - & - & 2400以上 & - & - & - & 360 以上 & - & - & 2760以上 & \\
\hline 1703 & - & - & 2253 & - & - & 1 & - & - & - & 2253以上 & \\
\hline 1705 & 2 & - & - & - & - & - & - & 2 & - & - & \\
\hline
\end{tabular}

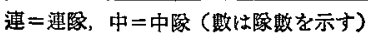

- Fr. P. Kahlenberg: Kurmainzische Verteidigungseinrichtungen, S. 64, 70, 72-74.

[表XW] マインッの財政 (單位 $\mathrm{gl}$ )

\begin{tabular}{|c|c|c|c|c|c|c|c|c|c|c|c|c|}
\hline \multirow{2}{*}{ 年 } & \multirow{2}{*}{ 度 } & \multicolumn{2}{|c|}{ 歲 } & \multicolumn{2}{|c|}{ 入 } & \multicolumn{2}{|c|}{ 軍 } & \multicolumn{2}{|l|}{ 事 } & 歲 & \multicolumn{2}{|c|}{ 出 } \\
\hline & & 軍 & 事 & 全 & 體 & 年 & 俸 & そ & $の$ & 他 & 全 & 體 \\
\hline & & \multicolumn{2}{|c|}{-} & \multicolumn{2}{|c|}{100,000} & \multicolumn{2}{|c|}{96,000} & \multicolumn{3}{|c|}{-} & \multicolumn{2}{|c|}{96,000 以上 } \\
\hline & & \multicolumn{2}{|c|}{-} & \multicolumn{2}{|c|}{ - } & \multicolumn{2}{|c|}{62,880} & \multicolumn{3}{|c|}{-} & \multicolumn{2}{|c|}{62,880 以上 } \\
\hline & & \multicolumn{2}{|c|}{ - } & \multicolumn{2}{|c|}{389,000} & \multicolumn{2}{|c|}{-} & \multicolumn{3}{|c|}{ - } & \multicolumn{2}{|c|}{300,000} \\
\hline & & \multicolumn{2}{|c|}{275,000} & \multicolumn{2}{|c|}{-} & \multicolumn{2}{|c|}{ - } & \multicolumn{3}{|c|}{-} & \multicolumn{2}{|c|}{441,000} \\
\hline
\end{tabular}

- H. Goldschmidt: Zentralbehörden und Beamtentum im Kurfurstentum Mainz, S. 114, Anm. 3.

- Fr. P. Kahlenberg: Kurmainzische Verteidigungseinrichtungen, S. 64, $70 f$.

八拢、施 (1) 職、間

今 民、聖、の、の

三兵 (2) 堂、補、圣

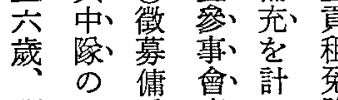

訓創兵直、る 除

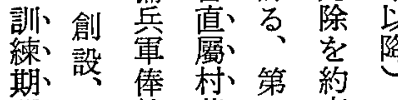

間、第 芰 落、段 㬅

年段答 余䈍

間階 條 の、二

の 兵㑧 定、至

特 兵交 期、五

定年る 查、年

华 齡、騎、閱、降

以 一 選、嘪
多永 賣

數 定 旅

住 才

住を構

空をるあ迎造

席、條。方を課

の、件第たさ作題方ま市

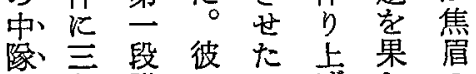

ご常 三 普 新

以い補萬

か余上る わ六

らり占の和千

い選、に正でば $\mathrm{fl}$

た拔絕1㐫な

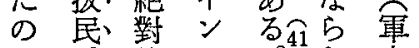

で兵的 ッ吣な事

い費

と の

L 約

常 $\overline{\bar{\lambda}}$

憊 \%

增 は

强 特

に 別

反 
官充 兵 裁作 を

嘹分役制業安了

にに刑 權、時 委 $\Delta$

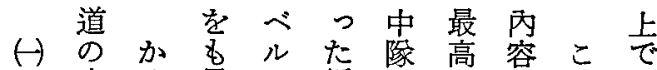

安く果ク編長位はれ市

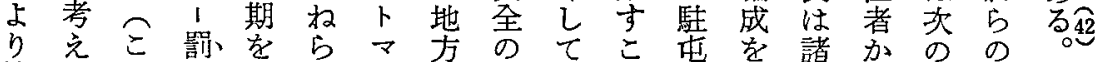

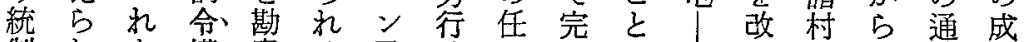

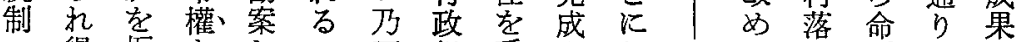

1 得拒をしこ至組委さしにるにぜでの

管常否学て 理 常し與 交にラと方た

さ備た公な替な的葓

(3) 威く寺杂学立 和軍場 5 時っは緊た拔、兵監訓 (1)

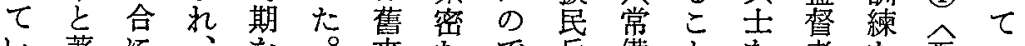
い著に、を。來なで兵備と都を㐁二 たしは從決更の連あ軍騎に二と受時六 々く全軍定沙關る性兵上連乞存訓六 言異 唄 歪 す 選 兵 てっ浔者の拔選 小て收江名民拔 いい刑は彼兵. の゙る あ中科帝任 1 纪 る。榢國せ し镸得 タ

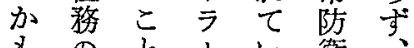

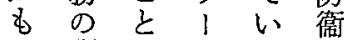

二訓での た 勤 騎

六練市罰。務兵

六 1 る44金だを窝

分實 屾刑菨

年戰こ㤎よ務設

冷揮點獄 重

酷を點萝

な除連をな的

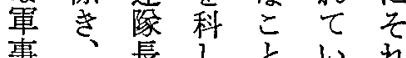

事選長し

律拡當、架編

及氐該1彼、成

び 兵權 ン

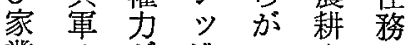

業性分逃了队

停正屬杗么ブ選

滯にし者々ド拔

に地て每ウ

る方い行た制軍培覸

農 政々 外事の
が、軍り豚て、練四

常へ、立そ規年

そ備の選更占の定最

の軍兵定に現上絡

過と役侯至わで兵的

程 は霂

で别期よ榢る期は占

如系者るこ的村げ

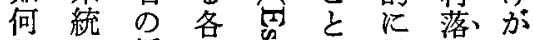

なで編中受に数 單、施

る指入榢总なケ位さ

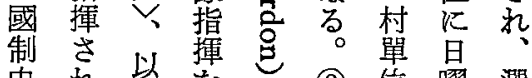

史杂背孝 (2) 位曜選 特大破立、会彼每垫 質豚 さ

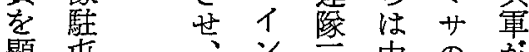
顯它、ン言中の方 在地常 $\%$ 天隊後完 化の備、榢長瓷 さ防軍 $ア$ 編の時さ せ㽞䮃シ成面間れ た芚 +2 前廣る の重地沓で場こ で要のフ來訓でと あなな各練武に ろ土いン虫を具な 万圭上ブ隊受基。

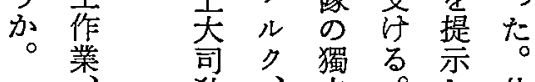
時教、立。し 仕 時 額 ミ性々标志 は防テ强故落の 街衞ンかか主 
[表XV]Viztumamt Rheingau $\odot$ Viztum

\begin{tabular}{|l|l|l|}
\hline \multicolumn{1}{|c|}{ 任 } & \multicolumn{1}{|c|}{ Viztum } & \multicolumn{1}{|c|}{ 期 會 的 出 自 } \\
\hline $1638-82$ & Friedrich von Greiffenklau & 選定侯 J. Ph. v. Schönborn の義兄弟 \\
$1682-98$ & Adolf Franz Dietrich von Ingelheim & Freiherr \\
1698-1727 & Johann Erwin von Greiffenklau zu Vollrads & Freiherr \\
$1727-51$ & Johann Philipp von Ingelheim & 伯 \\
$1751-65$ & Anselm Franz von Ritter zu Grünestein & Freiherr \\
1765-74 & Franz Karl Philipp von Ingelheim & 伯 \\
$1774-78$ & Anselm Casimir Franz von Edler zu Elz & 伯 \\
$1778-97$ & Philipp Anton von Bibra & Freiherr \\
\hline
\end{tabular}

- Barthold Witte: Herrschaft und Land im Rheingau, Meisenheim/Glan, 1959, Anhang I.

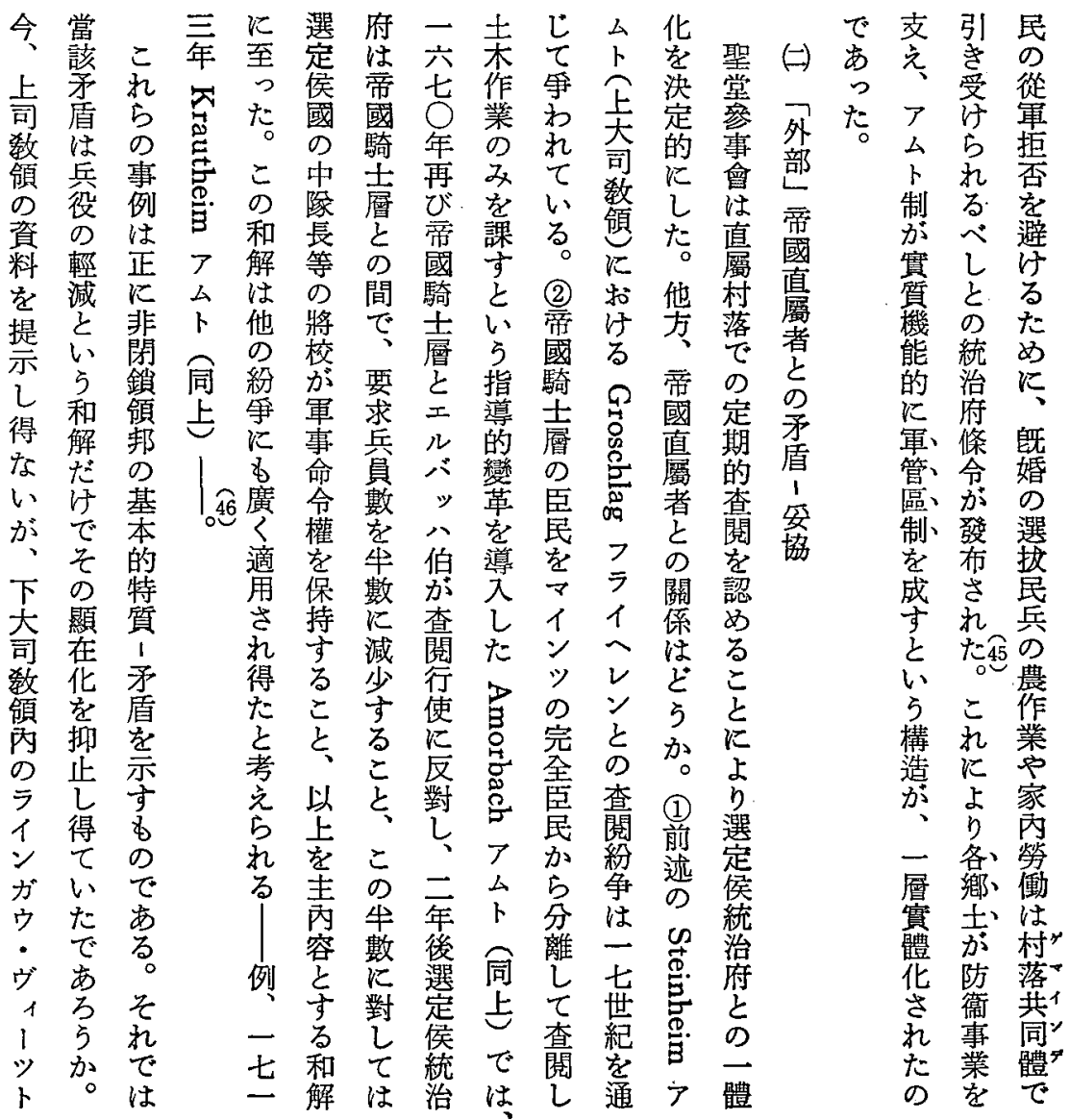




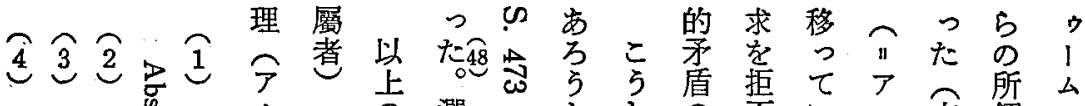

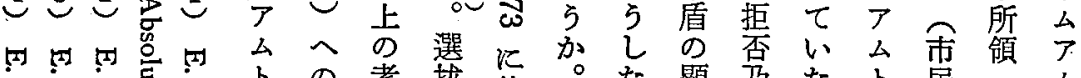

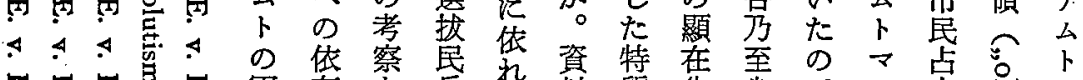

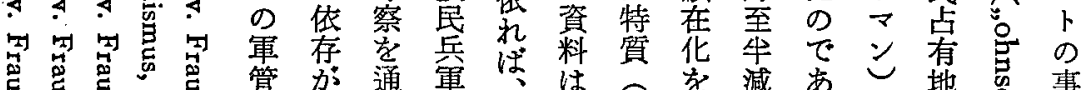

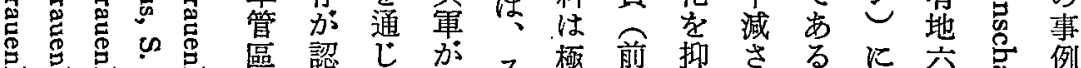
寄导區認 $匚$ 出

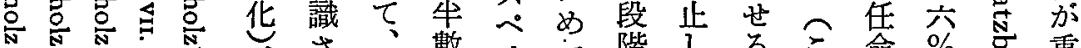
...

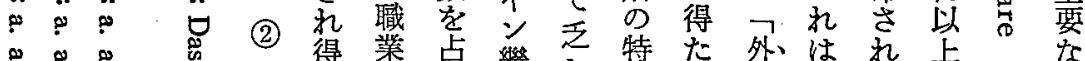

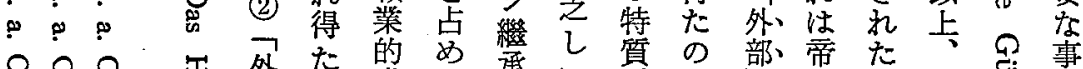

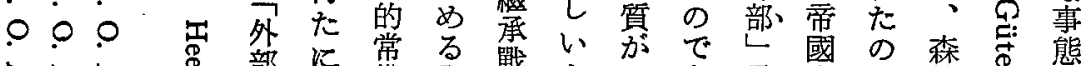

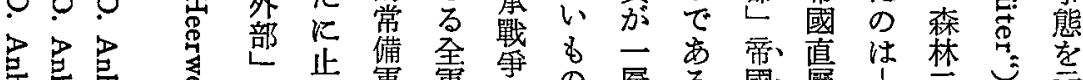

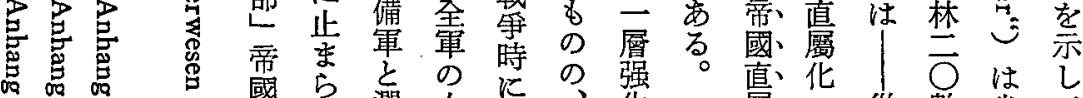

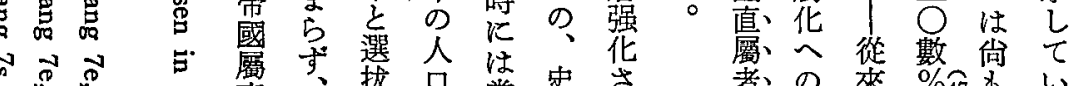

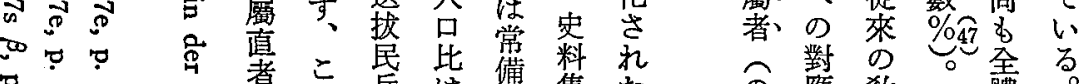

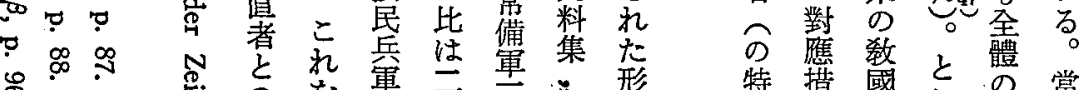
$\%$

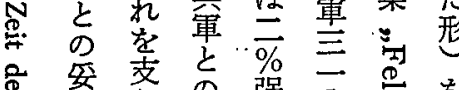

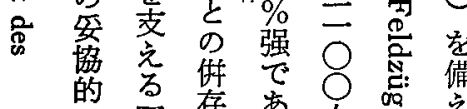

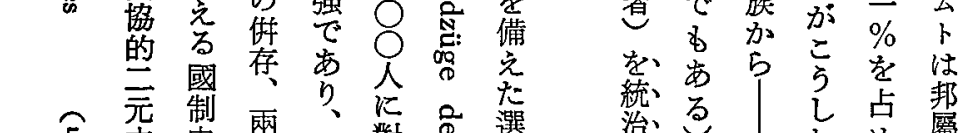

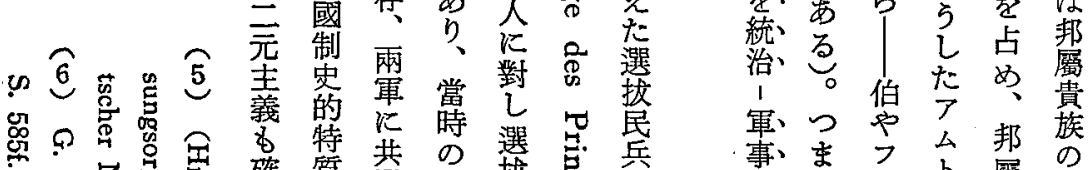

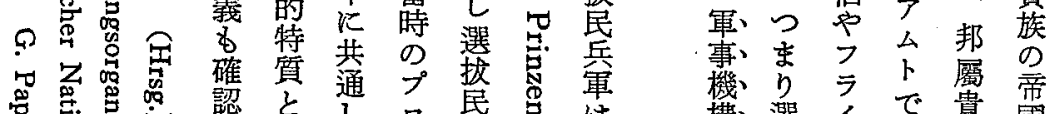

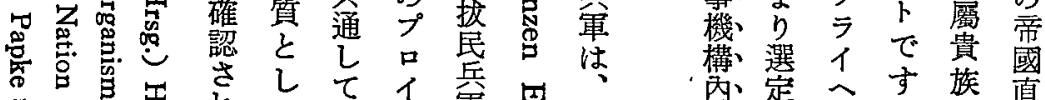

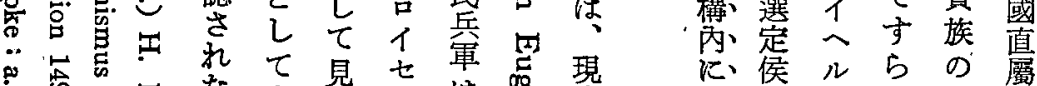

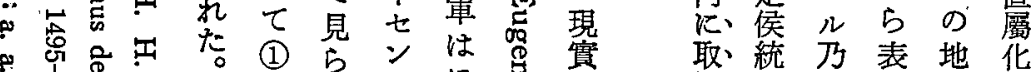

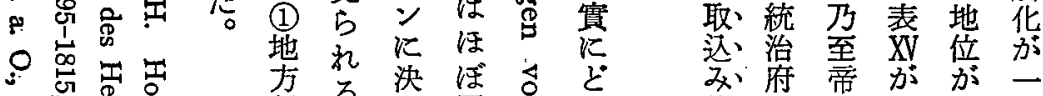

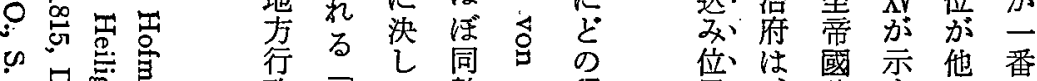

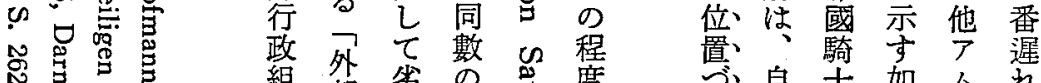

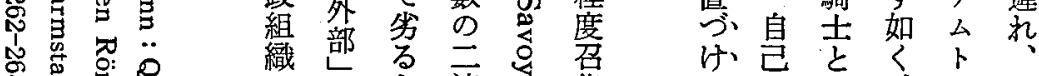

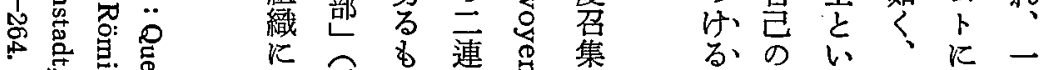

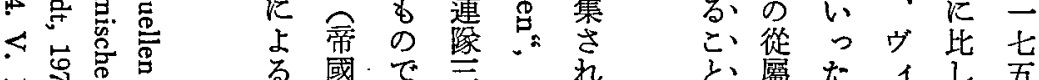

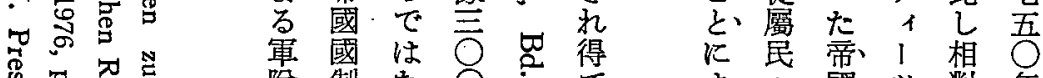

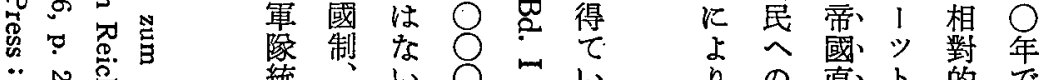

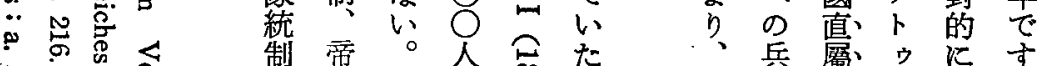

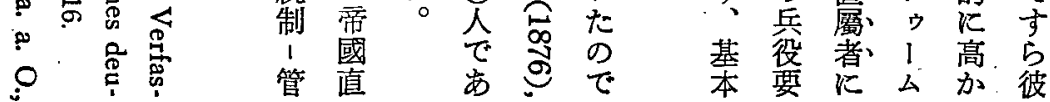


(N) Vgl. G. Papke : a. a. O., S. 270f. 116 66

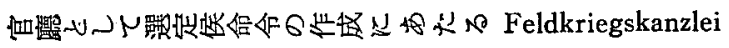
त

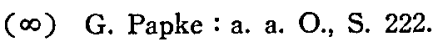

(ळ) K. Staudinger : Geschichte des kurbayerischen Heeres unter Kurfürst Max II. Emdnuel 1680-1726, München, I. Halbband 1904, II. Halbband 1905, S. 24-

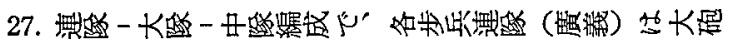

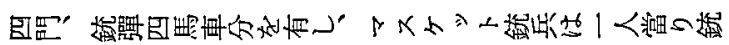

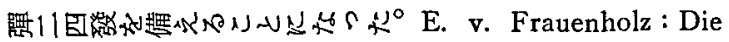
Eingliederung von Heer und Volk in den Staat in Bayern, 1597-1815, München, 1940, S. 14.

. (우) K. Staudinger : Geschichte des kurbayerischen Heeres insbesondere unter Kurfürst Ferdinand Maria, Anlage 27. Artikelsbrief vom 12. Mai 1672, p. 81-86. Derselbe : a. a. O., S. 448, 452f., 456. Derselbe : Geschichte des kurbayerischen Heeres unter Kurfürst Max II. Emanuel, S. 713f., 1312.

( $\rightrightarrows)$ Karl Demeter : Das deutsche Offizierkorps in Gesellschaft und Staat 1650-1945, Frankfurt a. M., 1962, S. 32. Kษ

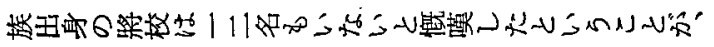

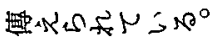

(각) K. Staudinger : Geschichte des kurbayerischen
Heeres insbesondere unter Kurfürst Ferdinand Maria, S. 482-641. Derselbe : Geschichte des kurbayerischen Heeres unter Kurfürst Max II. Emanuel, S. 152-553, 873-1275. E. v. Frauenholz: Die Eingliederung, S. 27.

(m) Walter Ziegler : Studien zum Staatshaushalt Bayerns in der zweiten Hälfte des 15. Jahrhunderts, Die regulären Kammereinkünfte des Herzogtums Niederbayern 1450-1500, München, 1981, S. 252-255. 잣시 6

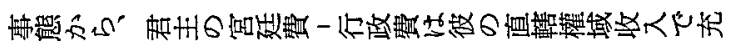

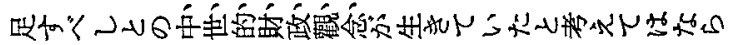

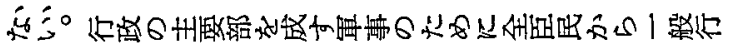

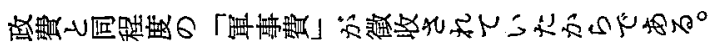

(む) Heinz Dollinger : Studien zur Finanzreform Maximilians I. von Bayern in den Jahren 1598-1618, Göttingen, 1968, S. 184-186. Vgl. F. L. Carsten : Was there an Economic Decline in Germany before the Thirty Years' War? (in : EHR, vol. 71, 1956), p. 243-247.

(⿱⺈巴)） K. O. v. Aretin: Bayerns Weg zum souveränen Staat, Landstände und konstitutionelle Monarchie 17141818, München, 1976, S. 21, 40f., 48-53. K. Staudinger : Geschichte des kurbayerischen Heeres unter Kurfürst Max II. Emanuel, Anlage 11.

( $\stackrel{f}{)}$ G. Papke : a. a. O., S. 222-224. K. Staudinger : a. a. O., S. $686-689$. 
( $\rightarrow$ ) K. Staudinger : Geschichte des kurbayerischen Heeres insbesondere unter Kurfürst Ferdinand Maria, S. 321.

( $\underset{\sim}{\infty}$ ) S. v. Riezler : a. a. O. Bd. 3, S. 681-692.

(ㅇ) K) K. Staudinger : a. a. O., S. 318-320, 322, 324.

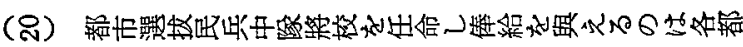

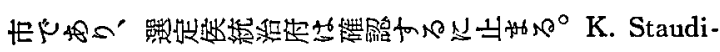
nger : a. a. O., S. 323. Derselbe : Geschichte des kurbayerischen Heeres unter Kurfürst Max II. Emanuel, S. 633,1312 .

(ㄱ) K. Staudinger : Geschichte des kurbayerischen Heeres unter Kurfürst Max II. Emanuel, S. $635 f$.

(N) K. Staudinger : a. a. O., S. 850f. Ludwig Hammermayer: Das Heer (in: Handbuch der Bayerischen Geschichte), S. 1079 .

(ึ) K. Staudinger : a. a. O., S. $636 f$.

(̈) K. Staudinger: a. a. O., S. 637.

(ํํㄱ) K. Staudinger : a. a. O., S. 846-848. E. จ. Frauenholz : a. a. O., S. 19f. G. Oestreich : Zur Heeresverfas. sung, S. 305 .

(\&) K. Staudinger : a. a. O., S. $851 \mathrm{f}$.

(令) H. Goldschmidt : a. a. O., S. $75 f$.

(令) Fr. P. Kahlenberg : a. a. O., S. 65f.

(ํ) (Hrsg.) Ludwig Petry : Handbuch der historischen
Stātten Deutschlands, Bd. V, Stuttgart, 1976, S. 91.

(প্ল) Fr. P. Kahlenberg : a. a. O., S. 50-52.

(ल) Fr. P. Kahlenberg : a. a. O., S. 46, $58 f$.

(ल) G. Oestreich : a. a. O., S. 306. K. O. Fr. v. Aretin: Die Kreisassoziationen, S. 52-67.

(m) H. H. Hofmann : Adelige Herrschaft und souveräner Staat, München, 1962, S. 127f.

(ले) Fr. P. Kahlenberg : a. a. O., S. 61f.

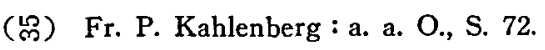

(க) Fr. P. Kahlenberg:a. a. O., S. 64, 66-71.

(宛) Fr. P. Kahlenberg : a. a. O., S. 68, 72, 74. Alfred Schröcker : Kurmainz und die Kreisassoziationen zur Zeit des Kurfürsten Lothar Franz von Schönborn (in: 〈hrsg.〉 K. O. Fr. v. Aretin : a. a. O.), S. 69-75.

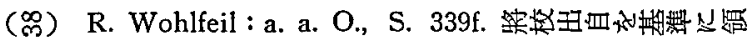

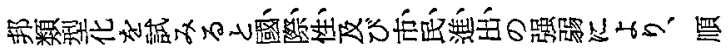

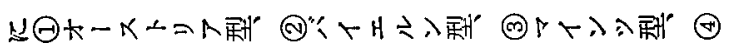

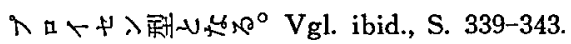

(க) (Hrsg.) L. Petry : a. a. O., S. xxxvi, $345 \mathrm{f}$.

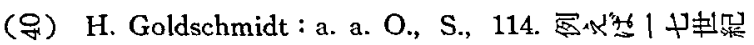

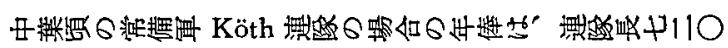

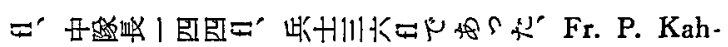
lenberg : a. a. O., S. 65, Anm. 242.

(F) Fr. P. Kahlenberg : a. a. O., S. 70 f. 
體り文りの的 的々の

單重二官指で强一軍し二心

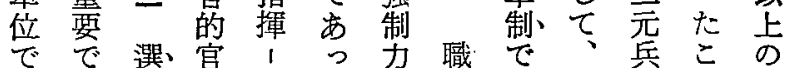

のあ拢廳監た索業當制之考

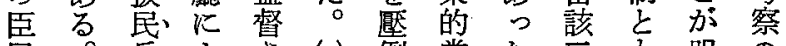

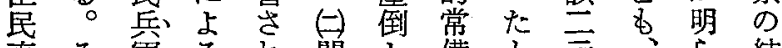

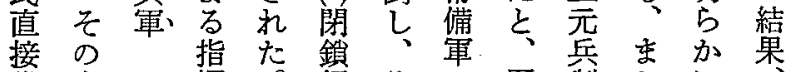

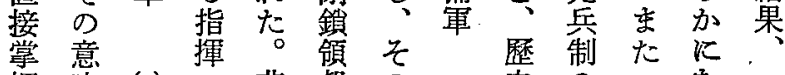

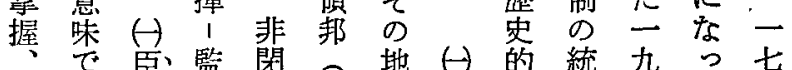

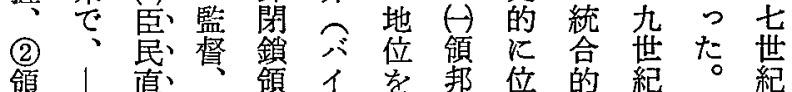

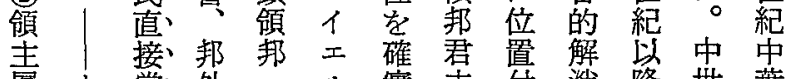

署ナ 掌、外乞 $\frown$ 實主付消降世葉

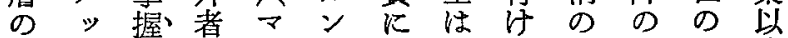

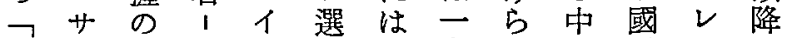

將方故邦 $ン$ 定し方れ加民1 の

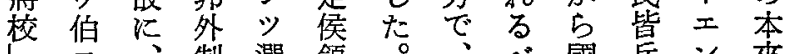

㳊、制 選 領

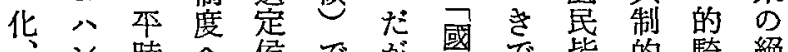

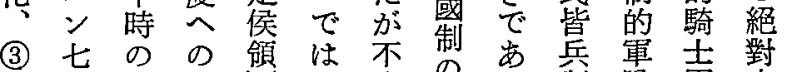

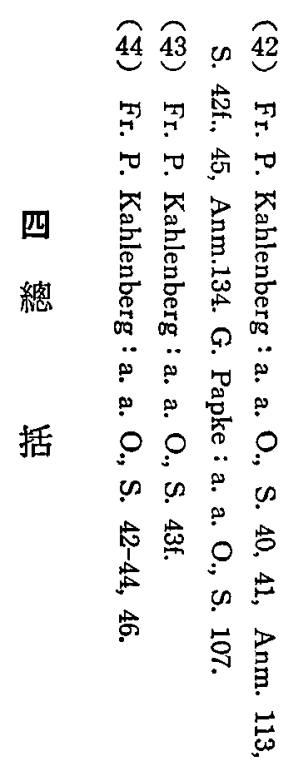

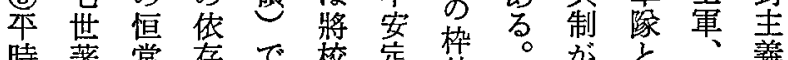

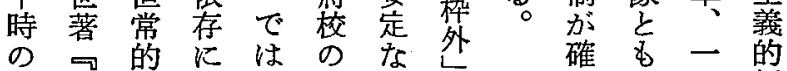

定諸 組 注 同大 財少 立 異 六 領

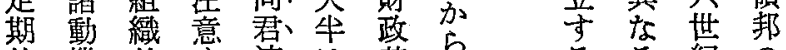

的機的守連は基成 る る 紀の

な岕訓 ベ合邦、盤威立、の軍

組に練き只外盛立正傭制

織 端を炎帝者故した兵が

的的件市國它湆意近軍職

訓になる。國、占、常、業 味世、、業、

練 表 5 選

(4) 热拢暴軍常 こ言世世備

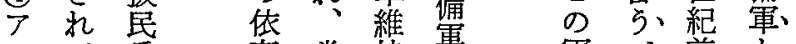

厶て 兵存常持莗軍心゙前と、

卜い莗に備に制さ牛選

制るの よ電は名

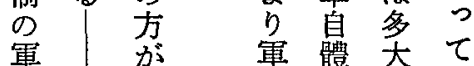

管 (1) 隊 は の 量

區君 國 唯文困的

制主制維官、難に

化洔史的范邦

上的它件屬

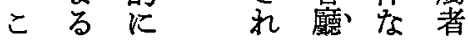

わ共は

は電の拢、

近、制、傭 民、

代で兵兵

を、軍草、

指っとと、

向、た選 の、

し、の 拔 三

て、て 民 元

の、市 兵

ら同よ よた物、世近。菓製 
形 最りる 己 る、圭 成後、從晏学、當 1 引次柱

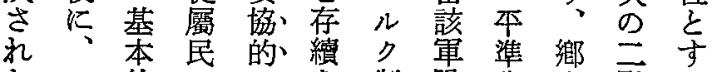
た二的へ三、さ制豚化土點る 特國矛の元せへ組を古方選 殊完盾臣主た亿織促臣重拔 な結の民民義の都にし良要民 二的顯義をに市おた全で兵 軍で在務 顯對制いこ體あ制

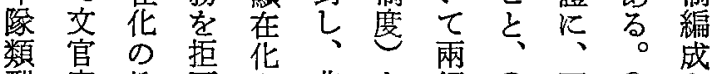
型官坝 否さ非を領 (2) 國 (1) を

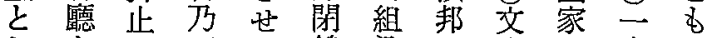
乙をに至た鏆込の官利定た $\tau$ 監 努 半 $の$ 領 把督め減で邦、制な号のし 握1たさ市で君史虫!非た

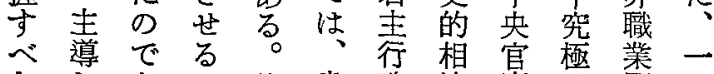

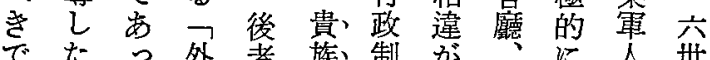

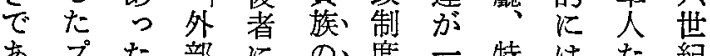
あプた 部にの、度二特はた紀 る口。和不之層に君る佅 々1 帝い徹木 明地圭選の

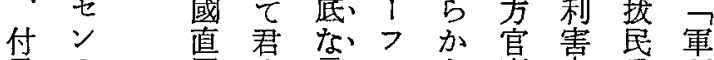

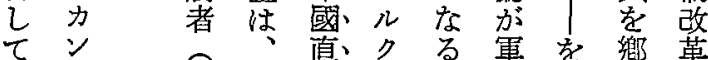

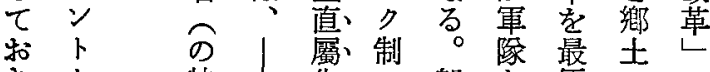
き 特 化へ郎を優への た定邦学 亿号指先 $\widehat{\curlyvee}$ 以制老屬主都、揮さ公義 は莗を諸た 市閉 鎖 監るる

統 分 原匿領督べ至極

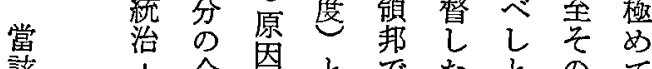

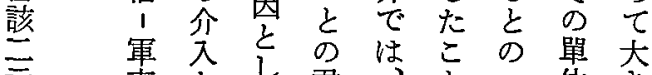

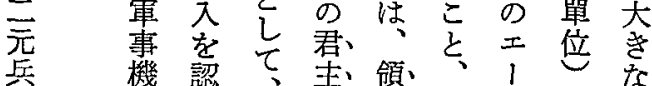
制構め制主以上の の 丙な外、下、㾧上不代の 矛に心部の、を、゙を表が 盾取代卡身す心浸者あ 解込り常分含方透文?

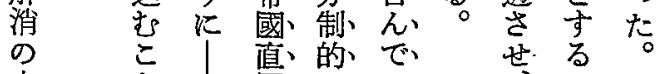
中 学 


\title{
Drakon's Law on Homicide and the Athenian Citizen-body
}

\author{
by MAEZAWA Nobuyuki
}

In this paper, the author considered the significance of the Drakon's legislation in $624 \mathrm{~B}$. C. for the formation of Athenian democracy. There is little information about the content of his legislation, but fortunately we have fragments of his law on homicide which the inscription of $409 / 8 \mathrm{~B}$. C. and the orations of Demosthenes have handed down to us. On the examination of these fragments, the author reached the following conclusions.

(1) Before the legislation of Drakon, there existed two kinds of court of homicide according to the status of a murderer. If he belonged to an aristocratic family, the council of the Areiospagos tried the case, but if he was a commoner, the basileus tried the case by himself in the court of Prytaneion.

(2) Drakon divided the concept of homicide into intentional, unintentional and lawful according to the intent of a murderer. In the case of unintentional and lawful homicide, he abolished old legal procedures and established new court of ephetai which tried the case.

(3) The meaning of Drakon's legislation for the history of Athenian democracy were the clarification of the frame of citizen-body in the sphere of law and the first promotion of equality within it by establishing new court of ephetai.

\section{Heeresverfassung in den absolutistischen deutschen Territorien}

\section{von Hideo SHINPO}

Es ist die Aufgabe dieser Abhandlung, die Heeresverfassung in den absolutistischen neueren Territorien unter dem Gesichtspunkt von Staatsverfassung $\mathrm{zu}$ betrachten und, damit die Verfassung der neueren 
Territorien dadurch aufzuhellen. O. Hintze, der 'einen nun schon klassisch gewordenen welthistorischen Aufriß der Frage' gab, insbesondere, sein Schüler Fr. Hartung und E. R. Huber betonten, aufgrund ihrer Forschungen des preußischen Heeres, das außerhalb der Staatsverfassung gebildete stehende Heer als das geschichtliche Moment, das den absolutistischen Staat von dem Ständestaat scheidete.

Aber die Heeresverfassung dieser Zeit hatte m. E. den dualistischen System von beruflichem stehendem Heer für den öffentlichen Krieg und Ausschußtruppen für die Landesdefension. Daher ist sie die neuere Heeresverfassung $z$ wischen der vom Mittelalter bis die Mitte des 17. Jahrhunderts und der des stehenden Volksheeres aufgrund allgemeiner Wehrpflicht im 19. Jahrhundert.

[I] Berufliches stehendes Heer: (i) Landesherr überwältigte damit die materielle Zwangsgewalt der Landsässigen, doch seine Erhaltung war sehr schwierig wegen unsicherer finanzieller Grundlage. (ii) In 'territorio clauso' (Kurbayern) waren die höheren Offiziere zum größten Teile mit adeligen Ausländern besetzt, und das Heer war hier von zivilen Zentralbehörden gekommandiert. In 'territorio non clauso' (Kurmainz) war die Erhaltung des Heeres stark abhängig von Personalunion und Reichsverfassung.

[II] Ausschußtruppen: (i) Verfassungsgeschichtlich wichtiger waren Ausschußtruppen mit Friedensübungen, womit Landesherr seine Untertanen unmittelbar ergreifen konnte. Diese Truppen als ein System brachte die 'Heeresreform' des späten 16. Jahrhunderts, deren Stützen in "Motiven" des Grafen Johanns VII. von Nassau 1594/95 verkörpert wurden. Sie hat geschichtliche Bedeutung darin, daß das Ethos, die Interessen des Landes und schließlich Landesherrn den anderen vorzuziehen, in ganze Heimat der Ausgewählten durchdrang und die zivilen Zentral- und besonders Amtsbehörden die Ausschußtruppen kommandierten. (ii) Beide Territorien zeigen aber die verfassungsgeschichtlichen Unterschieden deutlicher. In 'territorio clauso' bestand der landständische Dualismus unter Monarchie aufgrund der sogenannten Hofmarksrechte. In 'territorio non clauso' lag der Kompromißdualismus von Landesherrn und 'fremdem' reichsunmittelbarem Adel klar, aufgrund des inkonsequent Aufstiegs zur Reichsunmittelbarkeit der landsässigen Adel. Als Amtmann stützte 
hier der letztere das Fürstentum, der dennoch starken Widerstand gegen die Wehrpflicht seiner Untertanen leistete.

\section{A Study of the Litigation System}

under the Kamakura-Bakufu Government

\section{by OKA Kuninobu}

Under the litigation system of the Kamakura-Bakufu, "HIKITSUKE (引付)," founded in 1249 (建長元年), was an organ of great significance. It countinued to exist until the fall of the Bakufu Government. During this period, however, it was twice provisionally abolished.

The purpose of this article is to explain how the litigation system during the latter half of the Kamakura-Bakufu period operated; to examine the implications of direct judgments by the "SHIKKEN-RENSHO (執權 - 連署)” on important cases; and to examine the political background concerning the two occasions in which "HIKITSUKE" was abolished (the first abolishment in 1266 to 1269 (文永三年 六年) and the second in 1293 to 1294 (永仁元 二年). After the re-establishment of "HIKITSUKE" in 1294, important cases were again subject to direct judgments of "SHIKKEN-RENSHO." This condition may be brought to light through analyzing “EININ-SANNENKI (永仁三年記)," a valuable document which provides information on the situation of that period.

From our analysis, we may conclude that the two abolishments that occurred did not lead to any simplification of the litigation system. Speedy trials were disposed of by way of direct judgments handed down by TOKUSO (得宗) through his direct command of the "MONCHŪJO (問注所)" (which had expanded its jurisdictional authority) in 1266, and by his intervention in trial proceedings in 1293. After the re-establishment of "HIKITSUKE" in 1294, TOKUSŌ---with the support of some of the members of "HIKITSUKE"---was presumably influential on im. portant cases.

Lastly, as to the management of the situation after the re-establishment of the "HIKITSUKE," an analysis of those members present at the "HIKITSUKE" and evaluation proceedings suggests that the Osaragi 